\title{
AVALIAÇÃO DA VARIABILIDADE GENÉTICA EM Musa spp. UTILIZANDO MARCADORES MICROSSATÉLITES
}

\author{
SILVANA APARECIDA CRESTE DIAS DE SOUZA
}

\begin{abstract}
Tese apresentada à Escola Superior de Agricultura “Luiz de Queiroz", Universidade de São Paulo, para obtenção do título de Doutor em Agronomia, Área de Concentração: Genética e Melhoramento de Plantas.
\end{abstract}

PIRACICABA

Estado de São Paulo - Brasil

Fevereiro - 2002 


\title{
AVALIAÇÃO DA VARIABILIDADE GENÉTICA EM Musa spp. UTILIZANDO MARCADORES MICROSSATÉLITES
}

\author{
SILVANA APARECIDA CRESTE DIAS DE SOUZA \\ Engenheiro Agrônomo
}

Orientador: Prof. Dr. AUGUSTO TULMANN NETO

Co-orientador: Prof. Dr. ANTONIO VARGAS DE OLIVEIRA FIGUEIRA

\begin{abstract}
Tese apresentada à Escola Superior de Agricultura "Luiz de Queiroz", Universidade de São Paulo, para obtenção do título de Doutor em Agronomia, Área de Concentração: Genética e Melhoramento de Plantas.
\end{abstract}

PIRACICABA

Estado de São Paulo - Brasil

Fevereiro - 2002 
Dados Internacionais de Catalogação na Publicação (CIP) DIVISÃO DE BIBLIOTECA E DOCUMENTAÇÃO - ESALQ/USP

Souza, Silvana Aparecida Creste Dias de Avaliação da variabilidade genética em Musa spp. utilizando marcadores microssatélites / Silvana Aparecida Creste Dias de Souza. - - Piracicaba, 2002. 86 p. : il.

Tese (doutorado) - Escola Superior de Agricultura Luiz de Queiroz, 2002. Bibliografia.

1. Banana 2. Marcador genético 3. Melhoramento genético vegetal 4. Variação genética em plantas I. Título

CDD 634.772

\section{"Permitida a cópia total ou parcial deste documento, desde que citada a fonte - $\mathrm{O}$ autor"}


A Deus, essência da minha vida, pelo talento e direção a mim concedidos na realização deste trabalho

\section{DEDICO}

Ao meu marido Paulo e ao meu filho João Victor, pelo amor, incentivo e compreensão

\section{OFEREÇO}

"Dá instrução ao sábio, e ele se fará mais sábio, ensina ao justo e ele crescerá em entendimento" (Provérbios, 9:9) 


\section{AGRADECIMENTOS}

Ao CNPq, pelo apoio financeiro na concessão da bolsa de doutorado;

À FAPESP, pelo financiamento do projeto;

Ao prof. Dr. Augusto Tulmann Neto, que por acreditar na minha capacidade, me ofereceu a oportunidade e as condições para desenvolver este trabalho;

Ao prof. Dr. Antonio Figueira, que me ungiu com todo conhecimento, profissionalismo e competência, dando-me exemplos de garra e força de vontade;

Ao Sebastião de Oliveira e Silva, da Embrapa Mandioca e Fruticultura, pela doação do material vegetal,

Ao amigo Alexandre Coelho, pelo auxílio na análise dos dados;

Ao prof. Dr. Roland Vencovsky, por ter me honrado com suas valiosas sugestões na análise e interpretação dos dados;

Aos professores do Departamento de Genética, pela minha formação acadêmica,

Aos funcionários do departamento de Genética da ESALQ/USP, pelo carinho e amizade,

Aos funcionários do laboratório de Melhoramento de Plantas, do CENA/USP, pela ajuda e amizade,

À prof. Dra. Maria Tereza Vitral de Carvalho Derbyshire, por todos os favores concedidos,

Aos amigos Rodrigo Rocha Latado e Rafael Moyses Alves, pelas trocas de experiências durante a condução dos experimentos;

Aos amigos Carlos Rogério de Souza Silva e Cristiane Cristina Borges, pela colaboração, convivência e amizade; 
Ao João Geraldo Brancalion, do laboratório de informática do CENA, por toda a ajuda prestada,

Aos meus pais, por todas as vezes que renunciaram a si mesmos em prol de minha formação,

Aos meus irmãos, pelo privilégio de tê-los como irmãos,

Ao meu marido, Paulo, por ter me ensinado que os caminhos da vitória são percorridos com amor, determinação, coragem e humildade,

Ao meu filho, João Victor, por ter me amado de forma incondicional, mesmo quando não fui o melhor exemplo de mãe,

À minha sogra, Elsa, que sempre me socorreu nos momentos de grandes apertos; Aos colegas do curso de pós-graduação pelo convívio e troca de conhecimentos,

A todos os colegas e amigos, que em conversas informais ao longo destes quatro anos, contribuíram com idéias e opiniões, que estarão presentes ao longo de toda a minha vida,

A todos aqueles que de alguma forma contribuíram para a realização deste trabalho. 


\section{SUMÁRIO}

\section{Página}

RESUMO ........................................................... ix

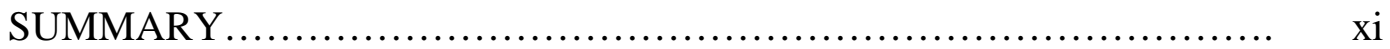

1 INTRODUÇÃO ............................................................... 1

2 REVISÃO DE LITERATURA.................................... 4

2.1 Taxonomia.......................................................... 4

2.2 Origem e evolução das bananeiras cultivadas......................... 5

2.3 Cultivares................................................. 6

2.4 Melhoramento genético...................................... 7

2.5 Marcadores moleculares em Musa.............................. 12

3 DETECÇÃO DO POLIMORFISMO DE MICROSSATÉLITE EM GÉIS DE POLIACRILAMIDA DESNATURANTE POR MEIO DA COLORAÇÃO COM PRATA...................................... 19

Resumo..................................................... 20

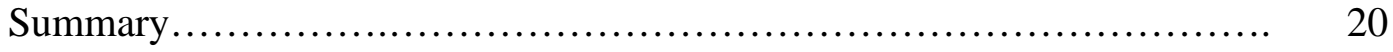

3.1 Introdução.................................................. 21

3.2 Material e Métodos............................................. 23

3.2.1 Extração do DNA e condições da PCR ............................ 23

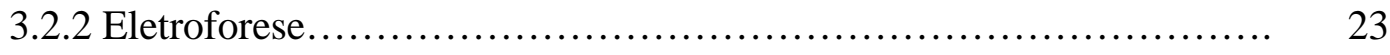

3.2.3 Coloração com prata.......................................... 25

3.3 Resultados e Discussão......................................... 26

3.4 Conclusões.............................................. 30 
4 VARIABILIDADE GENÉTICA EM CULTIVARES DE BANANEIRA $\begin{array}{lll}\text { Musa spp }) \text { REVELADA POR MARCADORES } & \end{array}$ MICROSSATÉLITES............................................ 31

Resumo...................................................... 32

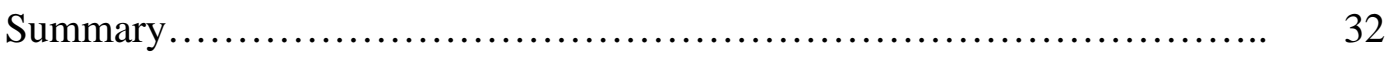

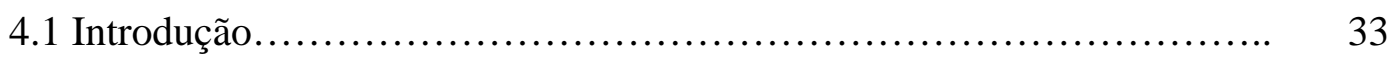

4.2 Material e Métodos............................................ 35

4.2.1 Material.................................................. 35

4.2.1.1 Material vegetal........................................... 35

4.2.1.2 Primers microssatélites................................... 35

4.2.2 Métodos................................................. 35

4.2.2.1 Extração do DNA e condições da PCR............................ 35

4.2.2.2 Condições da eletroforese e detecção do polimorfismo.............. 39

4.2.2.3 Análise dos dados........................................ 39

4.3 Resultados................................................. 39

4.3.1 Polimorfismo de microssatélites entre genótipos de bananeira......... 39

4.3.2 Relações genéticas.......................................... 41

4.3.3 Discriminação de genótipos pertencentes a um mesmo subgrupo...... 42

4.3.4 Discriminação híbridos compartilhando o mesmo parental feminino... 44

4.4 Discussão................................................... 44

4.5 Conclusão.................................................... 48

5 VARIABILIDADE GENÉTICA EM GENÓTIPOS DIPLÓIDES DE Musa acuminata E CULTIVARES TRIPLÓIDES DE BANANEIRA REVELADA POR MARCADORES MICROSSATÉLITES............... 49

Resumo..................................................... 50

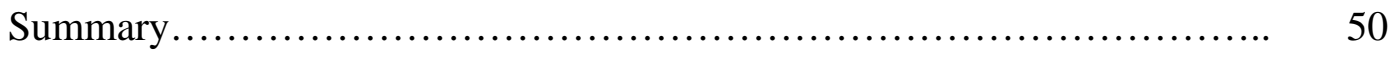

5.1 Introdução.................................................... 51

5.2 Material e Métodos............................................. 53

5.2 .1 Material.................................................... 53

5.2 .1 .1 Material vegetal........................................ 53 
5.2.1.2 Primers microssatélites....................................... 53

5.2.2 Métodos......................................................... 55

5.2.2.1 Extração do DNA e condições da PCR .............................. 55

5.2.2.2 Condições da eletroforese e detecção do polimorfismo................ 57

5.2.2.3 Análise dos dados.............................................. 58

5.3 Resultados...................................................... 59

5.3.1 Similaridade genética e análise em cluster.............................. 61

5.3.2 Similaridade genética entre e dentro dos genótipos diplóides e

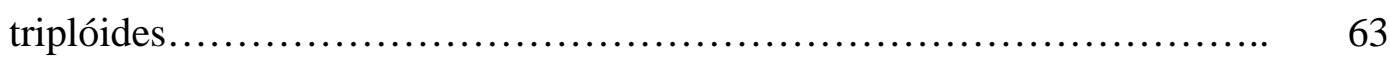

5.3.3 Estrutrura genética avaliada pelo parâmetro $R_{\text {st }} \ldots \ldots \ldots \ldots \ldots \ldots \ldots \ldots . . . \ldots \ldots$

5.4 Discussão........................................................ 65

5.5 Conclusões.......................................................... 69

6 CONCLUSÕES GERAIS........................................ 70

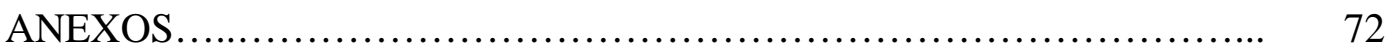

REFERÊNCIAS BIBLIOGRÁFICAS.................................... 76 


\title{
AVALIAÇÃO DA VARIABILIDADE GENÉTICA EM Musa spp. UTILIZANDO MARCADORES MICROSSATÉLITES
}

\author{
Autora: SILVANA APARECIDA CRESTE DIAS DE SOUZA \\ Orientador: Prof. Dr. AUGUSTO TULMANN NETO \\ Co-orientador: Prof. Dr. ANTONIO VARGAS DE OLIVEIRA FIGUEIRA
}

\section{RESUMO}

Em todo o mundo, a cultura da banana tem enfrentado uma série de problemas relacionados a ocorrência de doenças e pragas, para as quais, a obtenção de cultivares resistentes é a forma mais viável de controle. Híbridos tetraplóides promissores, obtidos a partir do cruzamento de cultivares triplóides com diplóides cultivados, selvagens ou melhorados, têm sido produzidos pelos diferentes programas de melhoramento. No entanto, o sucesso num programa de melhoramento depende inicialmente do completo conhecimento da diversidade genética do germoplasma disponível. Os marcadores microssatélites constituem-se em ferramentas valiosas para este fim. Este trabalho objetivou caracterizar, por marcadores microssatélites, 84 genótipos de Musa, a partir do estabelecimento de uma metodologia de detecção do polimorfismo em géis de seqüenciamento, por meio da coloração com prata. Os genótipos foram analisados em dois experimentos distintos. No primeiro experimento, as relações genéticas existentes entre 35 genótipos, compreendendo cultivares triplóides, raças locais (landraces) e híbridos tetraplóides foram investigadas empregando-se 11 primers SSRs. A análise 
fenética obtida mostrou concordância com a caracterização baseada em descritores morfológicos. Os genótipos agruparam-se com base na composição genômica, grupo genômico e subgrupo. Alguns híbridos tetraplóides apresentaram distorções na proporção de alelos doados pelo genitor feminino triplóide, o que suporta constatações recentes sobre a ocorrência de recombinação durante a formação dos gametas femininos. No segundo experimento, nove primers SSRs foram empregados na caracterização de 49 genótipos diplóides, divididos em três 'subgrupos' (cultivados, selvagens e melhorados) e na determinação das relações genéticas existentes entre estes materiais e nove cultivares comerciais triplóides. A análise fenética conduzida sobre todos os genótipos, não evidenciou uma perfeita separação dos genótipos diplóides em seus respectivos subgrupos, possivelmente devido a existência de muitos alelos comuns a eles. A estatística $R_{s t}$ confirmou este resultado. Alguns genótipos diplóides exibiram uma forte relação com as cultivares triplóides AAA tipo exportação. Os marcadores microssatélites mostraram-se altamente eficientes na caracterização e discriminação do germoplasma de Musa, gerando fingerprinting únicos para um grande número de genótipos. Um grande número de alelos pôde ser detectado, o que comprovou a natureza multialélica deste tipo de marcador. Os genótipos diplóides foram os que apresentaram a maior diversidade, refletida pelo maior número de alelos detectados e pela baixa similaridade entre os clones. Nos dois experimentos, observou-se uma alta proporção de alelos "multiplex", bem como locos duplicados, o que resultou na perda do caráter codominante dos marcadores SSRs. As implicações decorrentes destas observações foram consideradas. A metodologia de coloração com prata apresentada mostrou ser um procedimento eficiente, rápido, simples e de baixo custo na detecção do polimorfismo SSRs. 


\title{
EVALUATION OF GENETIC VARIABILITY IN Musa spp. USING MICROSATTELITE MARKERS
}

\author{
Author: SILVANA APARECIDA CRESTE DIAS DE SOUZA \\ Adviser: Prof. Dr. AUGUSTO TULMANN NETO \\ Co-adviser: Prof. Dr. ANTONIO VARGAS DE OLIVEIRA FIGUEIRA
}

\section{SUMMARY}

The banana (Musa) industry has faced various disease and pest problems all over the world, and the development of resistant cultivars is the most attractive way of control. Promising tetraploid hybrids, derived from crosses between triploid cultivars and wild, cultivated or selected diploids, have been developed from different breeding programs. However, the success in a breeding program depends on the knowledge about the genetic diversity of the available germplasm. Microsattelite is an important tool for estimating the genetic diversity. This work aimed to characterize 84 Musa genotypes using microsattelite markers, based on a method for polymorphism detection with electrophoresis on sequencing gel stained with silver nitrate. The genotypes were analyzed in two experiments. In the first one, the genetic relationships between 35 genotypes, including triploid cultivars, landraces and tetraploid hybrids, were investigated using 11 microsattelite primers. The phenetic analysis disclosed a grouping in agreement with the characterization based on morphological descriptors. The genotypes clustered according to genomic composition, genomic group and subgroup. 
Some tetraploid hybrids presented distortion of the proportion of alleles donated by the female triploid genitor, in support to recent description about the occurrence of recombination during female gamete formation. In the second experiment, 9 microsattelite primers were used to characterize 49 diploid genotypes, divided into three subgroups (cultivated, wild and selected) and to determine the genetic relationships between these genotypes and 9 commercial triploid cultivars. The phenetic analysis of all the genotypes did not demonstrate a separation of the diploid genotypes into the respective subgroups, possibly because of the occurrence of various alleles in common The statistic $R_{s t}$ confirmed this result. Some diploid genotypes showed a strong relationship with export-type triploid AAA cultivars. Microsattelite markers were shown to be highly efficient for Musa germplasm characterization and discrimination, generating unique fingerprinting for a large number of genotypes. A large number of alleles was detected, demonstrating the multi-allelic nature of this marker. The diploid genotypes presented the largest diversity, reflected by the largest number of detected alleles and by the low similarity between clones. In both experiments, a large proportion of multiplex alleles was, as well as duplicated loci, resulting in the loss of the codominant character of the marker. The resulting implications were considered. The methods of silver staining showed to be a quick, simple, efficient, and low-cost procedure to detect SSR polymorphism. 


\section{INTRODUÇÃO}

A banana (Musa spp.) é uma das frutas mais consumidas no mundo, sendo explorada na maioria dos países tropicais. A nível mundial, ocupa o quarto lugar em termos de importância alimentar, após o arroz, trigo e leite (Crouch et al., 1999b). A banana é rica em carboidratos (24\%), fibras (6-7\%), como também em elementos minerais e vitaminas, como potássio, magnésio, cálcio fósforo, sódio, ferro e vitaminas A, B e C (Sharrock \& Lusty, 2001).

Cultivada quase que exclusivamente por pequenos agricultores, possui notável papel sócio-econômico em muitos países tropicais em desenvolvimento, sendo de importância tanto como fonte de alimento como fonte de divisas para o mercado local e internacional.

O Brasil é o segundo produtor mundial, com produção aproximada de 7,2 milhões de toneladas, numa área de 480 mil hectares (FNP - consultoria e comércio, 2001). Apesar do volume produzido, as exportações brasileiras atingem apenas $1 \%$ da produção, com destinos aos países do Mercosul, principalmente Uruguai e Argentina. Este baixo índice de exportação está relacionado principalmente à baixa qualidade do produto nacional e ao elevado consumo interno da fruta (FNP - consultoria e comércio, 1998).

Em todo o mundo, a cultura da banana tem enfrentado uma série de problemas relacionados à infestação de patógenos e pragas, para as quais, na ausência de variedades melhoradas, o emprego de pesticidas é a única forma de controle. O elevado custo desta forma de controle está fora do alcance de muitos pequenos agricultores, que são os mais prejudicados com perdas na produção. Para os grandes produtores, o controle químico representa um custo econômico e ambiental considerável (Frison et al., 1997). 
Portanto, há uma grande necessidade de se obter variedades geneticamente melhoradas, garantindo uma produção sustentável e ambientalmente segura.

Porém, a ocorrência de triploidia nas cultivares comerciais dificulta o melhoramento genético desta cultura, o qual envolve hibridações interespecíficas e interplóides (Crouch et al., 1999a).

Híbridos tetraplóides promissores, obtidos a partir do cruzamento de cultivares triplóides (AAA ou AAB) com diplóides (AA) cultivados, selvagens ou melhorados, têm sido produzidos pelos diferentes programas de melhoramento em todo o mundo. No entanto, resta ainda um enorme potencial do aumento da produtividade por meio do melhoramento genético (Crouch et al., 1999b).

Avanços consideráveis têm sido obtidos na compreensão da base genética de características de importância agrícola em banana (Ortiz, 1995). Entretanto, para que maiores avanços sejam alcançados no melhoramento desta cultura, existe uma necessidade urgente de se obter progressos similares na compreensão da estrutura genômica e das relações genéticas existentes entre os acessos depositados nos bancos de germoplasma (Crouch et al., 1999b).

O desenvolvimento e aplicação de tecnologias baseadas em marcadores moleculares, fornecem ferramentas únicas, capazes de revelar polimorfismos ao nível de sequiências de DNA, suficientes para discriminar a variação genética existente entre indivíduos e dentro de populações (Kresovich et al., 1995). Dentre os marcadores existentes, os microssatélites têm sido considerados os ideais para caracterização e avaliação da variabilidade genética em Musa, pois são co-dominantes, multialélicos, reprodutíveis e amplificados via PCR (Grapin et al., 1998). Entretanto, aplicação rotineira dos marcadores microssatélites requer que a relação custo/benefício seja considerada. Apesar do custo e trabalho requeridos no desenvolvimento de sequiências que flanqueiam regiões do DNA contendo os microssatélites, vários primers foram desenvolvidos e disponibilizados para estudos em banana (Lagoda et al., 1998b, Couch et al., 1998). Porém, a detecção do polimorfismo SSRs foi originalmente desenvolvida empregando-se métodos radioativos ou fluorescentes. Tais procedimentos, além de caros, requerem condições especiais de trabalho, as quais não se adaptam a realidade de 
pesquisa de muitos laboratórios de pesquisa. Trabalhos recentes demonstraram a eficiência na detecção de ácidos nucléicos empregando-se a coloração com prata, a qual pôde ser comparada aos métodos radioativos e fluorescentes Comincini et al., 1995; Christense et al., 1999).

Por meio do emprego de marcadores microssatélites, este trabalho teve como principais objetivos:

1. estabelecer uma metodologia de detecção do polimorfismo em géis de seqüenciamento, empregando-se a coloração com prata;

2. caracterizar 35 cultivares de banana, compreendendo cultivares comerciais triplóides e híbridos tetraplóides, de ampla aceitação no mercado nacional;

3. caracterizar 49 genótipos diplóides, compreendendo genótipos cultivados, selvagens e melhorados;

4. verificar as relações genéticas existente entre e dentro dos genótipos diplóides cultivados, selvagens e melhorados;

5. verificar as relações genéticas existentes entre os genótipos diplóides e cultivares comerciais triplóides. 


\section{REVISÃO DE LITERATURA}

\subsection{Taxonomia}

A banana (Musa spp. L.) compreende plantas gigantes, herbáceas perenes, pertencentes a classe Monocotyledonae, família Musaceae, ordem Scitaminae, que se desenvolvem em áreas tropicais e subtropicais úmidas. É propagada vegetativamente por meio de mudas ou brotos, embora as espécies selvagens sejam propagadas por sementes (Simmonds, 1973).

Taxonomicamente, o gênero Musa divide-se em cinco secções: Callimusa, Rhodochlamys, Australimusa, Ingentimusa e Eumusa. As secções Callimusa $(2 \mathrm{n}=2 \mathrm{x}=$ 20) e Rhodohlamys $(2 \mathrm{n}=2 \mathrm{x}=22)$ possuem apenas interesse ornamental. A secção Ingentimusa possui apenas uma espécie, Musa ingens $(2 n=2 \mathrm{x}=14)$. A secção Australimusa $(2 n=2 \mathrm{x}=20)$ contém o grupo de bananas comestíveis conhecidas como Fe'i (Musa maclayi) e a espécie Musa textilis, cultivada para produção de fibras. A secção Eumusa $(2 n=2 \mathrm{x}=22)$ é a mais importante do gênero, pois contém a maioria de cultivares de banana. Esta secção inclui dez espécies: Musa acuminata, Musa balbisiana, Musa basjoo, Musa cheesmani, Musa flaviflora, Musa halabanensis, Musa itinerans, Musa nagensium, Musa schizocarpa e Musa sikkimensis (Novak, 1992). Plantas selvagens de Musa acuminata são classificadas em sete subespécies: Musa acuminata burmanica, M. a. burmanicoides, M. a. banksii, M. a. malaccensis, M. a. siamea, M. a. zebrina e M. a. microcarpa (Jenny et al., 1999). 


\subsection{Origem e evolução das bananeiras cultivadas}

A evolução da maioria das cultivares de banana ocorreu no Continente Asiático,

a partir da hibridação intra ou interespecífica de duas espécies selvagens diplóides, a saber: Musa acuminata e Musa balbisiana, da secção Eumusa (Simmonds \& Shepherd, 1955).

Duas importantes alterações determinaram a domesticação da bananeira. A ocorrência de partenocarpia por mutação em Musa acuminata, seguida da existência de esterilidade feminina resultou no desenvolvimento dos frutos sem a ocorrência de polinização (Kaemmer et al., 1992). Por meio da seleção humana, vários clones passaram a ser cultivados nas áreas úmidas do sudeste Asiático, particularmente na Malásia. Dessa forma, as cultivares primitivas foram diplóides, completamente derivadas de Musa acuminata e denominadas diplóides AA. Cultivares triplóides de Musa acuminata (AAA; $3 x=33$ ) passaram a ocorrer como resultado de hibridizações, nas quais diplóides partenocárpicos, parcialmente estéreis, cruzaram-se com formas macho férteis. Por apresentarem frutos maiores e serem mais produtivos, os clones triplóides foram preferidos em relação aos diplóides, substituindo-os em muitos locais (Sharrock, 1998).

Nas áreas secas da Ásia, onde predominam formas selvagens de Musa balbisiana, ocorreu um desenvolvimento evolucionário paralelo, conduzindo ao aparecimento de cultivares diplóides e triplóides puramente balbisiana, reconhecidos primeiramente nas Filipinas (Valmayor et al., 1991). A sobreposição da distribuição natural de Musa acuminata e Musa balbisiana nesta região, associada a existência de autocompatibilidade entre estas duas espécies, levou ao aparecimento das bananeiras de constituição genômica $\mathrm{AB}, \mathrm{AAB}$ e $\mathrm{ABB}$. Os tetraplóides dos grupos $\mathrm{AAAA}, \mathrm{AAAB}$, AABB,ABBB evoluíram de forma similar. A participação de duas espécies da secção Australimusa, Musa schizocarpa (genoma S) e Musa angustigemma (genoma T) em algumas cultivares de Nova Guiné foi recentemente comprovada por hibridação in situ, sendo possível a ocorrência de combinações AS, AAS e ABBS, AAT, ABBT, nesta região (D’Hont et al., 2000). 
Embora o sudeste da Ásia seja considerado o centro de origem das espécies de Musa (Simmonds, 1995), uma grande diversidade de banana existe na África sub-Saara, onde diferentes tipos são cultivados em diferentes sub-regiões. Dessa forma, os plátanos (grupo de cultivares de constituição genômica $\mathrm{AAB}$, impalatáveis quando cruas) são predominantes nas áreas de planícies ao oeste e ao centro da África, enquanto que bananas AAA prevalecem em áreas montanhosas no leste Africano (Vuylsteke, 2001). Por este motivo, a África é considerada um centro secundário de diversidade de bananas e plátanos, a qual é resultante de mutações somáticas e seleção humana durante o longo período de cultivo nesta região (De Langhe, 1969). A introdução da banana nos demais continentes ocorreu com a expansão do comércio, atingindo toda a costa asiática banhada pelo oceano Índico, e posteriormente, difundindo-se pela costa africana, atingindo as Américas com as conquistas européias (De Langhe, 1995).

\subsection{Cultivares}

Apesar de haver um grande número de cultivares de banana, Cheesman, (1948) as classificou em três grupos morfologicamente distintos. O primeiro grupo apresenta predominância dos caracteres botânicos de Musa acuminata; o segundo, exibe as características principais de Musa balbisiana e o terceiro, combina as características destas duas espécies, sendo portanto, híbridos interespecíficos naturais. As variações morfológicas observadas por Cheesman (1948) refletem principalmente alterações na

coloração do pseudocaule, presença de manchas na base do pecíolo, sua coloração, a forma do canal peciolar, variações da inflorescência, tamanho e formato dos frutos e coloração da polpa.

Simmonds \& Shepherd (1955), propuseram um sistema de classificação das cultivares de banana atualmente aceito no mundo todo, o qual baseia-se num esquema de notas sobre quinze descritores morfológicos, permitindo agrupar as cultivares a seus respectivos grupos genômicos. Assim, cada cultivar é avaliada para cada um dos quinze descritores, sendo que para cada caracter com aderência perfeita à Musa acuminata é atribuído o valor 1 e para cada caracter com aderência perfeita à Musa balbisiana, atribui-se valor 5. Segundo esse esquema, Musa acuminata possui valor 15 (15 x 1) e 
Musa balbisiana, valor 75 (15 x 5). Expressões intermediárias dos caracteres são registradas, assumindo-se valor 2, 3 e 4 . As cultivares híbridas devem ter um total de pontos entre 15 e 75 . Porém, na prática, ligeiros desvios em torno desses valores são permitidos, de forma que as cultivares puramente acuminata devem possuir valores entre 15 e 25 pontos e cultivares puramente balbisiana, entre 70 e 75 . Os híbridos são esperados entre 26 e 69 pontos, tendo-se: AA/AAA: 15 - 25 pontos; AAB: 26 - 46; AB/AABB: 47 - 49; ABB: 59 - 63; ABBB: 67 - 69; BB/BBB:70 - 75 pontos.

Além da definição de grupos genômicos, foi estabelecido o uso do termo 'subgrupo', para denominar um conjunto de cultivares provenientes de mutações de uma única cultivar original (Simmonds, 1973).

As produção de banana visando o mercado de exportação está concentrada em cultivares do subgrupo 'Cavendish' de constituição genômica AAA, enquanto um grande número de cultivares de constituição $\mathrm{AAA}, \mathrm{AAB}$ e $\mathrm{ABB}$ são cultivadas para consumo local em diversas regiões no mundo. De acordo com Silva et al. (1997), no Brasil predominam cultivares locais ou 'landraces' de constituição genômica AAB como 'Prata' 'Pacovan' e 'Maçã', que juntas correspondem a 75\% da área plantada, seguindose pelas cultivares do subgrupo 'Cavendish' (AAA) como 'Nanica' e 'Nanicão' (21\%).

\subsection{Melhoramento genético}

Em todo o mundo, a cultura da banana tem enfrentado uma série de problemas causados principalmente pela infestação de patógenos e pragas, os quais são responsáveis por grandes perdas na produção. Dentre estes, os fungos correspondem aos agentes infecciosos de maior importância, pois determinam o aparecimento da murcha de Fusarium ou mal-do-Panamá, como também manchas foliares, representadas principalmente pela Sigatoka amarela e Sigatoka negra, esta última recentemente introduzida da região norte do Brasil (Silva et al., 1999). Entre as bacterioses, destaca-se o Moko ou murcha bacteriana, a qual constitui-se numa constante ameaça para os produtores brasileiros, visto que todas as cultivares são altamente susceptíveis. O nematóide de maior importância é o Radopholus similis, enquanto que a broca-do- 
rizoma constitui-se na principal praga para a cultura.

O melhoramento genético da bananeira iniciou-se em 1922 em Trinidad e em 1924 na Jamaica, quando a murcha do Fusarium dizimou as plantações de 'Gros Michel' na América Central e na Jamaica. O objetivo desses dois programas era produzir um híbrido de 'Gros Michel' resistente ao fusarium. Posteriormente, passou-se a objetivar também resistência à Sigatoka. No início da década de 30, foi obtido o primeiro híbrido tetraplóide resistente ao Fusarium e à Sigatoka, a partir do cruzamento da cultivar triplóide 'Gros Michel' e a espécie selvagem diplóide Musa acuminata malaccensis. Apesar do híbrido obtido não apresentar performance comercial, havia sido delineado um sistema de hibridação que permitia o melhoramento genético da banana (Silva et al., 1999). Desde então, programas de melhoramento foram iniciados em vários países, objetivando a produção de cultivares com resistência a pragas e doenças e melhoria na qualidade dos frutos. Assim, híbridos de banana têm sido desenvolvidos em Honduras pela FHIA (Fundación Hondureña de Investigación Agrícola), na Nigéria pelo IITA (International Institute of Tropical Agriculture), no Brasil pelo CNPMF/Embrapa (Centro Nacional de Pesquisa em Mandioca e Fruticultura), na Índia pela Tamil Nadu Agricultural University, e em Guadalupe pelo CIRAD (Centre de Coopération Internacionale en Recherche Agronomique pour le Développment). A nível internacional, o INIBAP (International Network for the Improvement of Banana and Plantain) tem a função de coordenar os diferentes programas de melhoramento e também, promover o intercâmbio de germoplasma.

Os primeiros híbridos melhorados foram produzidos pela FHIA e estão sendo testados em mais de 50 países; alguns deles, cultivados atualmente em escala comercial por agricultores. Híbridos de plátanos resistentes à Sigatoka negra foram produzidos pelo IITA e estão sendo avaliados na África. No Brasil, híbridos resistentes à Sigatoka (amarela e negra) e ao mal-do-panamá, desenvolvidos pela Embrapa, estão sendo avaliados em diversos locais e fornecidos a agricultores brasileiros (Frison et al., 1997; Vuylsteke, 2001; Silva et al., 1998, 1999)

Apesar dos resultados obtidos, o melhoramento genético da banana é difícil e trabalhoso, tendo sido considerado por muito tempo como impraticável. A propagação 
vegetativa, a baixa fertilidade dos clones, a ocorrência de triploidia e o tempo requerido para se produzir uma cultivar melhorada impedem o rápido progresso no melhoramento. Porém, a incorporação de resistência é o meio mais eficiente no controle de doenças, sendo que a descoberta de fontes de resistência e a avaliação da fertilidade feminina devem se constituir nas prioridades de um programa de melhoramento (Vuylsteke, 2001).

$\mathrm{Na}$ bananeira, a variabilidade genética importante localiza-se entre as diversas formas selvagens da espécie Musa acuminata e nas cultivares do grupo AA, as quais são usadas como genitores masculinos no melhoramento e deverão contribuir com resistência a doenças como mal-do-Panamá, Sigatoka amarela, Sigatoka negra e Moko e ainda com outras características agronômicas favoráveis (Silva et al., 1999). Musa balbisiana, apresenta genes resistência a diversos patógenos e pragas, genes de tolerância a seca, porém, é pouco variável para os caracteres agronômicos como tamanho e formato dos frutos (Dantas et al., 1993, Jenny et al., 1999).

Apesar do sucesso na utilização direta dos diplóides selvagens na produção de híbridos resistentes a Sigatoka negra, o desenvolvimento de diplóides melhorados também é considerado um importante componente no melhoramento genético (Vuylsteke, 2001). Sendo assim, o melhoramento convencional inicia-se com a hibridação e seleção de recombinantes a nível diplóide, cujo objetivo é concentrar, em um mesmo genótipo , um maior número de caracteres desejáveis.

De acordo com Dantas et al. (1993) na produção de cultivares melhoradas são consideradas quatro classes de hibridação:

a) triplóides resultantes de cruzamentos de diplóides com diplóides, com a recombinação apenas no genitor diplóide masculino. Apesar das cultivares existente supostamente terem evoluído desta forma, muito poucos resultados foram obtidos na produção de cultivares melhoradas, empregando-se esta metodologia.

b) tetraplóides resultantes de cruzamentos entre tetraplóides com segregação nos dois parentais. As bananeiras tetraplóides, sejam espontâneas ou sintetizadas, possuem número de cromossomos múltiplo de 11 e, 
teoricamente, deveriam ser mais férteis que os triplóides. O pólen diplóide dos tetraplóides, entretanto, apresenta uma viabilidade bem reduzida, que raramente permite a autofertilização ou a fertilização de outros tetraplóides. Em função disso, a produção de tetraplóides secundários é dificilmente praticável, devido à baixíssima produção de sementes,

c) triplóides resultantes de cruzamentos entre tetraplóides e diplóides, também com segregação nos dois parentais. Utilizando-se o pólen A de diplóides, é freqüentemente possível obter bons rendimentos de sementes e, conseqüentemente, híbridos secundários triplóides. Entretanto, uma grande variabilidade é liberada, havendo a necessidade de um grande número de plantas para que seja realizada uma seleção eficiente,

d) tetraplóides resultantes do cruzamento entre triplóides e diplóides, com recombinação apenas do parental masculino diplóide. Esta tem sido a metodologia básica aplicada em todos os programas de melhoramento. Diplóides melhorados, macho-férteis, apresentando resistência a doenças e outros caracteres agronômicos são cruzados com cultivares triplóides portadoras de esterilidade parcial. Os híbridos obtidos destes cruzamentos podem ser diplóides, triplóides, tetraplóides e heptaplóides (com 22, 33, 44 e 77 cromossomos respectivamente). Visto que teoricamente a recombinação gamética ocorre apenas do lado do genitor diplóide, apenas os híbridos tetraplóides possuem potencial para serem usados como cultivares comerciais, uma vez que a totalidade do genoma triplóide está representado no híbrido. Este esquema de hibridação retrata portanto, um mecanismo de implantação de características adicionais nas cultivares estabelecidas (Silva et al., 1998), e tem tido aplicação no melhoramento de bananas de mesa AAA e AAB, plátanos $\mathrm{AAB}$ e nas bananas de cozimento $\mathrm{ABB}$. No entanto, a fertilidade de tais cruzamentos é muito baixa e dependente do genótipo. A maioria dos clones $\mathrm{AAA}$ e $\mathrm{AAB}$ produzem menos que 0,1 semente por fruto após polinização com pólen haplóide, enquanto que alguns clones $A B B$ produzem mais de dez sementes por fruto. 
No melhoramento de bananas tipo exportação (AAA), apenas a cultivar 'Gros Michel' e seu variante de porte baixo 'Highgate' são usados como genitores femininos, uma vez que apresentam esterilidade parcial. Clones pertencentes ao grupo 'Cavendish' apresentam resistência ao Fusarium, porém possuem esterilidade feminina completa (Novak, 1992), havendo a necessidade de se usar a indução de mutação ou transformação genética para se ampliar sua base genética. Similarmente, a cultivar 'Maçã', muito apreciada pelo mercado brasileiro, também apresenta esterilidade feminina completa. A obtenção de híbridos tetraplóides tipo 'Maçã' baseia-se na cultivar triplóide 'Yamgambi Km 2', a qual produz frutos com sabor muito semelhante aos da cultivar 'Maçã', com a vantagem de produzir sementes (Silva et al., 1999).

Segundo Dantas et al (1993) triplóides secundários podem ser produzidos a partir da duplicação cromossômica de genótipos diplóides promissores, por meio do tratamento com colchicina e, posteriormente, efetuar cruzamentos tetraplóide x diplóide.

Na última década, o crescente reconhecimento sobre a importância da banana pela comunidade científica, coincidiu os grandes avanços nas técnicas de melhoramento, possibilitando superar, em grande parte, as barreiras existentes no melhoramento desta cultura (Frison et al., 1997). A obtenção de populações segregantes em cruzamento teste, a partir do cruzamento de um triplóide (genitor heterozigoto) e um diplóide (genitor homozigoto recessivo), tornou possível o estudo da herança dos caracteres em Musa (Ortiz, 1995). Assim, atualmente se conhece a herança da resistência a Sigatoka negra (Ortiz e Vuylsteke, 1994a), ao nanismo (Ortiz \& Vuylsteke, 1995b), ao albinismo (Ortiz \& Vuysteke, 1994b), partenocarpia (Ortiz \& Vuylsteke, 1995a), orientação do cacho (Ortiz, 1995), esterilidade feminina e masculina (Ortiz, 1995), peso do cacho e outras características quantitativas (Vuylsteke, 2001). 


\subsection{Marcadores moleculares em Musa:}

A utilização efetiva dos recursos genéticos disponíveis ao melhoramento genético requer um pleno conhecimento da diversidade genética existente. Em um banco de germoplasma, informações precisas sobre alguns parâmetros são imprescindíveis, tais como: a) identidade: a certeza de que um acesso está catalogado corretamente e corresponde ao tipo verdadeiro; b) parentesco: o grau de relação entre os genótipos de um acesso ou entre acessos de uma coleção; c) estrutura: a quantidade de variação genética presente e como ela está fracionada entre indivíduos, acessos e coleções; d) localização: a presença de um gene desejado ou complexo gênico em um acesso específico bem como a existência de uma seqüência de DNA mapeada em um cromossomo particular de um indivíduo (Kresovich et al., 1995). O conhecimento das relações genéticas entre indivíduos aumenta a acurácia na predição da performance híbrida (Panter \& Allen, 1995).

Vários métodos têm sido empregados para investigar a variabilidade genética presente no germoplasma de Musa. Os descritores morfotaxonômicos foram os primeiros a serem desenvolvidos e aperfeiçoados para as bananeiras, e recentemente, 119 descritores foram definidos como norma de descrição do germoplasma de Musa (Ipgri, 1999). Entretanto, muitas características vegetativas são influenciadas por fatores ambientais, apresentam variação contínua e alto grau de plasticidade, podendo muitas vezes, não refletir a real diversidade existente (Lima et al., 2001). Ademais, em Musa, alguns caracteres são expressos somente na fase adulta, podendo ser avaliados somente após longo tempo de plantio no campo (Pillay et al., 2000). Análises fenéticas baseadas em caracteres morfológicos e citológicos conduzidos por Simmonds \& Weatherup (1990) revelaram alta heterogeneidade dentro da secção Eumusa, refletida pelo baixo nível de consistência entre os caracteres. Tal fato levou os autores a dividir a secção Eumusa em duas subsecções informais: 'Eumusa 1' e 'Eumusa 2'.

Marcadores bioquímicos (isoenzimas) foram testados para identificação e classificação de germoplasma de Musa, porém o número de sistemas e o grau de

polimorfismo obtido limitaram sua utilidade na identificação de clones e estimativa da 
diversidade genética (Gawel \& Jarret, 1991, Carvalho et al., 1998).

O advento de técnicas possibilitando detectar polimorfismos a nível de DNA tem gerado um grande número de marcadores moleculares para análises genéticas e fingerprinting dos indivíduos (Jeffreys et al., 1985).

Gawel et al. (1992) caracterizaram por marcadores RFLP (restriction fragment length polymorphisms) 19 espécies do gênero Musa pertencentes às secções Eumusa, Callimusa, Rhodochlamys e Australimusa, empregando 66 sondas de DNA genômico. Diferentemente dos marcadores morfológicos, a análise fenética obtida não evidenciou uma clara distinção entre as espécies da secções Eumusa e Rhodochlamys.

Jarret et al. (1992) caracterizaram por RFLP 26 acessos diplóides pertencentes a diferentes secções do gênero, incluindo formas partenocárpicas e selvagens. Alto polimorfismo foi observado entre os acessos selvagens de Musa acuminata. As cultivares nativas de Papua Nova Guiné não apresentaram relação à Musa balbisiana e a Musa Schizocarpa, porém, apresentaram alta homologia à Musa acuminata. Relações filogenéticas entre espécies de Musa foram também investigadas por RFLP empregando-se sondas do DNA do cloroplasto (Gawel \& Jarret, 1991).

Fauré et al. (1994) avaliaram por RFLP o mecanismo de transmissão do DNA citoplasmático em bananeiras diplóides. Progênies obtidas a partir de cruzamentos controlados foram analisadas empregando-se sondas de DNA cloroplástico e mitocondrial. Os resultados revelaram a herança materna do DNA cloroplástico e paterna do DNA mitocondrial, sugerindo a existência de dois mecanismos separados de transmissão de organelas. O conhecimento sobre o modo de herança das organelas constitui-se num importante fator a ser considerado em estudos de filogenia no gênero e oferece uma nova ferramenta para confirmar a origem híbrida de um material.

A produção de progênies híbridas de cruzamentos entre triplóides comerciais e diplóides (homozigotos recessivos para os caracteres) ou ainda entre diplóides tem possibilitado o estudo de herança dos caracteres em Musa. Um mapa genômico de ligação foi estabelecido utilizando marcadores moleculares do tipo RFLP, para cruzamentos entre uma cultivar diplóide e $M$. acuminata ssp banksii, sem relação, portanto com as bananas de mesa comerciais (Fauré et al., 1993). 
Kaemmer et al., (1992) utilizaram seqüências de minissatélites e amplificação aleatória (RAPD) na avaliação do polimorfismo de quinze espécies e cultivares representativas do gênero $M u s a$, compreendendo genótipos AA, AAA, AAAA, AAB, $\mathrm{ABB}$ e $\mathrm{BB}$, tendo sido possível identificar bandas específicas de genoma A e B. A identificação de marcadores de genoma A e B é de grande interesse para o melhoramento, pois permite que a definição da composição genômica de um híbrido seja feita ainda em estágio de plântula ou in vitro, contornando os problemas que envolvem a lenta propagação da planta, o longo ciclo da cultura (18-24 meses) e o grande espaço requerido. Pillay et al. (2000) identificaram marcadores RAPD específicos de genoma A e B, o que permitiu aos autores redefinir a composição genômica de alguns clones, previamente classificados pelos descritores morfológicos. Howell et al. (1994) identificaram marcadores RAPD específicos a nove genótipos de Musa, representados pelos genomas $\mathrm{AA}, \mathrm{AAA}, \mathrm{AAB}, \mathrm{ABB}$ e $\mathrm{BB}$. Recentemente, técnicas de citometria de fluxo e hibridação in situ também têm sido empregadas em complementação aos marcadores moleculares, na determinação da composição genômica dos clones de banana (Osuji et al., 1997; Lysak et al., 1998; D’Hont et al., 2000; Kamaté et al., 2001).

O potencial do uso de marcadores RAPDs para identificação precoce de variantes somaclonais aliado à caracterização desses clones, tem sido avaliado em Musa. Kaemmer et al., (1992), identificaram em bananeira um polimorfismo de RAPD entre um mutante induzido ('GN 60') de 'Grande Naine' e a planta original. Mais recentemente, Damasco et al., (1996) avaliaram 57 plantas normais e 59 plantas anãs de bananeira Cavendish utilizando 66 primers arbitários, e identificaram um primer (OPJ 04) capaz de amplificar um fragmento de 1500 pares de base, presente apenas nas plantas normais. Ford-Lloyd et al. (1992) avaliaram a instabilidade genética em germoplasma de Musa mantido in vitro, empregando-se marcadores RAPD.

Bhat \& Jarret (1995) demonstraram a utilidade dos marcadores RAPD na caracterização do germoplasma de Musa, tendo sido possível diferenciar clones que se mostravam idênticos sob o ponto de vista morfológico. Mais recentemente, Loh et al. (2000) detectaram fingerprinting únicos para 12 das 16 cultivares avaliadas, empregando-se apenas oito combinações de primers AFLP. 
Considerando que existem algumas regiões do genoma que apresentam mais polimorfismos do que seqüências de cópia única, marcadores moleculares específicos para essas regiões foram desenvolvidos. Um marcador potencial é qualquer sequiência de DNA capaz de detectar polimorfismo, e em geral, quanto mais polimórfico, mais informações ele contém, tornando mais fácil detectar diferenças entre indivíduos. DNA não codificante é, sobre este ponto de vista, mais interessante que DNA codificante, pois acumula mais mutações e não está sujeito à pressão seletiva. DNA não codificante é representado principalmente por DNA repetitivo, denominado microssatélite, minissatélites ou DNA satélite, dependendo do comprimento da seqüência (Testolin et al., 2000). Microssatélites, também conhecidos como Simple Sequence Repeats (SSRs), possuem seqüências curtas, com 2 a 5 pares de base, enquanto que os minissatélites, seqüências mais longas, com aproximadamente 20 pares de base (Dowling et al., 1996). Freqüentemente, estes dois tipos de marcadores são referidos como VNTRs (Variable Number of Tandem Repeats). Estes marcadores além de serem altamente polimórficos e heterozigotos, possuem outras características comumente requeridas em marcadores, tais como: padrão de herança mendeliana, codominância, estabilidade somática, confiabilidade e reprodutibilidade do método de análise (Testolin et al., 2000). Minissatélites localizam-se próximo aos telômeros, e as variações em seu comprimento são devidas a recombinações intramoleculares/interalélicas e conversão gênica (Jeffreys et al., 1991). Minissatélites são menos freqüentes e por isso, há poucos relatos de seu uso em plantas (Morgante et al., 1997). Locos minissatélites são tipicamente analisados em perfis multilocos, empregando-se métodos de hibridização (Dowling et al., 1996). Inversamente, os microssatélites são muito freqüentes e distribuídos aleatoriamente por todo o genoma, facilmente encontrados em bancos de dados de DNA (Morgante \& Olivieri, 1993) ou através de isolamento de clones positivos de uma biblioteca genômica após hibridação com sonda específica (Thomas e Scott, 1993). A maioria dos microssatélites são baseados em repetições de dinucleotídeos $\left[(\mathrm{AC})_{\mathrm{n}},(\mathrm{AG})_{\mathrm{n}} \mathrm{e}(\mathrm{AT})_{\mathrm{n}}\right]$, as quais podem ser amplificadas via PCR usando primers complementares às regiões que flanqueiam estas repetições, o que resulta num polimorfismo devido a diferenças nos comprimentos dos fragmentos após a eletroforese (Staub et al., 1996). Estas diferenças 
derivam de variações no número de repetições, e são provenientes de escorregamento ('slippage') da DNA polimerase durante a replicação do DNA ou de crossing-over' desigual entre cromátides irmãs (Valdes et al., 1993). Fragmentos microssatélites são melhor resolvidos em géis de poliacrilamida desnaturante, sendo possível detectar diferenças de apenas dois pares de base (Litt et al., 1993). A visualização do polimorfismo pode ser realizada pela coloração direta (coloração com nitrato de prata) ou indireta (marcação radioativa ou flurescente dos nucleotídeos).

Os SSRs têm sido identificados em um grande número de espécies vegetais, e são os marcadores ideais para construção de mapas genéticos de alta resolução e identificação de locos controladores de características de interesse (Devey et al., 1996), estudos genéticos de conservação e de populações (Powell et al., 1995, Rajora et al., 2000), identificação clonal (Sanchez-Escribano et al., 1999); monitoramento e certificação de cruzamentos controlados, identificação de espécies e híbridos e determinação da paternidade (Van de Den \& McNicol, 1996) e seleção assistida por marcadores (Weising et al., 1998; Crouch et al., 1998).

Em Musa, os microssatélites têm sido considerados ideais para deteç̧ão da variabilidade genética inter e intra-específica (Grapin et al., 1998) e na seleção assistida por marcadores. Grapin et al. (1998) utilizaram nove marcadores microssatélites para caracterizar 59 genótipos diplóides de Musa, compreendendo acessos cultivados e selvagens. Os marcadores empregados permitiram aos autores definir as relações genéticas existente entre os acessos, como também discriminar acessos com classificação duvidosa. De Langhe \& Devreux (1960) classificaram o clone 'Calcutta 4' como uma nova subespécie, Musa acuminata burmaniccoides, e portanto, diferente de Musa acuminata burmanica. Estudos conduzidos por RFLP revelaram não haver diferenças entre 'Calcutta 4' e M. a. burmanica. Porém, os marcadores SSR empregados por Grapin et al. (1998) discriminaram estes dois acessos, confirmando a classificação anteriormente proposta por De Langhe \& Devreux (1960). Segundo os mesmos autores, a descrição morfológica de $M$. acuminata errans é muito similar à descrição de $M$. acuminata banksii. Análises RFLP revelaram que o clone 'Agutay' (M. a. errans) era muito similar aos representantes de M. acuminata banksii. O polimorfismo SSR obtido 
por Grapin et al. (1998) discriminou 'Agutai' de M.a. banksii.

Crouch et al. (1998) utilizaram a seleção assistida por marcadores SSRs em híbridos diplóides e tetraplóides provenientes do cruzamento entre a espécie selvagem diplóide M. acuminata ssp. burmanica ('Calcutta 4') e o cultivar triplóide 'Obino l'Ewai'. Um total de 31 pares de primers foram utilizados, dos quais 12 detectaram polimorfismo entre os parentais diplóide e triplóide. Na análise dos híbridos, foi possível detectar um, dois ou três alelos maternos polimórficos, indicando a ocorrência de recombinação durante a formação de gametas $2 n(=3 \mathrm{x})$ no cultivar triplóide. Crouch et al. (1999a) compararam a eficiência dos marcadores RAPD, AFLP e SSRs na detecção da variabilidade genética na progênie tetraplóide proveniente do referido cruzamento. Todos os três métodos detectaram alto polimorfismo entre os genótipos parentais e a progênie tetraplóide, entretanto, os microssatélites foram os marcadores mais polimórficos. Conforme anteriormente observado com os marcadores SSRs, os marcadores AFLP também detectaram alta taxa de recombinação dos alelos do parental feminino na progênie tetraplóide. No entanto, houve baixa correlação das estimativas da diversidade genética entre os genótipos com os diferentes marcadores ensaiados. Segundo estes mesmos autores, para se obter uma boa acurácia das estimativas da diversidade genética existente num germoplasma, é necessário que diferentes marcadores sejam empregados de forma complementar, visto que abrangem regiões diferentes do genoma.

A avaliação de progênies diplóides e tetraplóides provenientes do cruzamento entre triplóides e diplóides é o único meio de se planejar as melhores opções de cruzamento em banana. Assim, por meio do emprego de marcadores microssatélites, Crouch et al. (1999b) identificaram, em progênies segregantes, híbridos diplóides e tetraplóides com potencial para serem empregados como parentais masculinos e femininos, no esquema de melhoramento objetivando a produção de triplóides secundários.

Recentemente, dois mapas genéticos de ligação baseados em marcadores RFLP, RAPD e isoenzimas foram saturados com marcadores microssatélites. A comparação dos diferentes marcadores evidenciou uma grande colinearidade entre os marcadores 
RFLP e SSRs, ambos mostraram-se muito informativos. Os SSRs foram superiores na detecção do polimorfismo (Kaemmer et al., 1997).

O grande poder de discriminação destes marcadores justifica o seu uso quando se pretende obter uma boa representação da diversidade genética existente em Musa, conduzindo a estudos de diversidade inter e intraespecífica e promovendo melhor compreensão do seu genoma (Grapin et al., 1998). 


\section{DETECÇÃO DO POLIMORFISMO DE MICROSSATÉLITES EM GÉIS DE POLIACRILAMIDA DESNATURANTE POR MEIO DE COLORAÇÃO COM PRATA}

\section{S. CRESTE ${ }^{1}$; A. TULMANN-NETO ${ }^{2}$; A. FIGUEIRA ${ }^{2}$.}

1. Departamento de Genética - ESALQ/USP - Av. Pádua Dias, 11 CP 83, Piracicaba SP, 13400-970. Brasil.

2. Centro de Energia Nuclear na Agricultura - CENA/USP - Av. Centenário, 303, CP96, Piracicaba - SP. 13400-970, Brasil.

Palavras-chave: AFLP, Banana, microssatélite, Musa acuminata, PAGE, coloração com prata, SSR.

*Trabalho publicado pela revista Plant Molecular Biology Reporter 


\section{Resumo}

O uso de marcadores moleculares em larga escala no melhoramento de plantas é limitado pelo alto investimento e capacidade de genotipagem. Polimorfismos de DNA podem ser detectados em géis de poliacrilamida desnaturante de forma indireta pela marcação radioativa dos nucleotídeos, ou diretamente, através da coloração. A marcação fluorescente ou radiativa requer infraestrutura sofisticada, nem sempre disponível nos países em desenvolvimento. Neste trabalho, um método melhorado de coloração com prata de baixo custo é apresentado e comparado a dois outros métodos, pela sua habilidade em detectar polimorfismo microssatélite em géis de poliacrilamida aderidos à placas de vidro. Os três procedimentos diferiram basicamente no requerimento de um pré-tratamento de oxidação, pré-exposição com formaldeído durante a coloração com nitrato de prata, inclusão de tiosulfato de sódio e a substituição de carbonato de sódio por hidróxido de sódio para estabelecer condições alcalinas para redução de íons prata. Todos os métodos detectaram o mesmo padrão de bandas e alelos. Entretanto, diferenças significativas na sensibilidade, contraste e background foram observadas. Dois métodos apresentaram sensibilidade superior, detectando até $1 \mu \mathrm{L}$ da reação de amplificação. $\mathrm{O}$ método melhorado apresentou menor background e permitiu a reutilização das reações de coloração. O emprego de géis de seqüenciamento desnaturante de fina espessura $(<1$ $\mathrm{mm}$ ) permite genotipar 60 a 96 amostras em apenas quatro horas. O emprego de pequenos volumes de reação e reutilização das soluções de coloração reduziu os custos de genotipagem.

\section{Summary}

The large-scale use of molecular markers in plant breeding is limited by genotyping throughput capacity for genotyping. DNA polimorphysms can be detected in denaturing polyacrylamide indirectly by nucleotide labeling or directly by staining. Fluorescentlabeling or radiolabeling requires sophisticated infrastructure not always available in developing countries. We present an improved low-coast method for silver staining and compare it to 2 other methods for their ability to detect simple sequence repeat polymorphisms in denaturing polyacrylamide gels bound to glass plates. The 3 
procedures differed in their requirement for an oxidation pretreatment; preexposure with formaldehyde during silver nitrate impregnation, inclusion of sodium thiosulfate, and by their replacement of sodium carbonate for sodium hydroxide to establish alkaline conditions for silver ion reduction. All methods detected the same banding pattern and alleles. However, important differences in sensitivity, contrast and background were observed. Two methods gave superior sensitivity, detecting down to $1 \mu \mathrm{L}$ of loaded amplification products. Our improved method gave lower backgrounds and allowed the reutilization of staining solutions. The use of thin $(<1 \mathrm{~mm})$ denaturing sequencing gels allows genotyping of 60-96 samples within 4 hours. Use of smaller loading samples volumes and reutilization of staining solutions further reduced costs.

\subsection{Introdução}

Marcadores moleculares, tais como simple sequence repeats (SSRs), ou sequence-tagged microsatellite sites (STMS), têm sido amplamente empregados no melhoramento de plantas (i.e. mapeamento genômico, seleção assistida por marcadores) e em estudos de evolução e de conservação. Entretanto, sua aplicação rotineira requer metodologias eficientes para genotipagem em massa (Mitchell et al., 1997). O método mais eficiente para visualização de DNA fita simples em géis de poliacrilamida, emprega a marcação radioativa ou fluorescente dos nucleotídeos. Estes procedimentos requerem condições especiais, são caros e demorados, muitas vezes impraticáveis na maioria dos países tropicais, os quais carecem de infraestrutura sofisticada (Lagoda et al., 1998a).

A coloração com prata foi originalmente descrita para detecção ultrasensível de polipeptídeos separados em eletroforese em gel de poliacrilamida (Merril et al., 1981) e posteriormente adaptada para detecção de ácidos nucléicos (Sommerville e Wang, 1981; Herring et al., 1982; Blum et al., 1987). Beidler et al. (1982) desenvolveram um método fotoquímico de coloração com prata para detecção de ácidos nucléicos com alta sensibilidade (5-7,5 pg DNA $\mathrm{mm}^{-2}$ ). Desde então, pequenas adaptações destes métodos originais de coloração têm sido propostos, visando aumentar a sensibilidade, reduzir o 
número de passos dos procedimentos, eliminar componentes tóxicos e também permitir uma melhor visualização dos fragmentos (Bassam et al., 1991; Santos et al.,1993; Sanguinetti et al., 1994). Bassam et al. (1991) aumentaram a sensibilidade (cerca de 1 pg

$\mathrm{mm}^{-2}$ ) pela inclusão de uma pré-exposição com formaldeído durante a impregnação com nitrato de prata e pela redução na concentração de nitrato de prata, enquanto que background foi reduzido pela inclusão de tiosulfato de sódio e eliminação do tratamento de oxidação com dicromato de potássio e ácido nítrico. Sanguinetti et al. (1994) descreveram pequenas modificações no protocolo, como a substituição do carbonato de sódio por hidróxido de sódio, para estabelecer condições alcalinas na redução dos íons prata à prata metálica por formaldeído, com o qual obteve sensibilidade de $3 \mathrm{pg} \mathrm{mm}^{-2}$. A detecção de ácidos nucléicos empregando-se coloração com prata tem demonstrado ser altamente sensível, com resultados similares a detecção por marcação radioativa ou fluorescente (Comincini et al., 1995; Christensen et al., 1999).

Em geral, estes métodos de coloração com prata foram otimizados para géis desnaturantes com ambas as superfícies livres, não colados à placas de vidro ou plástico. O uso de filme poliéster afeta a qualidade da coloração, pois requer longo tempo de revelação, aumentando o background (Bassam et al., 1991). Para uma otimização na análise, um grande número de amostras pode ser analisado em um único gel de seqüenciamento, mas as manipulações durante a coloração requerem o gel ligado à uma superfície de vidro.

O objetivo deste trabalho foi avaliar um método de coloração com prata de baixo custo, adaptado de Beidler et al. (1982) empregando-se banana (Musa spp.) como um sistema modelo. A sensibilidade deste método foi comparada a dois outros métodos freqüentemente empregados (Bassam et al., 1991; Sanguinetti et al., 1994). As condições para detecção dos microssatélites foram otimizadas usando géis de poliacrilamida desnaturante aderidos à placas de vidro. 


\subsection{Material e Métodos}

\subsubsection{Extração do DNA e condições da PCR}

DNA genômico total foi extraído a partir de folhas de 35 genótipos de Musa, compreendendo cultivares triplóides, tetraplóides e uma cultivar diplóide, empregandose um procedimento modificado adaptado de Doyle \& Doyle (1990). O DNA foi quantificado for fluorimetria (DyNA Quant 2000 Fluorometer, Amersham Pharmacia Biotech, Buckinghamshire, UK). Reações de amplificação foram realizadas conforme descrito por Lagoda et al. (1998b) com pequenas modificações. O volume das reações de amplificação foi $25 \mu$ l, contendo 50 ng de DNA genômico; $50 \mathrm{mM} \mathrm{KCl;} 10 \mathrm{mM}$ Tris$\mathrm{HCl}(\mathrm{pH} 8.8) ; 0.1 \%$ Triton-X; $1.5 \mathrm{mM} \mathrm{MgCh} ; 100 \mu \mathrm{M}$ de cada dNTPs; $0.2 \mu \mathrm{M}$ de cada primer AGMI 24 e AGMI 25 (Lagoda et al., 1998b) e 1.5 unidades de Taq polymerase (Life Technologies do Brasil, São Paulo, SP, Brasil). Os primers SSRs foram sintetizados pela Life Technologies do Brasil baseados em seqüências obtidas por Lagoda et al. (1998b). Amplificações foram conduzidas em termociclador Perkin Elmer modelo 9700 (Applied Biosystems, Foster City, CA, USA), empregando-se um programa 'touchdown', com ciclo inicial de $94{ }^{\circ} \mathrm{C}$ por $3 \mathrm{~min}$, seguido de 9 ciclos a $40 \mathrm{~s}$ a $94^{\circ} \mathrm{C}$; $40 \mathrm{~s}$ a $60{ }^{\circ} \mathrm{C}, 60 \mathrm{~s}$ a $72{ }^{\circ} \mathrm{C}$, reduzindo um grau a cada ciclo, seguido de 25 ciclos de 40 s a $94^{\circ} \mathrm{C}, 40 \mathrm{~s}$ a $50{ }^{\circ} \mathrm{C}$, e $60 \mathrm{~s}$ a $72^{\circ} \mathrm{C}$.

\subsubsection{Eletroforese}

- Tratar a placa de vidro menor $(33,3$ x 39,4 cm) com $4 \mu 1$ de metacriloxipropiltrimetoxisilano (PlusOne Bind-Silane, cat. \# 17-1330-01; Amersham Pharmacia Biotech) em $1 \mathrm{~mL}$ de etanol-ácido acético (0,5\% de ácido acético glacial em 95\% de de etanol), para colar o gel à placa de vidro. Deixar secar por 5 minutos e remover o excesso usando papel umedecido em etanol 95\%;

- Tratar o vidro maior $(33,3$ x $41,9 \mathrm{~cm})$ com $1 \mathrm{~mL}$ de solução a $2 \%$ de dimetildiclorosilano em octametil ciclo-octasilano (PlusOne Repel-Silane ES, cat \# 17-1332-01, Amersham Pharmacia Biotech) para permitir a separação das 
placas. Deixar secar por 5 minutos e remover o excesso com papel umedecido em água destilada.

- Preparar uma solução 30\% de acrilamida com 29 g de acrilamida e $1 \mathrm{~g}$ de metilenobisacrilamida, em volume final de $100 \mathrm{~mL}$ em água mili-Q autoclavada;

- Preparar uma solução de uréia:acrilamida, misturando $100 \mathrm{~mL}$ da solução $30 \%$ de acrilamida, $100 \mathrm{~mL}$ de TBE 5X (445 mM Tris-base; $445 \mathrm{mM}$ ácido bórico, 10 mM EDTA), e 219 g de uréia. Adicionar água mili-Q autoclavada para um volume final de $500 \mathrm{~mL}$, filtrar em papel de filtro e armazená-la a $4^{\circ} \mathrm{C}$ em frasco escuro;

- Preparar o gel (6\% de poliacrilamida; 7M uréia), misturando $50 \mathrm{~mL}$ da solução uréia:acrilamida em TBE, com $200 \mu \mathrm{L}$ de solução fresca a 10\% de persultato de sódio e $84 \mu \mathrm{L}$ de TEMED. Aplicar esta solução às placas de vidros já montadas com os espaçadores $(0,4 \mathrm{~mm}$ de espessura) usando o aparato de seqüenciamento SQ3 (Amersham Pharmacia Biotech). Esperar 60 minutos até o gel polimerizar.

- Correr o gel de seqüenciamento a $60 \mathrm{~W}(42 \mathrm{~mA} ; 1500 \mathrm{~V})$ por 60 minutos, ou até a temperatura das placas de vidro atingir $55^{\circ} \mathrm{C}$, em tampão TBE $1 \mathrm{X}$ ( $89 \mathrm{mM}$ Tris; 89 mM ácido bórico, 2 mM EDTA);

- Adicionar 12,5 $\mu \mathrm{L}$ de tampão desnaturante $(10 \mathrm{mM} \mathrm{NaOH} ; 0,05 \%$ xylenocyanol [p/v]; 0,05\% de azul de bromofenol [p/v]; $20 \mathrm{mM}$ de EDTA em formamida), aos $25 \mu \mathrm{L}$ da reação de amplificação. Quando usar diferentes volumes de reação de PCR, manter a mesma proporção de tampão desnaturante.

- Desnaturar as amostras por 3 minutos a $94^{\circ} \mathrm{C}$ no termociclador. Colocar as amostras imediatamente no gelo.

- Aplicar as amostras $(8 \mu \mathrm{L})$ no gel o mais rápido possível. Correr o gel a $60 \mathrm{~W}$ por 80-100 minutos a $50-55^{\circ} \mathrm{C}$. 


\subsubsection{Coloração com Prata}

Os géis foram coloridos com prata empregando-se três métodos, de acordo com os passos descritos na Tabela 1. O protocolo desenvolvido por Bassam et al. (1991) foi seguido exatamente como descrito. O método descrito por Sanguinetti et al. (1994) foi ligeiramente modificado, com alteração no tempo para melhorar a detecção. O método melhorado adaptado de Beidler et al. (1982) foi otimizado. Todos os reagentes empregados para a coloração foram de grau analítico, tanto da Mallinckrodt Baker S.A. (Xalostoc, México) (etanol, ácido nítrico e carbonato de sódio) e da Merck (nitrato de prata, hidróxido de sódio, formaldeído). Todas as soluções foram preparadas usando-se água destilada ultrapura. As placas de vidro foram cuidadosamente agitadas em shaker durante o processo de coloração. Proceder a coloração da seguinte maneira:

- Cuidadosamente, desmontar o aparato do gel, separando as placas de vidro;

- Colocar a placa de vidro com o gel aderido a ela em um recipiente de plástico,

- Aplicar $1000 \mathrm{~mL}$ da solução fixadora (10\% etanol, $1 \%$ ácido acético) e agitar em shaker por 10 minutos,

- $\quad$ Lavar o gel com 1000 mL de água destilada por 1 minuto;

- Pré-tratar o gel (oxidar) com $1000 \mathrm{~mL}$ de solução de ácido nítrico a 1,5\% por 3 minutos,

- $\quad$ Lavar o gel com 1000 mL de água destilada por 1 minuto;

- Colorir o gel com $1000 \mathrm{~mL}$ de solução de nitrato de prata a 0,2\% por 20 minutos, agitando cuidadosamente em shaker;

- Lavar o gel duas vezes com 1000 mL de água destilada por 30segundos;

- Revelar o gel aplicando inicialmente, $250 \mathrm{~mL}$ da solução reveladora $\left(30 \mathrm{gL}^{-1}\right.$ $\mathrm{Na}_{2} \mathrm{CO}_{3} ; 0,54 \mathrm{~mL}$ por litro de formaldeído a $37 \%$ ) gelada (i.e. $12^{\circ} \mathrm{C}$ ), agitando cuidadosamente até a solução se tornar escura. Substituí-la com o restante 750 mL da solução, agitar por 4-7 minutos, até as bandas adquirirem a intensidade desejada (aproximadamente 5 minutos). Remover a solução reveladora.

- Parar a revelação adicionando $1000 \mathrm{~mL}$ de solução de ácido acético a 5\%, por 5 minutos. 
- Lavar o gel em água destilada.

- Secar ao ar livre, fotografar ou escanear.

Tabela 1. Resumo dos passos empregados nos três métodos de coloração com prata.

\begin{tabular}{|c|c|c|c|}
\hline Passo & $\begin{array}{c}\text { Procedimento melhorado } \\
\text { (adaptado Beidler et al. } \\
\text { 1982) }\end{array}$ & Bassam et al. 1991 & Sanguinetti et al. 1994 \\
\hline 1. Fixação & $\begin{array}{l}10 \% \text { Etanol, } 1 \% \text { ácido } \\
\text { acético; } 10 \mathrm{~min}\end{array}$ & $\begin{array}{l}10 \% \text { ácido acético; } 20 \\
\text { min }\end{array}$ & $\begin{array}{l}10 \% \text { etanol; } 0.5 \% \text { ácido } \\
\text { acético; } 20 \mathrm{~min}\end{array}$ \\
\hline 2. Lavagem & $\mathrm{H}_{2} \mathrm{O} ; 1$ min & - & - \\
\hline $\begin{array}{l}\text { 3.Pré- } \\
\text { tratamento }\end{array}$ & $1.5 \%$ ácido nítrico; $3 \mathrm{~min}$ & - & - \\
\hline 4. Lavagem & $\mathrm{H}_{2} \mathrm{O} ; 1$ min & $\mathrm{H}_{2} \mathrm{O} ; 2$ min; 3 vezes & - \\
\hline 5. Coloração & $0.2 \% \mathrm{AgNO}_{3} ; 20 \mathrm{~min}$ & $\begin{array}{l}0.1 \% \mathrm{AgNO}_{3} ; 1.5 \mathrm{~mL} \\
37 \% \text { formaldeído litro } \\
30 \mathrm{~min}\end{array}$ & $0.2 \% \mathrm{AgNO}_{3} ; 30 \mathrm{~min}$ \\
\hline 6. Lavagem & $\mathrm{H}_{2} \mathrm{O} ; 30 \mathrm{~s} ; 2$ vezes & $\mathrm{H}_{2} \mathrm{O} ; 20 \mathrm{~s}$ (opcional) & - \\
\hline 7. Revelação & $\begin{array}{l}30 \mathrm{~g} \mathrm{l}^{-1} \mathrm{Na}_{2} \mathrm{CO}_{3} ; 0.54 \mathrm{~mL} \\
37 \% \text { formaldeído litro } \\
4-7 \text { min. }\end{array}$ & $\begin{array}{l}3 \% \mathrm{Na}_{2} \mathrm{CO}_{3} ; 1.5 \mathrm{ml} 37 \% \\
\text { formaldeído litro }{ }^{-1} ; 2 \mathrm{mg} \\
\mathrm{Na}_{2} \mathrm{~S}_{2} \mathrm{O}_{3} .5 \mathrm{H}_{2} \mathrm{O} \text { litro } \\
\text { min. }\end{array}$ & $\begin{array}{lll}3 \% \mathrm{NaOH} ; & 5 \mathrm{~mL} & 37 \% \\
\text { formaldeído } & \text { litro }^{-1} ; & 5-10 \\
\text { min } & \end{array}$ \\
\hline 8. Finalização & $5 \%$ ácido acético; 5 min & $10 \%$ ácido acético; 5 min & $\begin{array}{l}10 \% \text { etanol; } 0.5 \% \text { ácido } \\
\text { acético }\end{array}$ \\
\hline
\end{tabular}

\subsection{Resultados e Discussão}

DNA de 35 genótipos de banana (cultivares diplóides, triplóides e tetraplóides) foram amplificados por PCR empregando-se o primer AGMI 24/25 (Lagoda et al., 1998b). Amostras da mesma reação de amplificação foram aplicadas em três géis de poliacrilamida idênticos. Todos os três métodos de coloração com prata foram empregados para detecção do polimorfismo SSR. Os três métodos exibiram o mesmo padrão de bandas, com alelos idênticos (Figura 1). Entretanto, os métodos diferiram em relação a sensibilidade e contraste. O método melhorado baseado em Beidler et al. (1982) apresentou sensibilidade e contraste similar ao método proposto por Bassam et al. (1991), utilizado por Lagoda et al. (1998a), porém, com menor background, devido 


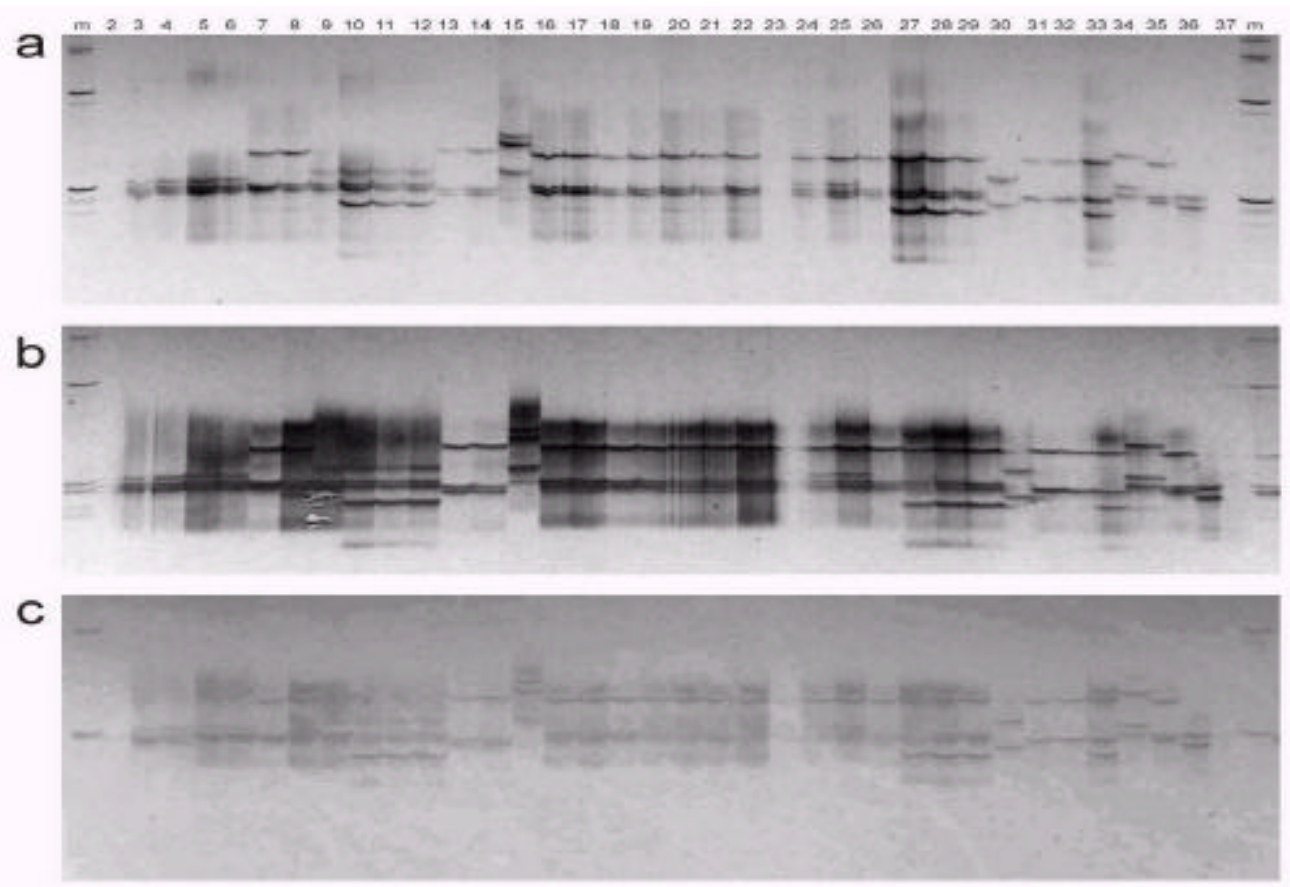

Figura 1 - Sensibilidade dos três métodos de coloração com prata no polimorfismo microssatélite em Musa, empregando-se o primer AGMI 24/25 e separado em géis desnaturante de poliacrilamida a $6 \%$. (a) Método melhorado baseado em Beidler et al. (1982); (b) método de Bassam et al. (1991) e (c) método de Sanguinetti et al. (1994). Linha m. 123 ladder; linha 2. 'Williams'; 3. 'Grand Naine'; 4. 'Nanica'; 5. Nanicão'; 6. 'PBN'; 7. 'Ouro da Mata'; 8. 'Branca'; 9. 'Gros Michel'; 10. 'Bucaneer'; 11. 'Ambrosia'; 12. 'Calypson'; 13. Mysore'; 14. Thap Maeo'; 15. 'Prata Jau'; 16. 'Prata'; 17. 'Prata'; 18. 'Prata Santa Maria'; 19. 'Prata Ponta-Aparada'; 20. 'Enxerto'; 21. 'Prata Anã'; 22. 'Pioneira'; 23. 'FHIA 01'; 24. 'FHIA 18'; 25. 'SH3640'; 26. 'Pacovan'; 27. 'PV42-142'; 28. 'PV42-85'; 29. 'PV42-68'; 30. Caipira'; 31. 'Maçã'; 32. Yangambi km 2'; 33. 'YB42-21'; 34. 'Terra'; 35. 'Prata Porte Baixo'; 36. 'Lidi'; 37. Controle negativo (sem DNA). Amostras 2-6, 9 e 30 possuem constituição genômica AAA (3x); amostras 10-12 são AAAA (4x); 8, 13-21, 26, 31, 32, 34, e 35 genoma AAB (3x); 7, 22-25, 27-29, e 33 genoma AAAB (híbridos 4x); 36 AA diplóide (2x). Amostras ns linhas 2 e 27 não amplificaram. 
provavelmente a menor concentração de formaldeído empregada. $\mathrm{O}$ método desenvolvido por Sanguinetti et al. (1994) apresentou a menor sensibilidade, com um background amarelo forte, mas com bandas visíveis e discretas. O maior problema com este método foi a interferência da solução reveladora contendo $\mathrm{NaOH}$, a qual causou o descolamento do gel da placa de vidro.

Amostras contendo diluições seriais idênticas de produtos amplificados foram aplicadas em cada gel com o objetivo de se testar a sensibilidade de cada método (Figura 2). Amostras controle contendo uma concentração de DNA de 24 ng em $8 \mu \mathrm{L}$ estimada por fluorimetria, e volumes decrescentes $(4 \mu \mathrm{l}, 2 \mu \mathrm{l}$ and $1 \mu \mathrm{l})$ foram aplicadas. O método melhorado foi bastante sensível e apresentou o menor background, detectando bandas nítidas e discretas mesmo com o menor volume. O método proposto por Sanguinetti et al. (1994) foi capaz de detectar apenas as amostras com $4 \mu \mathrm{l}$.

A preparação e o manuseio das soluções foram as mesmas para todos os métodos. A solução fixadora pode ser reutilizada por três vezes, enquanto que as soluções de oxidação (ácido nítrico) e a finalizadora (ácido acético), podem ser reutilizadas por cinco vezes. A solução de nitrato de prata pode ser reutilizada por duas vezes, sem comprometer a sensibilidade, cuidando-se armazená-las em vidro escuro na temperatura ambiente.

Anteriormente, a análise do polimorfismo SSRs era realizada em géis não desnaturantes, de tamanho 20 × $20 \mathrm{~cm}$ e espessura de $1,5 \mathrm{~mm}$. Devido ao tamanho do gel e espessura para suportar as manipulações no processo de coloração, ambas as superfícies eram livres de vidros e os géis eram corados de acordo com a metodologia descrita por Sanguinetti et al. (1994). Entretanto, quando grandes géis de seqüenciamento $(33,3 \times 39,4 \mathrm{~cm})$ foram usados, este método de coloração não foi apropriado devido ao tamanho e espessura $(0,4 \mathrm{~mm})$.

Lagoda et al. (1998a) relataram o polimorfismo microssatélite em banana baseado em géis desnaturantes pequenos $(10 \times 12 \mathrm{~cm})$, aderidos a filmes de poliéster, corados com prata usando o método de Bassam et al. (1991). O mesmo método apresentou bons resultados quando testado em grandes géis de seqüenciamento aderidos à uma superfície de vidro. Entretanto, a reação de revelação foi muito rápida para um 


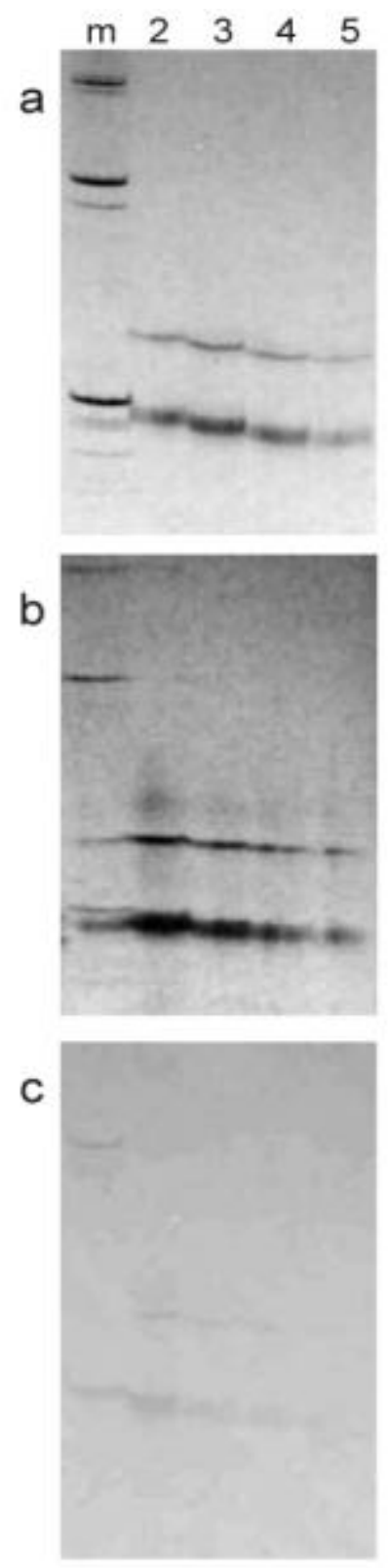

Figura 2 - Sensibilidade na detecção da amplificação de SSR na cultivar de banana 'Ouro da Mata' (genomaAAAB), empregando-se o par de primer AGMI 24/25 com os três métodos de coloração com prata, em géis de poliacrilamida $6 \%$ desnaturante. Volumes decrescentes de produtos amplificados foram carregados por linha. Linha m. 123 ladder; Linha 2. $8 \mu \mathrm{l} ; 3.4 \mu \mathrm{l}$; 4. $2 \mu \mathrm{l} ; 5.1 \mu \mathrm{l}$. (a) método melhorado baseado em Beidler et al. (1982); (b) método de Bassam et al. (1991); (c) método de Sanguinetti et al. (1994). 
controle seguro do contraste, mesmo usando as soluções em baixas temperaturas. $\mathrm{O}$ método de coloração melhorado baseado em Beidler et al. (1982) apresentou várias vantagens. Um grande número de amostras podem ser analisadas em um único gel, permitindo a comparação direta dos alelos. Por serem finos, mas largos, os géis de seqüenciamento utilizam um volume comparável de poliacrilamida e outros reagentes para análise de um grande número de amostras (cerca de 96 em comparação a 20). A maioria dos reagentes de coloração podem ser reutilizados, sem comprometer a qualidade. A alta sensibilidade na detecção dos fragmentos permite que pequenos volumes de amostra sejam carregados, e conseqüentemente, um volume reduzido da reação de PCR é requerido (cerca de $13 \mu \mathrm{L}$ ).

O método melhorado baseado em Beidler et al. (1982) tem sido rotineiramente usado em nosso laboratório para análise do polimorfismo baseado em AFLP e SSR em várias culturas tropicais Theobroma grandiflorum (cupuaçu); T. cacao (cacaueiro); cana-de-açúcar; feijão, maçã e citrus], com resultados satisfatórios. É um método simples e seguro, e não apresenta os riscos associados ao uso de radioisótopos. Entretanto, a solução de nitrato de prata deve ser devidamente descartada para evitar contaminação ambiental.

\subsection{Conclusões}

- O procedimento de coloração com prata apresentado neste trabalho mostrou-se eficiente na detecção do polimorfismo microssatélite e AFLP em várias espécies;

- Além de ser um procedimento seguro e de baixo custo, a reação de amplificação, eletroforese e coloração pode ser facilmente conduzida em um único dia. 


\section{VARIABILIDADE GENÉTICA EM CULTIVARES DE BANANEIRA (Musa SPp.) REVELADA POR MARCADORES MICROSSATÉLITES}

\section{S. CRESTE ${ }^{1}$; A. TULMANN-NETO²; S.O. SILVA³ ; A. FIGUEIRA ${ }^{2}$.}

1. Departamento de Genética - ESALQ/USP - Av. Pádua Dias, 11 CP 83, Piracicaba SP, 13400-970. Brasil.

2. Centro de Energia Nuclear na Agricultura - CENA/USP - Av. Centenário, 303, CP 96, Piracicaba - SP. 13400-970. Brasil

3. Centro Nacional de Pesquisa em Mandioca e Fruticultura - CNPMF/EMBRAPA Rua Embrapa, s/n, CP 007, Cruz das Almas - BA ,44380-000. Brasil.

Palavras-chave: Banana, coloração com prata, microssatélite, Musa, SSRs, 


\section{Resumo}

Trinta e cinco genótipos de bananeira, compreendendo cultivares triplóides e híbridos tetraplóides, representantes de diferentes grupos genômicos, foram caracterizados por marcadores microssatélites. Um total de 33 pares de primers, desenvolvidos para banana foram testados. Onze pares de primers amplificaram produtos claros e distintos, a partir dos quais 67 alelos foram identificados. $\mathrm{O}$ número de alelos por primer variou de 4 a 8, com média de 6,1. A análise fenética obtida mostrou concordância com a classificação morfológica, dividindo os genótipos em dois grandes grupos: o primeiro, contendo fundamentalmente os genótipos que possuem apenas o genoma A, e o segundo, todos os genótipos resultantes da hibridação natural ou artificial entre Musa acuminata e Musa balbisiana. Dentro de cada grupo, a união entre os genótipos ocorreu com base no nível de ploidia, grupo genômico e subgrupo. Os primers empregados foram altamente informativos, alguns, geraram fingerprinting únicos para cada grupo genômico, como também foram capazes de discriminar genótipos com classificação duvidosa ('Prata Jau'). Mutantes somáticos foram eventualmente discriminados de seu clone original. Alta similaridade genética foi observada entre os híbridos tetraplóides compartilhando um mesmo parental feminino, os quais exibiram também, distorções na proporção de alelos doados pelo progenitor triplóide. Uma alta proporção de alelos multiplex foi observada entre os genótipos triplóides e tetraplóides, e suas conseqüências consideradas.

\section{Summary}

Thirty-five banana genotypes, including triploid cultivars and tetraploid hybrids, representing the various genomic groups were characterized by microsattelite markers. A total of 33 primers, originally developed for banana were tested. Eleven primer pairs amplified discrete and clear bands, and 67 alleles were identified. The number of alleles amplified by primer varied from 4 to 8 , with an average of 6.1 . The phenetic analysis agreed with the morphological classification, separating the genotypes into two main 
groups. One group was composed basically by all genotypes containing only A genome, whreras the otehr group had all genotypes resulting from natural or artificial hybridization between Musa acuminata and Musa balbisiana. Within each group, genotypes were clustered according to ploidy level, genomic group and subgroup. The primers used were highly informative, with some amplifying unique fingerprinting for each genomic group, and were able to segregate genotypes with dubious classification (e.g. 'Prata Jau'). Somatic mutants were seldom distinguished from original clone. High genetic similarity was observed between tetraploid hybrids sharing the same female parent. The proportion of alleles donated by triploids female genitors were distorted. A large number of multiplex alleles were observed between triploid and tetraploid genotypes, and its consequences were considered.

\subsection{Introdução}

As maioria das bananeiras produtoras de frutos comestíveis originou-se a partir da hibridação intra e interespecífica das espécies selvagens, Musa acuminata (genoma A) e Musa balbisiana (genoma B) (Simmonds \& Shepherd, 1955). Grande parte das cultivares é triplóide, sendo que diplóides e tetraplóides ocorrem com menor frequiência. O intercruzamento de espécies e subespécies levou ao aparecimento de esterilidade, uma característica selecionada pelo homem juntamente com partenocarpia e propagação vegetativa (Simmonds, 1995).

Taxonomicamente, as cultivares e híbridos são classificados a partir de um conjunto de descritores morfológicos que permite classificá-los em vários grupos genômicos, sendo os principais de constituição AA, AAA, AAB, ABB, embora sejam possíveis combinações AB, AAAB, AABB, ABBB. (Stover \& Simmonds, 1987). Cultivares ou híbridos obtidos a partir de mutações de um único clone constituem os chamados 'subgrupos'. A produção de banana para exportação concentra-se nas cultivares do subgrupo 'Cavendish' de constituição genômica AAA, enquanto que um grande número de cultivares e 'landraces' de constituição genômica AAA, AAB e ABB são cultivados para consumo local em diversas regiões do mundo. 
O Brasil é o segundo produtor mundial de banana, porém, toda a produção destina-se ao mercado interno, cuja preferência se dá por cultivares do grupo AAB subgrupo 'Prata'. Embora exista um grande número de cultivares, a baixa produtividade dos clones, bem como a falta de resistência a fatores bióticos e abióticos constituem os maiores entraves da bananicultura no país (Silva et al., 1999). Além disso, a ocorrência de denominações locais e ambíguas bem como a alta mutabilidade de alguns clones limita o conhecimento dos recursos genéticos existentes.

Apesar da grande esterilidade da maioria dos clones triplóides, muitos deles produzem sementes ao serem usados como genitor feminino em cruzamentos com diplóides na geração de híbridos tetraplóides. A seleção dos melhores diplóides e triplóides a serem usados nos programas de hibridação é baseada na caracterização morfológica (Silva et al., 1998).

Recentemente, marcadores moleculares têm sido empregados na caracterização e na avaliação da variabilidade genética em Musa, incluindo RFLP (Restriction Fragment Length Polymorphism; Gawel et al., 1992, Fauré et al., 1994), RAPD (Random Amplified Polymorphic DNA; Bhat e Jarret, 1995; Pillay et al., 2000); AFLP (Amplified Fragment Length Polymorphism; Loh et al., 2000) e microssatélites ou SSRs (Simple Sequence Repeats; Lagoda et al., 1998a; Crouch et al., 1998; Kaemmer et al., 1997; Grapin et al., 1998).

Dentre estas técnicas, os microssatélites têm se constituído no melhor marcador, pois são altamente polimórficos, mostram herança co-dominante, possuem fácil interpretação e são amplificados via PCR. Microssatélites são elementos polimórficos abundantes em genomas nucleares e consistem de seqüências curtas de DNA, usualmente menores que quatro nucleotídeos de comprimento, repetidas em linha ou tandem (Wang et al., 1994). Estas regiões estão uniformemente distribuídas por todo o genoma eucariótico, geralmente inseridas em seqüências de cópia única (Tautz, 1989). Fragmentos contendo microssatélites podem ser amplificados via PCR usando primers complementares às regiões que flanqueiam estas repetições, sendo que o polimorfismo entre indivíduos surge de diferenças no número de repetições. Em contraste com o RAPD, os microssatélites requerem o prévio conhecimento da seqüência de DNA. 
Crouch et al. (1998) desenvolveram primers específicos para 24 loci, enquanto que Lagoda et al. (1998b) desenvolveram para outros 47 loci.

O objetivo do presente trabalho foi caracterizar 35 genótipos de bananeira, incluindo cultivares comerciais, 'landraces' e híbridos tetraplóides, empregando-se os primers desenvolvidos para banana.

\subsection{Material e Métodos}

\subsection{Material}

\subsubsection{Material Vegetal}

Os 35 genótipos empregados na avaliação do polimorfismo incluem cultivares comerciais, 'landraces' e híbridos tetraplóides, mantidos no banco de germoplasma de banana da Embrapa Mandioca e Fruticultura, Cruz das Almas, BA, Brasil. Como controle foi usada a cultivar diplóide Lidi' (AA). Informações sobre cada genótipo encontram-se na Tabela 1.

\subsubsection{Primers microssatélite}

Um total de 33 pares de primer foram testados, compreendendo 27 desenvolvidos por Crouch et al., (1998), [série Ma], obtidos da Research Genetics Inc. (Huntsville, AL, EUA) e 6 pares de primer desenvolvidos por Lagoda et al.(1998b).[série AGMI], sintetizados pela Life Technologies do Brasil (São Paulo, Brasil). Detalhes dos primers empregados estão listados na Tabela 2.

\subsubsection{Métodos}

\subsubsection{Extração do DNA e condições da PCR}

DNA genômico foi extraído a partir de folhas jovens, empregando-se o método CTAB proposto por Doyle e Doyle (1990), e quantificado for fluorimetria (DyNA Quant 2000 Fluorometer, Amersham Biociences, Buckinghamshire, UK). 
Tabela 1. Cultivares, grupos genômicos e subgrupos dos genótipos de banana avaliados por marcadores microssatélites.

\begin{tabular}{|c|c|c|c|}
\hline Genótipo & $\begin{array}{c}\text { Grupo } \\
\text { genômico }\end{array}$ & Subgrupo & Tipo \\
\hline Williams & AAA & Cavendish & Cultivar \\
\hline Grande Naine & AAA & Cavendish & Cultivar \\
\hline Nanica & AAA & Cavendish & Cultivar \\
\hline Nanicão & AAA & Cavendish & Cultivar \\
\hline $\mathrm{PBN}$ & AAA & Cavendish & Mutante \\
\hline Ouro da Mata & $\mathrm{AAAB}$ & - & landrace \\
\hline Branca Santa Catarina & $\mathrm{AAB}$ & Prata & landrace \\
\hline Gros Michel & AAA & Gros Michel & Cultivar \\
\hline Bucaneer & AAAA & - & Híbrido (High Gate x $2 n$ ) \\
\hline Ambrosia & AAAA & - & Híbrido(High Gate x 2n) \\
\hline Calipson & AAAA & - & Híbrido (High Gate x $2 n$ ) \\
\hline Mysore & $\mathrm{AAB}$ & - & Cultivar \\
\hline Thap Maeo & $\mathrm{AAB}$ & - & Cultivar \\
\hline Prata Jau & $\mathrm{AAB}$ & Prata & landrace \\
\hline Prata Porte Baixo & $\mathrm{AAB}$ & Prata & Cultivar \\
\hline Prata & $\mathrm{AAB}$ & Prata & Cultivar \\
\hline Prata (Cruz das Almas) & $\mathrm{AAB}$ & Prata & Cultivar \\
\hline Prata Santa Maria & $\mathrm{AAB}$ & Prata & Cultivar \\
\hline Prata Ponta Aparada & $\mathrm{AAB}$ & Prata & Cultivar \\
\hline Enxerto & $\mathrm{AAB}$ & - & Cultivar \\
\hline Prata Anã & $\mathrm{AAB}$ & - & Cultivar \\
\hline Pioneira & $\mathrm{AAAB}$ & - & Híbrido (Prata Anã x Lidi) \\
\hline FHIA-01 & $\mathrm{AAAB}$ & - & Híbrido (Prata Anã x 2n) \\
\hline FHIA-18 & $\mathrm{AAAB}$ & - & Híbrido (Prata Anã x 2n) \\
\hline SH3640 & $\mathrm{AAAB}$ & - & Híbrido (Prata Anã x 2n) \\
\hline Pacovan & $\mathrm{AAB}$ & Prata & Cultivar \\
\hline PV42-142 & $\mathrm{AAAB}$ & - & Híbrido (Pacovan x M53) \\
\hline PV42-85 & AAAB & - & Híbrido (Pacovan x M53) \\
\hline PV42-68 & $\mathrm{AAAB}$ & - & Híbrido (Pacovan x M53) \\
\hline Caipira & AAA & - & Cultivar \\
\hline Maçã & $\mathrm{AAB}$ & - & Cultivar \\
\hline Yangambi Km 2 & $\mathrm{AAB}$ & - & Cultivar \\
\hline YB42-21 & $\mathrm{AAAB}$ & - & Híbrido (Yangambi Km2 x $2 n$ ) \\
\hline Terra & $\mathrm{AAB}$ & Terra & Cultivar \\
\hline Lidi & $\mathrm{AA}$ & - & Cultivar \\
\hline
\end{tabular}


Tabela 2. Primers testados na caracterização dos 35 genótipos de bananeira.

\begin{tabular}{|c|c|c|c|c|}
\hline Primer & Seqüência (5'-3’) & Produto $^{\mathrm{a}}(\mathrm{pb})$ & $\operatorname{Tm}\left({ }^{\circ} \mathrm{C}\right)$ & Resultado $^{\mathrm{b}}$ \\
\hline Ma $1 / 2$ & gatgatggtgagaggctgata & 142 & 58 & $\mathrm{f}$ \\
\hline Ma $1 / 3$ & $\begin{array}{l}\text { ggtcggtatgggaagcacc } \\
\text { ctgccttccattcttgctgt } \\
\text { cccgcccaaaagttaagatc }\end{array}$ & 160 & 57 & $\mathrm{np}$ \\
\hline Ma $1 / 5$ & $\begin{array}{l}\text { agatggcggagggaagag } \\
\text { ccggatccaagcttatcga }\end{array}$ & 120 & 56 & $\mathrm{np}$ \\
\hline Ma $1 / 6$ & $\begin{array}{l}\text { caagaacccaaccggtcac } \\
\text { ttgtcatcaccatccgtcatt }\end{array}$ & 139 & 57 & $\mathrm{np}$ \\
\hline Ma1/16 & $\begin{array}{l}\text { cccectttcctcttttgc } \\
\text { cccecetttcctcttttgc }\end{array}$ & 150 & 58 & $\mathrm{np}$ \\
\hline Ma 1/17 & $\begin{array}{l}\text { aggcggggaatcggtaga } \\
\text { ggcgggagacagatggagt }\end{array}$ & 124 & 57 & + \\
\hline Ma 1/18 & $\begin{array}{l}\text { tttgcctggttgggetga } \\
\text { cccccett } 1 \text { cetcttttgc }\end{array}$ & 150 & 58 & np \\
\hline Ma 1.24 & $\begin{array}{l}\text { gagcccattaagctgaaca } \\
\text { ccgacagtcaacatacaataca }\end{array}$ & 172 & 56 & $\mathrm{f}$ \\
\hline Ma 1.27 & $\begin{array}{l}\text { tgaatcccaagtttggtcaag } \\
\text { caaaacacatgtccccatctc }\end{array}$ & 126 & 56 & $\mathrm{f}$ \\
\hline Ma 1.31 & $\begin{array}{l}\text { cacagtaaacaaggaggtgatc } \\
\text { cgacagatttaagattggatca }\end{array}$ & 133 & 56 & np \\
\hline Ma 1.32 & $\begin{array}{l}\text { ggaacaggtgatcaaagtgtga } \\
\text { ttgatcatgtgccgctactg }\end{array}$ & 187 & 58 & + \\
\hline Ma $2 / 3$ & $\begin{array}{l}\text { ggacaatcttacccattgatc } \\
\text { cccaaactctctctccetc }\end{array}$ & 246 & 57 & np \\
\hline Ma $2 / 4$ & $\begin{array}{c}\text { ctcctttgtgagctcggcatt } \\
\text { agggtccaaggaaactcctcccaa }\end{array}$ & 175 & 58 & - \\
\hline Ma 2/7 & $\begin{array}{l}\text { tgaatcccaagtttggtcaaga } \\
\text { ccaactcttgtccetcacttca }\end{array}$ & 89 & 55 & $\mathrm{np}$ \\
\hline Ma 2/12 & $\begin{array}{l}\text { cgcatgctccetctaagactc } \\
\text { tccgatcttccgecaagt }\end{array}$ & 160 & 58 & - \\
\hline $\mathrm{Ma} 2 / 23$ & $\begin{array}{l}\text { attcggacaatcttaccca } \\
\text { cccaaactctctcectc }\end{array}$ & 250 & 57 & np \\
\hline Ma 3/1 & $\begin{array}{l}\text { cacgtaaacaaggaggtgac } \\
\text { cgacagatttaagattggata }\end{array}$ & 133 & 56 & $\mathrm{np}$ \\
\hline $\mathrm{Ma} 3 / 60$ & $\begin{array}{l}\text { tggctgacaattacatgaca } \\
\text { gcggactgtggtgtgt }\end{array}$ & 133 & 56 & np \\
\hline Ma 3/68 & $\begin{array}{l}\text { gaatcactgatcaccactaagaa } \\
\text { ggggttttgttaccttagatatg }\end{array}$ & 244 & 57 & np \\
\hline Ma 3/90 & $\begin{array}{l}\text { gcacgaagaggcatcac } \\
\text { ggccaaatttgatggact }\end{array}$ & 140 & 56 & + \\
\hline Ma 3/103 & $\begin{array}{l}\text { tcgcctctctttagctctg } \\
\text { tgttggaggatctgagattg }\end{array}$ & 152 & 56 & + \\
\hline Ma 3/127 & $\begin{array}{l}\text { tcgctctaatcggattatctc } \\
\text { tctccggatccaagctta }\end{array}$ & nd & 56 & $\mathrm{np}$ \\
\hline
\end{tabular}


Tabela 2. Primers testados na caracterização dos 35 genótipos de bananeira.

\begin{tabular}{|c|c|c|c|c|}
\hline Primer & Seqüência (5' - 3') & Produto $^{\mathrm{a}}(\mathrm{pb})$ & $\operatorname{Tm}\left({ }^{\circ} \mathrm{C}\right)$ & Resultado \\
\hline Ma 3/130 & $\begin{array}{l}\text { attggggacagggacgat } \\
\text { ccggatccaagcttatcga }\end{array}$ & 198 & 58 & $\mathrm{np}$ \\
\hline Ma 3/131 & $\begin{array}{l}\text { tggaaatcaaagaaggcaagtc } \\
\text { ggagctctccggatccaa }\end{array}$ & 123 & 56 & np \\
\hline $\mathrm{Ma} 3 / 132$ & $\begin{array}{l}\text { aacgcgaatgtgtgttttca } \\
\text { tccetcttcaaccaacgcac }\end{array}$ & 160 & 57 & + \\
\hline Ma 3/139 & $\begin{array}{l}\text { actgctgctctccacctcaac } \\
\text { gtcccccaagaaccatatgatt }\end{array}$ & nd & 55 & + \\
\hline Ma 3/161 & $\begin{array}{l}\text { aaacgtgaaacgacagcttctg } \\
\text { tccggcttcgaattgaatg }\end{array}$ & 188 & 58 & + \\
\hline AGMI 24/25 & $\begin{array}{l}\text { tttgatgtcacaatgggttcc } \\
\text { ttaaaggtgggttagcattagg }\end{array}$ & 248 & 55 & + \\
\hline AGMI 93/94 & $\begin{array}{l}\text { aacaactaggatggtaatgtgtgga } \\
\text { gatctgaggatggttctgttggag }\end{array}$ & 128 & 55 & + \\
\hline AGMI 121/122 & $\begin{array}{l}\text { cagtttggccgettgatctt } \\
\text { ggggtcaacatgttaagttct }\end{array}$ & 333 & 48 & + \\
\hline AGMI 157/158 & $\begin{array}{l}\text { tcaagaatcgccgaattac } \\
\text { caagacgaaggaccattgatgtt }\end{array}$ & 143 & 54 & - \\
\hline AGMI 67/68 & $\begin{array}{l}\text { ataccttctcccgttcttcttc } \\
\text { tggaaacccaatcattgatc }\end{array}$ & nd & 50 & + \\
\hline AGMI 161/162 & $\begin{array}{l}\text { tgaggcggggaatcggta } \\
\text { ggcgggagacagatggagtt }\end{array}$ & nd & 50 & - \\
\hline
\end{tabular}

Nota: ${ }^{a}$ tamanho esperado do alelo amplificado de acordo com a seqüência do fragmento usado no desenho dos primers; nd = tamanho não divulgado; ${ }^{\mathrm{b}}$ polimorfismo em cultivares de bananeira + , polimórfico; - , monomórfico; np, nenhum produto específico amplificado, f, falha na amplificação de alguns indivíduos.

Cada reação de amplificação constou de um volume total de $25 \mu 1$, contendo 50 ng de DNA genômico; $50 \mathrm{mM} \mathrm{KCl} ; 10$ mM Tris- $\mathrm{HCl} \mathrm{pH}$ 8.8; 0.1\% Triton-X; $1.5 \mathrm{mM}$ $\mathrm{MgCh} ; 100 \mu \mathrm{M}$ de cada dNTPs; $0.2 \mu \mathrm{M}$ de cada primer e 1.5 unidades de Taq polymerase (Life Technologies do Brasil, São Paulo, SP, Brasil). Amplificações foram conduzidas em termociclador Perkin Elmer modelo 9700 (Applied Biosystems, Foster City, CA, EUA), empregando-se um programa 'touchdown', com ciclo inicial de $94{ }^{\circ} \mathrm{C}$ por $3 \mathrm{~min}$, seguido $40 \mathrm{~s}$ a $94^{\circ} \mathrm{C} ; 40 \mathrm{~s}$ a $10^{\circ} \mathrm{C}$ acima da $\mathrm{Tm}$ de cada primer (Tabela 2), reduzindo um grau a cada ciclo; $60 \mathrm{~s}$ a $72{ }^{\circ} \mathrm{C}$ por $1 \mathrm{~min}$, num total de 10 ciclos, seguido de 25 ciclos de $40 \mathrm{~s}$ a $94^{\circ} \mathrm{C}, 40 \mathrm{~s}$ na Tm de cada primer (Tabela 2), e $60 \mathrm{~s} \mathrm{a} 72^{\circ} \mathrm{C}$. 


\subsubsection{Condições da eletroforese e detecção do polimorfismo}

Fragmentos microssatélites foram separados em géis de poliacrilamida desnaturante, empregando-se a metodologia proposta por Creste et al. (2001).

\subsubsection{Análise dos dados}

Fragmentos amplificados foram analisados como presença e ausência para cada loco nos 35 genótipos avaliados. A partir dos dados obtidos, foi estimada a similaridade genética entre os genótipos, utilizando-se o coeficiente de Jaccard, presente no programa NTSYS (Numerical taxonomy and Systematics, v. 1.70; Rohlf, 1992). A partir da matriz gerada, foi realizado o agrupamento dos genótipos pelo método UPGMA (unweighted pair group method) e os resultados plotados em fenograma. Análise de "bootstrap" foi realizada com 1000 reamostragens, utilizando o programa estatístico WinBoot (Yap \& Nelson, 1996).

A frequiência de heterozigotos foi calculada para cada loco com base na freqüência de indivíduos com dois ou mais alelos (Ashkenazi et al, 2001).

\subsection{Resultados}

\subsubsection{Polimorfismo de microssatélites entre genótipos de bananeira}

Um total de trinta e três pares de primers foram testados para amplificação de produtos específicos em reações de PCR, nos trinta e cinco genótipos de bananeira. No caso de ausência de amplificação, tentou-se otimizar as condições da PCR, incluindo redução da temperatura de anelamento, ajuste da concentração de $\mathrm{MgCh}$, em adição ao uso de um programa 'touchdown'. Do total, onze (33\%) pares de primers amplificaram bandas polimórficas e distintas, quatro foram monomórficos, quinze pares de primers não produziram produtos específicos e três pares de primers apresentaram falhas na amplificação de alguns indivíduos (Tabela 2). A ausência de amplificação em alguns genótipos pode refletir divergências nas seqüências que flanqueiam os microssatélites, 
produzindo alelos nulos, os quais podem se detectados após várias repetições do experimento, para garantir que não ocorreram falhas na reação.

A partir dos 11 pares de primers que produziram produtos polimórficos, 67 alelos foram obtidos, com média de 6,1 alelos por loco. O mais alto polimorfismo foi obtido com os primers Ma 3.90 e Ma 1.17 (8 alelos), e o mais baixo pelos primers Ma 3.132 e AGMI 121.122 (4 alelos). A freqüência média de heterozigotos foi 0,90 variando de 0,63 a 1,0 para cada loco de microssatélite. A Tabela 3 apresenta os resultados obtidos. A maioria das cultivares exibiu 2 ou 3 alelos ( 40 e $35 \%$ respectivamente) para cada loco. O número de alelo por genótipo variou de 1 a 2 para o indivíduo diplóide, 1 a 4 para os indivíduos triplóides e 1 a 5 para os tetraplóides. Estes números estão em concordância com aqueles reportados por Crouch et al., (1999b), suportando a hipótese da ocorrência de locos ou segmentos cromossômicos duplicados em Musa.

O primer AGMI 24/25 foi altamente informativo, capaz de discriminar o nível de ploidia de 29 (83\%) genótipos, e gerar um fingerprinting para todos os grupos genômicos. Conforme anteriormente observado por Kaemmer et al. (1997), este primer identificou um alelo (290 pb) consistentemente presente nas cultivares de genoma B, com exceção dos cultivares 'Prata Jau' e 'Terra' (Figura 1). O primer Ma 3.103 apresentou loco idêntico duplicado, identificando dois alelos (130 e $150 \mathrm{pb}$ ) capazes de discriminar genótipos com genoma 'B' (exceção 'FHIA-18' e 'Terra') e outros dois alelos (140 e 160 pb), genótipos que não apresentam o genoma 'B' (exceção 'Terra').

Houve alguns problemas na definição do tamanho exato de alguns alelos. Por exemplo, o alelo específico de genoma 'B' gerado pelo primer AGMI 24/25 é 254 pb (Kaemmer et al., 1997). No presente estudo, esse mesmo alelo foi estimado em 290 pb. Outros primers também apresentaram tamanho diferente do esperado. Conforme sugerido por Testolin et al. (2000), as possíveis causas para este problema são as condições de desnaturação durante a eletroforese, diferenças na composição em bases microssatélites, e o tipo de marcador de peso molecular ('ladder') usado como referência para medir tamanho dos alelos. 
Tabela 3. Tamanho, número de alelos e freqüência de heterozigotos de cada primer microssatélite que amplificou produtos claros e distintos.

\begin{tabular}{lccc}
\hline \multicolumn{1}{c}{ Primer } & $\begin{array}{c}\text { Variação dos } \\
\text { alelos }(\mathrm{pb})\end{array}$ & Número de alelos & $\begin{array}{c}\text { Freqüência de } \\
\text { heterozigotos }\end{array}$ \\
\hline Ma1.17 & $104-138$ & 8 & 1,00 \\
Ma 1.32 & $243-277$ & 5 & 0,63 \\
Ma 3.90 & $129-169$ & 8 & 0,87 \\
Ma3.103 & $126-160$ & 6 & 1,00 \\
Ma 3.132 & $150-186$ & 4 & 1,000 \\
Ma 3.139 & $114-141$ & 6 & 0,97 \\
Ma 3.161 & $103-141$ & 7 & 0,97 \\
AGMI 24/25 & $250-310$ & 7 & 0,87 \\
AGMI 67/68 & $186-220$ & 7 & 0,87 \\
AGMI 93/94 & $129-143$ & 5 & 0,87 \\
AGMI 121/122 & $293-350$ & 4 & 0,83 \\
Total & & 67 & 0,90 \\
Média Geral & & 6,1 & \\
\hline
\end{tabular}

\subsubsection{Relações genéticas}

A partir do fenograma obtido (Figura 2), pode-se verificar que os genótipos foram divididos em dois grandes grupos, descritos a seguir. O primeiro grupo contém todas as cultivares com genoma exclusivamente A; enquanto o segundo possui todos as cultivares resultantes da hibridização natural ou artificial entre Musa acuminata e Musa balbisiana. Um pequeno grupo uniu a cultivar triplóide 'Caipira' e a cultivar diplóide 'Lidi'. Dentro de cada grupo, a união entre os genótipos ocorreu fundamentalmente com base no nível de ploidia, grupo genômico e subgrupo. 

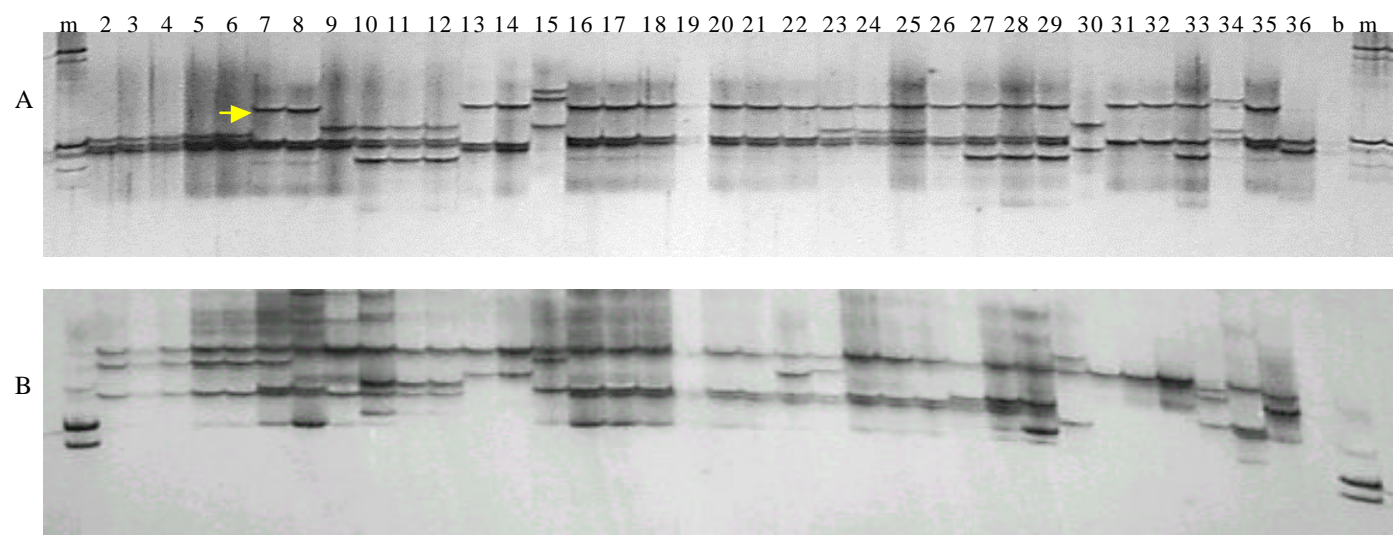

Figura 1 - Padrões de amplificação gerados pelos primer AGMI 24/25 (A) e Ma 3.90 (B). m: marcador $123 \mathrm{pb}$; 2. Williams; 3. Grande Naine; 4. Nanica; 5. Nanicão; 6. PBN; 7. Ouro da Mata; 8. Branca Santa Catarina; 9. Gros Michel; 10. Bucaneer; 11. Ambrosia; 12. Calipson; 13. Mysore; 14. Thap Maeo; 15. Prata Jau; 16. Prata; 17. Prata (Cruz das Almas); 18. Prata Santa Maria; 19. Prata Ponta Aparada; 20. Enxerto; 21. Prata Anã; 22. Pioneira; 23. FHIA-01; 24. FHIA-18; 25. SH3640; 26. Pacovan; 27. PV42-142; 28. PV42-85; 29. PV42-68; 30. Caipira; 31. Maçã; 32. Yangambi Km 2; 33- YB42-21, 34Terra, 35- Prata Porte Baixo, 36- Lidi, b- branco. A seta indica o marcador de genoma 'B'.

\subsubsection{Discriminação de genótipos pertencentes a um mesmo subgrupo}

As cultivares do subgrupo 'Cavendish' não puderam ser discriminadas, apresentando $100 \%$ de homologia. As cultivares do subgrupo Prata, 'Branca Santa Catarina' e 'Pacovan' são mutantes derivados da cultivar 'Prata', mas puderam ser discriminadas pelos primers Ma 3.161 e AGMI 121.122 respectivamente. A cultivar 'Prata Jau' não se agrupou a este subgrupo, mostrando-se bastante distanciada das demais cultivares. 'Enxerto' e 'Prata Anã' são duplicatas de um mesmo material e por isso apresentaram-se idênticas pelos marcadores ensaiados. 'Thap Maeo' compreende 


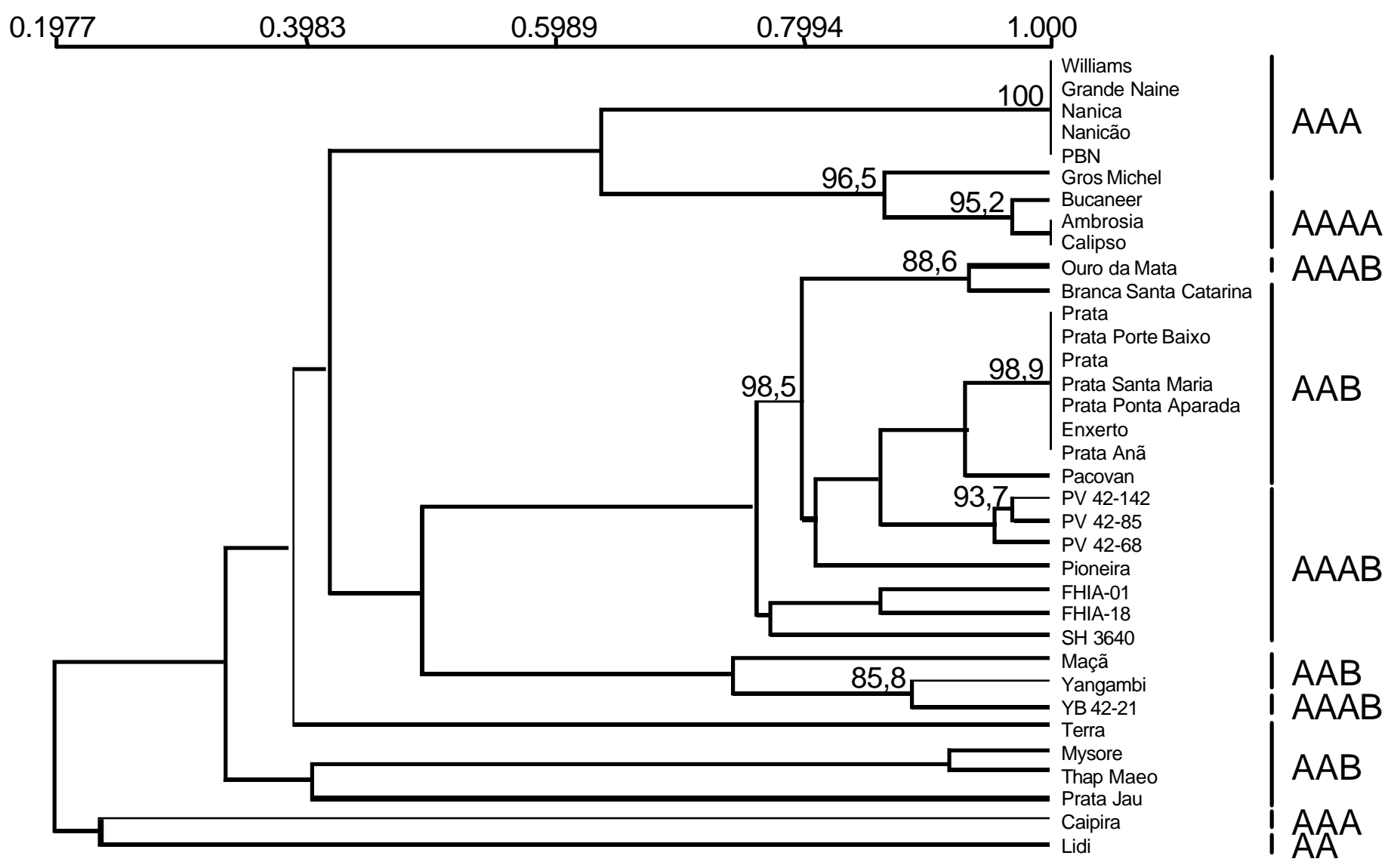

Figura 2 - Fenograma gerado pelo agrupamento UPGMA a partir de dados de similaridade pelo coeficiente de Jaccard, demonstrando as relações genéticas entre variedades de bananeira, baseado em marcadores microssatélites. Os números sobre o fenograma referem-se aos valores de "bootstrap". 
um variante de 'Mysore', que não apresenta contaminação por BSV, (Banana Streak Virus) mas foi possível discriminá-las pelo primer Ma 3.161.

\subsubsection{Discriminação de híbridos compartilhando o mesmo parental feminino.}

Os híbridos tetraplóides, compartilhando o mesmo genitor feminino, mantiveram-se próximos. Por exemplo, 'PV42-142', 'PV42-68', 'PV42-85', derivados de 'Pacovan' apresentaram alta similaridade entre eles. O mesmo foi verificado para aqueles tetraplóides derivados de 'Prata Anã', tais como 'FHIA-01', 'FHIA-18', 'SH3640' e 'Pioneira'. Os híbridos derivados de 'Gros Michel'(AAA), ‘Ambrosia' e 'Calipson', apresentaram 100\% de similaridade, mas o híbrido 'Bucaneer' foi discriminado destas duas pelo primer Ma 3.90.

\subsection{Discussão}

A análise de agrupamento, representada pelo fenograma, baseada nos polimorfismos derivados de microssatélites está em concordância com a caracterização baseada em descritores morfológicos. Os primers empregados permitiram discriminar as cultivares que apresentam só o genoma de Musa acuminata, daqueles híbridos interespecíficos entre $M$. acuminata e . balbisiana, agrupando-as com base no nível de ploidia, grupos genômicos e subgrupos. Um alto polimorfismo foi observado entre os grupos genômicos, o que possivelmente reflete a grande variabilidade existente dentro do complexo de subespécies Musa acuminata. No entanto, dentro dos subgrupos a ocorrência de polimorfismo foi bastante reduzida ou até mesmo inexistente. As cultivares do subgrupo 'Cavendish', apesar de diferirem para alguns caracteres morfológicos, não puderam ser discriminadas, apresentando $100 \%$ de similaridade. Por outro lado, as cultivares 'Branca Santa Catarina' e 'Pacovan' do subgrupo 'Prata' puderam ser discriminadas pelos primers Ma 3.161 e AGMI 121/122. Kaemmer et al. (1997), empregaram marcadores SSRs na caracterização de cultivares e espécies selvagens de Musa. Embora tenha sido possível separar os grupos genômicos, nenhum 
polimorfismo foi observado dentro do subgrupo 'Cavendish', bem como dentro das bananas de cozimento (ABB) e dos plátanos (AAB).

Em Musa, a divisão em subgrupos está relacionada a ocorrência de pequenas mutações em um clone, porém com efeito importante em seu uso e comercialização (Dantas et al., 1997). Tais mutações refletem principalmente alterações na coloração das folhas e pseudocaule, bem como mudanças no porte e vigor das plantas (Jenny et al., 1999). Porém, variações expressivas em caracteres morfológicos nem sempre refletem o mesmo grau de variações genéticas (Gawel et al., 1992). A variabilidade existente dentro de cada subgrupo é dependente principalmente do genótipo e da intensidade com que cada clone é multiplicado (Jenny et al., 1999). Altos níveis de similaridade genética são esperados entre indivíduos de um mesmo subgrupo, pois partilham uma origem comum. Portanto, a observação de um padrão monomórfico de bandas reflete a manutenção da composição alélica durante ciclos de propagação vegetativa. A capacidade de discriminar mutantes somáticos de seu clone original, empregando-se SSR tem sido estudada em outras fruteiras de propagação vegetativa. Sánchez-Scribano et al. (1999) empregaram oito marcadores SSRs na discriminação de 43 cultivares de uva de mesa. Mutantes somáticos não puderam ser discriminados por este marcador. Testolin et al. (2000) empregaram 26 marcadores SSRs na discriminação de 50 clones de pêssego, poucos mutantes somáticos puderam ser discriminados.

Em Musa, híbridos tetraplóides superiores têm sido obtidos a partir do cruzamento entre um genitor feminino triplóide $(\mathrm{AAB})$ e um diplóide portador de resistência (AA). Dessa forma, assume-se que todo o genótipo feminino está representado no híbrido tetraplóide, visto que a recombinação se dá apenas pelo genitor diplóide. No entanto, a análise dos primers evidenciou que alguns híbridos apresentaram distorções na proporção de alelos doados pelos genitores femininos. Assim, os híbridos 'SH3640', 'FHIA-18' e 'Pioneira' exibiram um alelo a menos que seu progenitor feminino 'Prata Anã' para os primers Ma 1.17, Ma 3.103 e Ma 3.139 respectivamente. Da mesma forma, o híbrido 'PV42-68' apresentou apenas um alelo para o primer AGMI 121/122, enquanto que seu progenitor feminino 'Pacovan' exibiu 3 alelos. Estes dados 
suportam a constatação de Crouch et al. (1998), sobre a ocorrência de recombinação gamética no genitor feminino triplóide.

A natureza co-dominante dos marcadores SSRs permite fazer estimativas das relações alélicas entre os indivíduos. Para tal, é necessário que o polimorfismo revelado possibilite genotipar os indivíduos. No entanto, a alta proporção de alelos multiplex revelada pelos marcadores SSRs neste estudo compromete a definição das relações alélicas entre indivíduos pertencentes a subgrupos diferentes. Este comprometimento decorre do erro no escore do polimorfismo microssatélite em espécies poliplóides, heterozigóticas, no qual cada alelo é interpretado como um único caracter, não levando em conta o efeito da dosagem de um gene (Provan et al., 1996). Dessa forma, duas cultivares triplóides, contendo apenas dois alelos, a primeira duplex para o primeiro alelo (i.e. $\mathrm{A}_{1} \mathrm{~A}_{1} \mathrm{~A}_{2}$ ) e a segunda duplex para o segundo alelo (i.e. $\mathrm{A}_{1} \mathrm{~A}_{2} \mathrm{~A}_{2}$ ) apresentam-se idênticas por marcadores SSRs, quando na realidade são apenas $66 \%$ similares. A discriminação entre as duas cultivares somente será possível se métodos que permitam estimar a dosagem alélica forem empregados, como a utilização de PCR quantitativo.

Apesar da similaridade genética refletida pelos marcadores SSRs em espécies poliplóides heterozigotas possuir baixo nível de correspondência com a real similaridade existente, a existência de alelos múltiplos ou até mesmo locos duplicados, os constitui em ferramentas valiosas para fingerprinting e discriminação varietal. Como exemplo, podemos citar o primer AGMI 24/25, o qual gerou um perfil único de bandas para cada grupo genômico estudado, como também discriminou a cultivar 'Prata Jau', sem nenhuma relação com as cultivares do subgrupo Prata. Segundo Crouch et al. (1998), o emprego de marcadores SSR em híbridos triplóides secundários apropriados para registro revelou que apenas um primer foi suficiente para gerar um fingerprinting para o novo germoplasma híbrido. Grapin et al. (1998) empregaram nove marcadores SSR na caracterização de 59 genótipos diplóides de Musa acuminata. Os primers empregados permitiram discriminar M. acuminata burmanica de M. acuminata burmanicoides como também M. a. errans de M. a. banksii, as quais mostravam-se muito semelhantes por marcadores RFLP (Carrell et al., 1994). Em batata, o emprego de 2 primers SSRs permitiu a Ashkenazi et al (2001) discriminar 12 cultivares, enquanto que Provan et 
al.(1996), discriminaram 18 cultivares com um único primer SSR. Sánchez-Scribano et al. (1999) discriminaram 43 cultivares de uva-de-mesa empregando-se 8 primers SSRs. Guilford et al. (1997) discriminaram $21 \mathrm{cv}$ de maçã com apenas 3 primers.

Em Musa, outras técnicas baseadas no polimorfismo de DNA têm sido empregadas visando a caracterização do germoplasma, discriminação de cultivar bem como na definição da composição genômica dos clones. Bhat \& Jarret (1995), caracterizaram 57 genótipos de Musa de constituição genômica AA, AAA, AB, AAB, $\mathrm{ABB}$ e $\mathrm{BB}$ empregando marcadores RAPD. Apenas 10 primers de RAPD foram suficientes para discriminar todos os genótipos, permitindo ainda diferenciar cultivares que se apresentaram idênticas pelos descritores morfológicos. Damasco et al. (1996) identificaram um marcador RAPD capaz de discriminar variantes somaclonais de 'Cavendish' apresentando a característica de nanismo. Kaemmer et al. (1992) empregaram fingerprinting de oligonucleotídeos e RAPD na caracterização de 15 genótipos de Musa, compreendendo espécies selvagens e cultivares de constituição AA, AAA, AAAA, AAB, ABB e BB, o que possibilitou aos autores identificar bandas associadas aos genomas A e B. Pillay et al. (2000), determinaram a composição genômica de 29 genótipos de Musa, empregando 3 marcadores RAPD específicos de genoma A e B por eles identificados. Estes mesmos marcadores permitiram aos autores reclassificar genótipos caracterizados erroneamente pelos descritores morfológicos. Loh et al. (2000) obtiveram um fingerprinting único para 12 das 16 cultivares de banana avaliadas, empregando 8 combinações de primers AFLP. Kamaté et al. (2001), determinaram a composição genômica de 28 taxa de $M u s a$ empregando-se citometria de fluxo. Análises com sondas RFLP citoplamáticas conduzidas por Fauré et al. (1994) em progênies diplóides evidenciaram a herança materna do DNA cloroplástico e paterna do DNA mitocondrial. 


\subsection{Conclusão}

Os 11 locos microssatélites empregados neste estudo foram capazes de discriminar a maioria das cultivares de bananeira e em alguns casos, discriminar clones de seus respectivos mutantes somáticos, cultivares erroneamente classificadas e identificar duplicatas, como verificado no subgrupo 'Prata'. 


\title{
5 VARIABILIDADE GENÉTICA EM GENÓTIPOS DIPLÓIDES DE Musa acuminata E CULTIVARES TRIPLÓIDES DE BANANEIRA REVELADA POR MARCADORES MICROSSATÉLITES.
}

\author{
S. CRESTE ${ }^{1}$; A. TULMANN-NETO ${ }^{2}$; R. VENCOVSKY ${ }^{1}$; S.O. SILVA ${ }^{3}$; A. \\ FIGUEIRA ${ }^{2}$.
}

1. Departamento de Genética - ESALQ/USP - Av. Pádua Dias, 11 CP 83, Piracicaba SP, 13400-970. Brasil.

2. Centro de Energia Nuclear na Agricultura - CENA/USP - Av. Centenário, 303, CP 96, Piracicaba - SP, 13400-970. Brasil.

3. Centro Nacional de Pesquisa em Mandioca e fruticultura - CNPMF/EMBRAPA Rua Embrapa, s/n, CP 007, Cruz das Almas - BA, 44380-000. Brasil.

Palavras-chave: Banana, microssatélite, Musa acuminata, SSRs. 


\section{Resumo}

Marcadores microssatélites foram empregados para investigar a variabilidade genética e as relações existentes em 58 genótipos de Musa, compreendendo 49 diplóides e 9 cultivares triplóides. Trinta e três pares de primers desenvolvidos para banana foram testados, dos quais nove amplificaram produtos claros e distintos, produzindo um total de 115 alelos. O número de alelos por primer variou de 10 a 15, com média de 12,77. Dois procedimentos de análise dos dados foram empregados. No primeiro, um fenograma contendo todos os genótipos foi construído a partir da matriz similaridade gerada pelos dados de presença ou ausência de um fragmento amplificado. No segundo, o tamanho de cada alelo dos indivíduos diplóides foi definido em pares de base e a medida de diversidade genética avaliada pelo parâmetro $R_{\mathrm{st}}$. Os genótipos diplóides foram os que apresentaram a maior variabilidade genética, verificada pelo grande número de alelos detectados e pela baixa similaridade entre os clones. A análise fenética agrupou as cultivares triplóides em um grupo distinto, com exceção das cultivares 'Nanica' e 'Gros Michel', as quais mostraram alta similaridade com a cultivar diplóide 'Mambee Thu'. Não foi possível separar os diplóides selvagens dos cultivados, o que evidencia uma origem comum destes materiais. Uma alta proporção de alelos e/ou locos duplicados foi observada nos genótipos diplóides e nos triplóides.

\section{Summary}

Microsattelites were used to investigate the genetic variability and relationships between 58 Musa genotypes, including 49 diploids and 9 triploid cultivars. Thirty-three primer pairs developed for banana were tested, and 9 amplified discrete and clear fragments, producing a total of 115 alleles. The average number of alleles amplified per primer was 12.7 , ranging from 10 to 15 . Two approaches were used for data analyses. In the first one, a phenogram containing all the genotypes were constructed based from a similarity matrix, generated from binary data (presence or absence of amplified band). In the second approach, the size in base pairs of each allele amplified from diploid 
individuals was determined, and the genetic diversity was estimated by the $R_{\text {st }}$ parameter. The diploid genotypes presented the largest genetic variability, demonstrated by the large number of alleles detected, and the low similarity between the clones. The phenetic analysis clustered the triploid cultivars in a separated group, with the exception of the 'Nanica' and 'Gros Michel' cultivars, which showed high similarity with the diploid cultivar Mambee Thu'. It was not possible to separate the wild genotypes from the cultivated, indicating a common origin of these genotypes. A high proportion of duplicated alleles and/or loci was observed for diploid and triploid genotypes.

\subsection{Introdução}

A banana é uma das frutas mais consumidas no mundo, sendo explorada na maioria dos países tropicais. A maioria das cultivares existentes originou-se a partir da hibridação intra ou interespecífica, de duas espécies selvagens diplóides, Musa acuminata (genoma A) e Musa balbisiana (genoma B)(Simmonds \& Shepherd, 1955), as quais ocorrem de forma endêmica em todo o sudeste da Ásia (Valmayor et al., 2000).

As primeiras bananas cultivadas foram diplóides, formas triplóides passaram a ocorrer como resultado de hibridações entre diplóides parcialmente estéreis com formas macho-férteis. Por serem mais produtivos, mais vigorosos e produzirem frutos maiores, os clones triplóides foram selecionados em preferência aos diplóides, substituindo-os em muitos locais (Sharrock, 1998). No entanto, os diplóides são indispensáveis ao melhoramento genético, pois são fontes potenciais de genes de resistência a fatores bióticos e abióticos (Silva et al., 1999).

Em todo o mundo, a cultura da banana tem enfrentado uma série de problemas relacionados à infestação de patógenos e pragas, para os quais, na ausência de variedades resistentes, o uso de pesticidas é a única forma de controle Frison et al., 1997). Avanços recentes obtidos no melhoramento genético têm demonstrado o potencial da hibridação no desenvolvimento de novas cultivares (Ortiz et al., 1998). Assim, híbridos tetraplóides promissores têm sido obtidos a partir do cruzamento de um genitor diplóide cultivado, melhorado ou selvagem, portador da característica de 
interesse, com uma cultivar triplóide estabelecida (Crouch et al., 1999b). Entretanto, no melhoramento genético, os ganhos genéticos obtidos envolvendo manipulações poliplóides são altamente dependentes da utilização adequada dos recursos genéticos disponíveis ( Ortiz et al., 1998). A definição precisa das relações genéticas existentes entre os acessos mantidos no banco de germoplasma, poderá conduzir a uma maior acurácia na predição da performance híbrida (Panter \& Allen, 1995).

Vários métodos têm sido empregados para investigar a variabilidade genética presente no germoplasma de Musa. Os descritores morfotaxonômicos foram os primeiros a serem desenvolvidos e aperfeiçoados para as bananeiras, e recentemente, 119 descritores foram definidos como norma de descrição do germoplasma de Musa (Ipgri, 1999). Entretanto, muitas características vegetativas são influenciadas por fatores ambientais, apresentam variação contínua e alto grau de plasticidade, podendo muitas vezes, não refletir a real diversidade existente (Lima et al., 2001).

O desenvolvimento e aplicação de tecnologias baseadas em marcadores moleculares, fornecem ferramentas únicas, capazes de revelar polimorfismos ao nível de seqüências de DNA, suficientes para discriminar a variação genética existente entre indivíduos e dentro de populações (Kresovich et al., 1995). Dentre os diversos marcadores existentes, os mais informativos para caracterização e avaliação da variabilidade genética em Musa são os microssatélites ou SSRs (simple sequence repeats), pois são co-dominantes, abundantes e distribuídos por todo o genoma, multialélicos, reprodutíveis e amplificados via PCR (Grapin et al., 1998). As principais desvantagens deste tipo de marcador residem no custo e no trabalho requeridos para clonar e seqüenciar fragmentos de DNA contendo microssatélites. No entanto, uma vez obtidos, podem ser disponibilizados à comunidade científica e utilizados em diferentes laboratórios de pesquisa. Recentemente, primers específicos para 71 loci foram desenvolvidos e disponibilizados para estudos em Musa (Crouch et al., 1998; Lagoda et al., 1998b). 
Com o objetivo de contribuir com a caracterização dos recursos genéticos de Musa, este trabalho objetivou:

- empregar os marcadores SSRs disponíveis para avaliar a variabilidade genética existente entre genótipos diplóides de Musa acuminata, compreendendo espécies selvagens, cultivares e híbridos melhorados;

- verificar as relações genéticas entre os clones diplóides e algumas cultivares triplóides de ampla aceitação comercial.

\subsection{Material e Métodos}

\subsubsection{Material}

\subsubsection{Material vegetal}

Os 49 genótipos diplóides empregados na avaliação do polimorfismo incluem espécies selvagens, cultivares primitivas e híbridos melhorados, mantidos no banco de germoplasma de banana da Embrapa Mandioca e Fruticultura, Cruz das Almas, BA, Brasil. As cultivares 'Nanica', 'Gros Michel', 'Prata', Pacovan', 'Caipira', 'Maçã', 'Yangambi Km 2' e 'Terra', representantes de diferentes grupos genômicos e subgrupos, foram incluídas neste estudo. Informações sobre cada genótipo encontram-se na Tabela 1.

\subsubsection{Primers microssatélites}

Um total de 33 pares de primers foram testados, dos quais 27 compreenderam a série completa da Map Pairs desenvolvida por Crouch et al., (1998) [série Ma] obtida da Research Genetics Inc. (Huntsville, AL, EUA) e 6 pares de primers desenvolvidos por Lagoda et al. (1998b) [série AGMI], sintetizados pela Life Technologies do Brasil (São Paulo, Brasil). Detalhes dos primers empregados estão listados na Tabela 2. 
Tabela 1. Lista dos 58 genótipos de Musa avaliados por marcadores microssatélites.

\begin{tabular}{|c|c|c|c|}
\hline $\begin{array}{c}\text { Grupo genômico } \\
\text { tipo }^{\text {a }}\end{array}$ & $\begin{array}{l}\text { subgrupo } \\
\text { subespécie }\end{array}$ & $\begin{array}{c}\text { clone } \\
\text { variedade }\end{array}$ & Origem \\
\hline AA (s) & malaccensis & Jambi & Indonésia \\
\hline $\mathrm{AA}(\mathrm{s})$ & malaccensis derivado & Pa Musore 2 & Tailândia \\
\hline AA (s) & siamea derivado & Pa Songlka & o.d. \\
\hline $\mathrm{AA}(\mathrm{s})$ & siamea & Pa Rayong & Tailândia \\
\hline $\mathrm{AA}(\mathrm{s})$ & & Pa Pathalung & Tailândia \\
\hline $\mathrm{AA}(\mathrm{s})$ & & P. Serum & Tailândia \\
\hline $\mathrm{AA}(\mathrm{s})$ & microcarpa & Borneo & o.d. \\
\hline AA $(s)$ & microcarpa & Microcarpa & o.d. \\
\hline AA (s) & & Perak & Malásia \\
\hline AA (s) & & Tambi & Nova Guiné \\
\hline AA (s) & & Krasan Saichon & Tailândia \\
\hline AA (s) & & 1184 & Tailândia \\
\hline $\mathrm{AA}(\mathrm{s})$ & burmannicoides & Calcutta 4 & o.d. \\
\hline $\mathrm{AA}(\mathrm{s})$ & zebrina & Zebrina & o.d. \\
\hline $\mathrm{AA}(\mathrm{s})$ & zebrina & Monyet & Indonésia \\
\hline $\mathrm{AA}(\mathrm{s})$ & zebrina & Buitenzorg & o.d. \\
\hline $\mathrm{AA}(\mathrm{s})$ & & Birmania & o.d. \\
\hline $\mathrm{AA}(\mathrm{c})$ & & Lidi & o.d. \\
\hline $\mathrm{AA}(\mathrm{c})$ & & Cici & Indonésia \\
\hline $\mathrm{AA}(\mathrm{c})$ & & Khi Maeo & o.d. \\
\hline $\mathrm{AA}(\mathrm{c})$ & & Jaran & Tailândia \\
\hline $\mathrm{AA}(\mathrm{c})$ & & Tong Dok Mak & Tailândia \\
\hline $\mathrm{AA}(\mathrm{c})$ & & Pa Abissinea & Tailândia \\
\hline $\mathrm{AA}(\mathrm{c})$ & errans derivado & Tongat & o.d. \\
\hline $\mathrm{AA}(\mathrm{c})$ & & Malbut & Nova Guiné \\
\hline $\mathrm{AA}(\mathrm{c})$ & & Sow Muk & Nova Guiné \\
\hline $\mathrm{AA}(\mathrm{c})$ & & NBF-9 & Nova Guiné \\
\hline $\mathrm{AA}(\mathrm{c})$ & banksii derivado & Niyarma Yik & Nova Guiné \\
\hline $\mathrm{AA}(\mathrm{c})$ & banksii derivado & Mambee Tuu & Nova Guiné \\
\hline $\mathrm{AA}(\mathrm{c})$ & banksii derivado & NBA-14 & Nova Guiné \\
\hline $\mathrm{AA}(\mathrm{c})$ & & Fako Fako & Nova Guiné \\
\hline $\mathrm{AA}(\mathrm{c})$ & & Pipit & Indonésia \\
\hline $\mathrm{AA}(\mathrm{c})$ & & Raja Uter & Indonésia \\
\hline $\mathrm{AA}(\mathrm{c})$ & & Madu & o.d. \\
\hline $\mathrm{AA}(\mathrm{c})$ & & Tuu Gia & Vietnan \\
\hline $\mathrm{AA}(\mathrm{c})$ & & Babi Yadefana & Nova Guiné \\
\hline $\mathrm{AA}(\mathrm{c})$ & & Berlin & Indonésia \\
\hline $\mathrm{AA}(\mathrm{c})$ & & Jari Buaya & Indonésia \\
\hline $\mathrm{AA}(\mathrm{c})$ & & Khai Nai On & Tailândia \\
\hline
\end{tabular}


Tabela 1. Lista dos 58 genótipos de Musa avaliados por marcadores microssatélites.

\begin{tabular}{|c|c|c|c|}
\hline $\begin{array}{c}\text { Grupo genômico } \\
\text { tipo a }\end{array}$ & $\begin{array}{l}\text { subgrupo } \\
\text { subespécie }\end{array}$ & $\begin{array}{c}\text { clone } \\
\text { variedade }\end{array}$ & Origem \\
\hline $\mathrm{AA}(\mathrm{c})$ & & Ouro & o.d. \\
\hline $\mathrm{AA}(\mathrm{c})$ & & SA & o.d. \\
\hline $\mathrm{AA}(\mathrm{c})$ & & $\mathrm{s} / \mathrm{n} 2$ & o.d. \\
\hline $\mathrm{AA}(\mathrm{c})$ & & Khai & Tailândia \\
\hline $\mathrm{AA}(\mathrm{c})$ & & Tjau Lagada & o.d. \\
\hline $\mathrm{AA}(\mathrm{m})$ & & $\mathrm{F}_{3} \mathrm{P}_{4}$ & Equador \\
\hline $\mathrm{AA}(\mathrm{m})$ & & $\mathrm{F}_{2} \mathrm{P}_{2}$ & Equador \\
\hline $\mathrm{AA}(\mathrm{m})$ & & M 53 & Equador \\
\hline $\mathrm{AA}(\mathrm{m})$ & & M 48 & Equador \\
\hline $\mathrm{AA}(\mathrm{m})$ & & M-61 & Equador \\
\hline $\mathrm{AAA} / \mathrm{AAB}(\mathrm{cm})$ & & Pisang Nangka & Indonésia \\
\hline $\mathrm{AAA}(\mathrm{cm})$ & Cavendish & Nanica & - \\
\hline $\mathrm{AAA}(\mathrm{cm})$ & Gros Michel & Gros Michel & - \\
\hline AAA $(\mathrm{cm})$ & - & Caipira & - \\
\hline $\mathrm{AAB}(\mathrm{cm})$ & Prata & Prata & - \\
\hline $\mathrm{AAB}(\mathrm{cm})$ & Prata & Pacovan & - \\
\hline $\mathrm{AAB}(\mathrm{cm})$ & - & Yangambi Km2 & - \\
\hline $\mathrm{AAB}(\mathrm{cm})$ & - & Maçã & - \\
\hline $\mathrm{AAB}(\mathrm{cm})$ & & Terra & - \\
\hline
\end{tabular}

Nota: ${ }^{\text {a }}$ classificação dos genótipos $(\mathrm{s})=$ selvagens; $(\mathrm{c})=\operatorname{cultivados} ;(\mathrm{m})=$ melhorados; $(\mathrm{cm})=$ cultivares comerciais, o.d. $=$ origem desconhecida.

\subsubsection{Métodos}

\subsubsection{Extração do DNA e condições da PCR}

DNA genômico foi extraído a partir de folhas jovens, empregando-se o método CTAB proposto por Doyle e Doyle (1990), e quantificado for fluorimetria (DyNA Quant 2000 Fluorometer, Amersham Biociences, Buckinghamshire, UK).

Cada reação de amplificação constou de um volume total de $20 \mu 1$, contendo 40 ng de DNA genômico; 50 mM KCl; 10 mM Tris-HCl pH 8.8; $0.1 \%$ Triton-X; 1.5 mM $\mathrm{MgCh} ; 100 \mu \mathrm{M}$ de cada dNTPs; $0.2 \mu \mathrm{M}$ de cada primer e 1.0 unidade de Taq polymerase (Life Technologies do Brasil, São Paulo, SP, Brasil). Amplificações foram 
Tabela 2. Primers testados na caracterização dos 58 genótipos de Musa spp.

\begin{tabular}{|c|c|c|c|c|}
\hline Primer & Seqüência (5'-3’) & Produto $^{\mathrm{a}}(\mathrm{pb})$ & $\operatorname{Tm}\left({ }^{\circ} \mathrm{C}\right)$ & Resultado $^{b}$ \\
\hline Ma $1 / 2$ & $\begin{array}{l}\text { gatgatggtgagaggctgata } \\
\text { ggtcggtatgggaagcacc }\end{array}$ & 142 & 58 & $\mathrm{f}$ \\
\hline Ma 1/3 & $\begin{array}{l}\text { ctgccttccattcttgctgt } \\
\text { cccgcccaaaagttaagatc }\end{array}$ & 160 & 57 & $\mathrm{np}$ \\
\hline Ma $1 / 5$ & $\begin{array}{l}\text { agatggcggagggaagag } \\
\text { ccggatccaagcttatcga }\end{array}$ & 120 & 56 & $\mathrm{f}$ \\
\hline $\mathrm{Ma} 1 / 6$ & $\begin{array}{l}\text { caagaacccaaccggtcac } \\
\text { ttgtcatcaccatccgtcatt }\end{array}$ & 139 & 57 & $\mathrm{np}$ \\
\hline Ma1/16 & $\begin{array}{l}\text { cccectttcetcttttgc } \\
\text { cececetttcetcttttgc }\end{array}$ & 150 & 58 & + \\
\hline Ma 1/17 & $\begin{array}{l}\text { aggcggggaatcggtaga } \\
\text { ggcgggagacagatggagt }\end{array}$ & 124 & 57 & + \\
\hline Ma 1/18 & $\begin{array}{l}\text { tttgcctggttgggctga } \\
\text { ccccetttcctcttttgc }\end{array}$ & 150 & 58 & $\mathrm{np}$ \\
\hline Ma 1.24 & gagcccattaagctgaaca & 172 & 56 & + \\
\hline Ma 1.27 & $\begin{array}{l}\text { ccgacagtcaacatacaataca } \\
\text { tgaatcccaagtttggtcaag } \\
\text { caaaacacatgtccccatctc }\end{array}$ & 126 & 56 & + \\
\hline Ma 1.31 & $\begin{array}{l}\text { cacagtaaacaaggaggtgatc } \\
\text { cgacagattaagattggatca }\end{array}$ & 133 & 56 & $\mathrm{np}$ \\
\hline Ma 1.32 & $\begin{array}{l}\text { ggaacaggtgatcaaagtgtga } \\
\text { ttgatcatgtgccgctactg }\end{array}$ & 187 & 58 & + \\
\hline Ma 2/3 & $\begin{array}{l}\text { ggacaatcttacccattgatc } \\
\text { cccaaactctctctccetc }\end{array}$ & 246 & 57 & $\mathrm{np}$ \\
\hline Ma 2/4 & $\begin{array}{c}\text { ctcctttgtgagctcggcatt } \\
\text { agggtccaaggaaactcctccaa }\end{array}$ & 175 & 58 & $\mathrm{np}$ \\
\hline $\mathrm{Ma} 2 / 7$ & $\begin{array}{l}\text { tgaatcccaagtttggtcaaga } \\
\text { ccaactcttgtccetcacttca }\end{array}$ & 89 & 55 & $\mathrm{np}$ \\
\hline $\operatorname{Ma} 2 / 12$ & $\begin{array}{l}\text { cgcatgetccetctaagactc } \\
\text { tccgatcttccgccaagt }\end{array}$ & 160 & 58 & $\mathrm{np}$ \\
\hline Ma 2/23 & $\begin{array}{l}\text { attcggacaatcttaccca } \\
\text { cccaaactctctccetc }\end{array}$ & 250 & 57 & $\mathrm{np}$ \\
\hline Ma 3/1 & $\begin{array}{l}\text { cacgtaaacaaggaggtgac } \\
\text { cgacagatttaagattggata }\end{array}$ & 133 & 56 & $\mathrm{np}$ \\
\hline $\mathrm{Ma} 3 / 60$ & $\begin{array}{l}\text { tggctgacaattacatgaca } \\
\text { gcggactgtggtgtgt }\end{array}$ & 133 & 56 & $\mathrm{np}$ \\
\hline Ma 3/68 & $\begin{array}{l}\text { gaatcactgatcaccactaagaa } \\
\text { ggggtttgttaccttagatatg }\end{array}$ & 244 & 57 & $\mathrm{np}$ \\
\hline Ma $3 / 90$ & $\begin{array}{l}\text { gcacgaagaggcatcac } \\
\text { ggccaaatttgatggact }\end{array}$ & 140 & 56 & + \\
\hline Ma 3/103 & $\begin{array}{l}\text { tcgcetctctttagctctg } \\
\text { tgttggaggatctgagattg }\end{array}$ & 152 & 56 & + \\
\hline Мa 3/127 & $\begin{array}{l}\text { tcgetctaatcggattatctc } \\
\text { tctccggatccaagctta }\end{array}$ & nd & 56 & $n p$ \\
\hline Ma 3/130 & $\begin{array}{l}\text { attggggacagggacgat } \\
\text { ccggatccaagcttatcga }\end{array}$ & 198 & 58 & $\mathrm{np}$ \\
\hline Ma 3/131 & $\begin{array}{l}\text { tggaaatcaaagaaggcaagtc } \\
\text { ggagctctccggatccaa }\end{array}$ & 123 & 56 & $\mathrm{np}$ \\
\hline
\end{tabular}


Tabela 2. Primers testados na caracterização dos 58 genótipos de Musa spp.

\begin{tabular}{|c|c|c|c|c|}
\hline Primer & Seqüência (5'-3') & Produto ${ }^{a}(\mathrm{pb})$ & $\operatorname{Tm}\left({ }^{\circ} \mathrm{C}\right)$ & Resultado $^{b}$ \\
\hline Ma 3/132 & $\begin{array}{l}\text { aacgcgaatgtgtgttttca } \\
\text { tccetcttcaaccaacgcac }\end{array}$ & 160 & 57 & + \\
\hline Ma 3/139 & $\begin{array}{l}\text { actgctgctctccacctcaac } \\
\text { gtcccccaagaaccatatgatt }\end{array}$ & nd & $\mathrm{Nd}$ & + \\
\hline Ma 3/161 & $\begin{array}{c}\text { aaacgtgaaacgacagcttctg } \\
\text { tccggcttcgaattgaatg }\end{array}$ & 188 & 58 & + \\
\hline AGMI 24/25 & $\begin{array}{l}\text { tttgatgtcacaatgggttcc } \\
\text { ttaaaggtgggttagcattagg }\end{array}$ & 248 & 55 & + \\
\hline AGMI 93/94 & $\begin{array}{c}\text { aacaactaggatggtaatgtgtgga } \\
\text { gatctgaggatggttctgttggag }\end{array}$ & 128 & 55 & + \\
\hline AGMI 121/122 & $\begin{array}{l}\text { cagtttggccgcttgatctt } \\
\text { ggggtcaacatgttaagttct }\end{array}$ & 333 & 48 & + \\
\hline AGMI 157/158 & $\begin{array}{l}\text { tcaagaatcgccgaattac } \\
\text { caagacgaaggaccattgatgtt }\end{array}$ & 143 & 54 & - \\
\hline AGMI 67/68 & $\begin{array}{l}\text { ataccttctcccgttcttcttc } \\
\text { tggaaacccaatcattgatc }\end{array}$ & nd & 50 & + \\
\hline AGMI 161/162 & $\begin{array}{l}\text { tgaggcggggaatcggta } \\
\text { ggcgggagacagatggagtt }\end{array}$ & nd & 50 & + \\
\hline
\end{tabular}

Nota: ${ }^{a}$ tamanho esperado do alelo amplificado de acordo com a seqüência do fragmento usado no desenho dos primers, nd = tamanho não divulgado; ${ }^{b}$ polimorfismo em cultivares de bananeira + , polimórfico; - , monomórfico; np, nenhum produto específico amplificado, f, falha na amplificação de alguns indivíduos.

conduzidas em termociclador Perkin Elmer modelo 9700 (Applied Biosystems, Foster City, CA, EUA), empregando-se um programa 'touchdown', com ciclo inicial de $94{ }^{\circ} \mathrm{C}$ por $3 \mathrm{~min}$, seguido $40 \mathrm{~s}$ a $94^{\circ} \mathrm{C} ; 40 \mathrm{~s} 10^{\circ} \mathrm{C}$ acima da $\mathrm{Tm}$ de cada primer (Tabela 2), reduzindo um grau a cada ciclo; $60 \mathrm{~s} \mathrm{a} 72{ }^{\circ} \mathrm{C}$ por $1 \mathrm{~min}$, num total de 10 ciclos, seguido de 25 ciclos de $40 \mathrm{~s} \mathrm{a} 94^{\circ} \mathrm{C}, 40 \mathrm{~s}$ na Tm de cada primer (Tabela 2), e $60 \mathrm{~s}$ a $72^{\circ} \mathrm{C}$.

\subsubsection{Condições da eletroforese e detecção do polimorfismo}

Produtos amplificados foram misturados com $10 \mu \mathrm{l}$ (1/2 do volume de reação) de tampão de desnaturação $[10 \mathrm{mM} \mathrm{NaOH} ; 0.05 \%$ xylenecyanol (p/v); $0.05 \%$ azul de bromofenol $(\mathrm{p} / \mathrm{v}) ; 20 \mathrm{mM}$ EDTA em formamida], desnaturados a $94^{\circ} \mathrm{C}$ por $3 \mathrm{~min}$, e mantidos em gelo até o carregamento no gel. Eletroforese foi conduzida em gel de 0.4 mm (6\% poliacrilamida; $7 \mathrm{M}$ uréia), em tampão TBE (89 mM Tris-base; 2 mM EDTA; 
$89 \mathrm{mM}$ ácido bórico) correndo a $60 \mathrm{~W}, 42 \mathrm{~mA}, 1500 \mathrm{~V}$ por $70-90 \mathrm{~min}$, usando uma cuba de sequenciamento SQ3 (Amersham Pharmacia Biotech). Após a eletroforese, os géis foram corados com nitrato de prata segundo a metodologia proposta por Creste et al., (2001).

\subsubsection{Análise dos dados}

Dois procedimentos foram empregados na análise dos dados. No primeiro, cada genótipo foi avaliado para presença (1) e ausência (0) de um fragmento. A partir dos dados de presença e ausência, foi estimada a similaridade genética entre os genótipos, utilizando-se o coeficiente de Jaccard, presente no programa NTSYS (Numerical Taxonomy and Systematics, v. 1.70; Rohlf, 1992). A partir da matriz gerada, foi realizado o agrupamento dos genótipos pelo método UPGMA (Unweighted pair group method) e os resultados plotados em fenograma.

A natureza codominante dos marcadores microssatélites possibilita genotipar um indivíduo a partir do padrão de bandas geradas. No entanto, a alta porcentagem de multiplex observada principalmente nos indivíduos triplóides, compromete a definição da composição alélica destes genótipos. Portanto, os marcadores microssatélites foram considerados como de natureza dominante, e as freqüências alélicas não foram calculadas.

Com o objetivo de se quantificar a variabilidade genética existente e conhecer como essa variabilidade está fracionada entre os indivíduos, os 58 genótipos foram divididos em dois grupos: o primeiro, contendo todos os genótipos triplóides e o segundo, todos os genótipos diplóides. Este último grupo foi dividido em três 'subgrupos', a saber: cultivados, selvagens e melhorados. Os efeitos dos subgrupos foram considerados fixos. A partir da matriz de similaridade gerada pelo coeficiente de Jaccard, foi estimada a similaridade média existente entre e dentro dos genótipos triplóides e diplóides.

No segundo procedimento, o tamanho de cada alelo microssatélite foi definido em pares de bases, obtendo-se estimativas da estatística $R_{\text {st }}$ (Slatkin, 1995) disponível no 
programa $R_{\text {st }}$ Calc (Goodman, 1997). Este método de análise foi desenvolvido especificamente para dados de microssatélites e permite detectar erros durante a genotipagem dos indivíduos. Portanto, os genótipos triplóides foram excluídos desta análise. A divisão em subgrupos para os genótipos diplóides também foi considerada nesta última metodologia de análise.

A frequiência de heterozigotos foi calculada para cada loco com base na freqüência de indivíduos com dois ou mais alelos (Ashkenazi et al., 2001).

\subsection{Resultados}

Um total de 33 pares de primer foi testado na avaliação do polimorfismo SSR em 58 genótipos de Musa. Destes, 15 pares (45\%) amplificaram, sendo que dois (AGMI 93/94 e Ma 1.2) produziram alelos nulos em vários indivíduos, quatro produziram um padrão confuso de amplificação, exibindo vários alelos ou um sinal muito fraco. Nove

primers produziram padrões claros e distintos, a partir dos quais 115 alelos foram identificados a partir do escore de presença (1) e ausência (0) de um fragmento amplificado. A ausência de amplificação num indivíduo foi considerada como dado perdido. O número médio de alelos por primer foi de 12,77, sendo que o mais alto polimorfismo foi observado com os primers Ma 1.17, Ma 1.24 e Ma1.32 (15 alelos), e o mais baixo polimorfismo com o primer Ma 3.103 (10 alelos). Um exemplo do polimorfismo obtido é mostrado na Figura 1.

Dos 115 alelos identificados, 14 (12\%) estiveram presentes apenas nos genótipos cultivados, enquanto que seis (5\%), presentes apenas nos genótipos selvagens. Todavia, nenhum destes alelos esteve consistentemente presente em todos os genótipos cultivados ou selvagens, não se constituindo portanto, em marcadores para presença ou ausência de sementes.

O primer Ma 3.103 revelou um alelo (aproximadamente $126 \mathrm{pb}$ ) compartilhado com a maioria dos genótipos diplóides e triplóides. 
A heterozigosidade média observada foi de 0,615 para os diplóides cultivados, 0,530 para os selvagens, 0,528 para os melhorados e 0,580 para os clones triplóides. A Tabela 3 resume os dados obtidos.

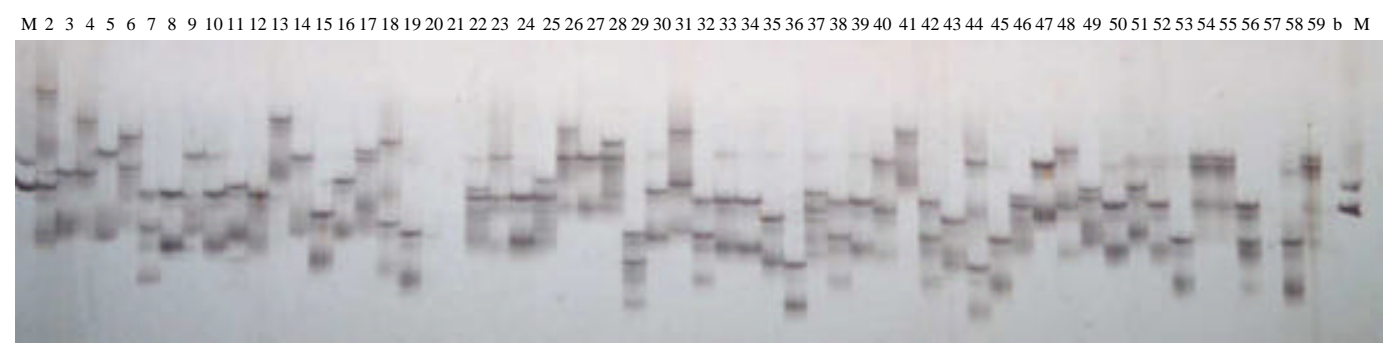

Figura 1 - Padrão de amplificação gerado pelo primer Ma 1.17. M:marcador 123pb, 2: Lidi, 3: M-53, 4: Khi Maeo, 5: Malbut, 6: Tongat, 7: Tong Dok Mak, 8: Raja Uter, 9: Niyarma Yik, 10: NBF-9, 11: Calcutta 4, 12: Madu, 13: Pa Musore 2, 14: Sow Muk, 15: No. 1184, 16: M-61, 17: NBA-14, 18: Pipit, 19: Fako Fako, 20: Perak, 21: Zebrina, 22: Tambi, 23: Babi Yadefana, 2: Jambi, 25: Pa Songkla, 26: Jaran, 27: Buitenzorg, 28: Microcarpa, 29: Khai, 30: $\mathrm{F}_{2} \mathrm{P}_{2}$, 31: Pa Pathalung, 32: Tjau Lagada, 33: Jari Buaya, 34: Cici, 35: Tuu Gia, 36: Pa Rayong, 37: Pisang Nangka, 38: Khai Nai On, 39: s/n. 2, 40: Borneo, 41: Ouro, 42: SA, 43: Birmania, 44: Pa Abissinea, 45: Berlin, 46: $\mathrm{F}_{3} \mathrm{P}_{4}, 47$ : Monyet, 48: Krasan Saichon, 49: P. Serum, 50: Mambee Tuu, 51: M-48, 52: Nanica, 53: Gros Michel, 54: Prata, 55: Pacovan, 56: Maçã, 57: Caipira, 58: Yangambi Km 2, 59: Terra, b: Branco. 
Tabela 3. Número de alelos e frequiência de heterozigotos para cada primer microssatélite que amplificou produtos claros e distintos.

\begin{tabular}{lccccc}
\hline \multirow{1}{*}{ primer } & número de alelos & $\mathrm{c}$ & $\mathrm{s}$ & $\mathrm{m}$ & $\mathrm{cm}$ \\
& & $2 \mathrm{n}$ & $2 \mathrm{n}$ & $2 \mathrm{n}$ & $3 \mathrm{n}$ \\
\hline Ma1.16 & 11 & 0,740 & 0,437 & 1,000 & 0,666 \\
Ma 1.17 & 15 & 0,666 & 0,600 & 0,600 & 0,625 \\
Ma 1.24 & 15 & 0,538 & 0,400 & 0,400 & 0,555 \\
Ma1.27 & 12 & 0,555 & 0,765 & 0,600 & 0,555 \\
Ma 1.32 & 15 & 0,730 & 0,625 & 0,400 & 0,220 \\
Ma 3.103 & 10 & 0,852 & 0,588 & 0,200 & 0,625 \\
Ma 3.139 & 11 & 0,077 & 0,353 & 0,250 & 0,750 \\
AGMI 24.25 & 14 & 0,815 & 0,687 & 0,800 & 0,714 \\
AGMI 67.68 & 12 & 0,560 & 0,308 & 0,500 & 0,500 \\
Total & 115 & & & & \\
Média Geral & 12,77 & 0,614 & 0,529 & 0,528 & 0,575 \\
\hline
\end{tabular}

Nota: $\mathrm{c}=$ cultivados $\mathrm{s}=$ selvagens $; \mathrm{m}=$ híbridos melhorados $; \mathrm{cm}=$ cultivares comerciais.

\subsubsection{Similaridade genética e análise em cluster}

A análise de similaridade a partir do coeficiente de Jaccard está representada na Figura 2. Pelo dendrograma pode-se observar que a maioria dos genótipos agrupou-se a um grupo principal a partir do qual várias ramificações ou subgrupos foram originados. Os genótipos selvagens Pa Musore 2, Birmânia, 1184 e o híbrido melhorado M-61 foram os que exibiram as menores similaridades com os genótipos do grupo principal, e por isso, mantiveram-se deslocados. As maiores similaridades foram observadas entre 'Prata' e 'Pacovan' (100\%), 'Nanica' e 'Gros Michel' (75\%) e 'Khai Nai On' e 'SA' $(76,5 \%)$. Dentro de cada subgrupo, freqüentemente houve um agrupamento de um diplóide selvagem com um diplóide cultivado ou melhorado.

Um subgrupo foi formado compreendendo todas as cultivares triplóides de constituição genômica AAB, com exceção da cultivar 'Caipira' (AAA). A esse subgrupo uniu-se, embora com baixa similaridade, a cultivar diplóide 'Tongat' e os dois híbridos 


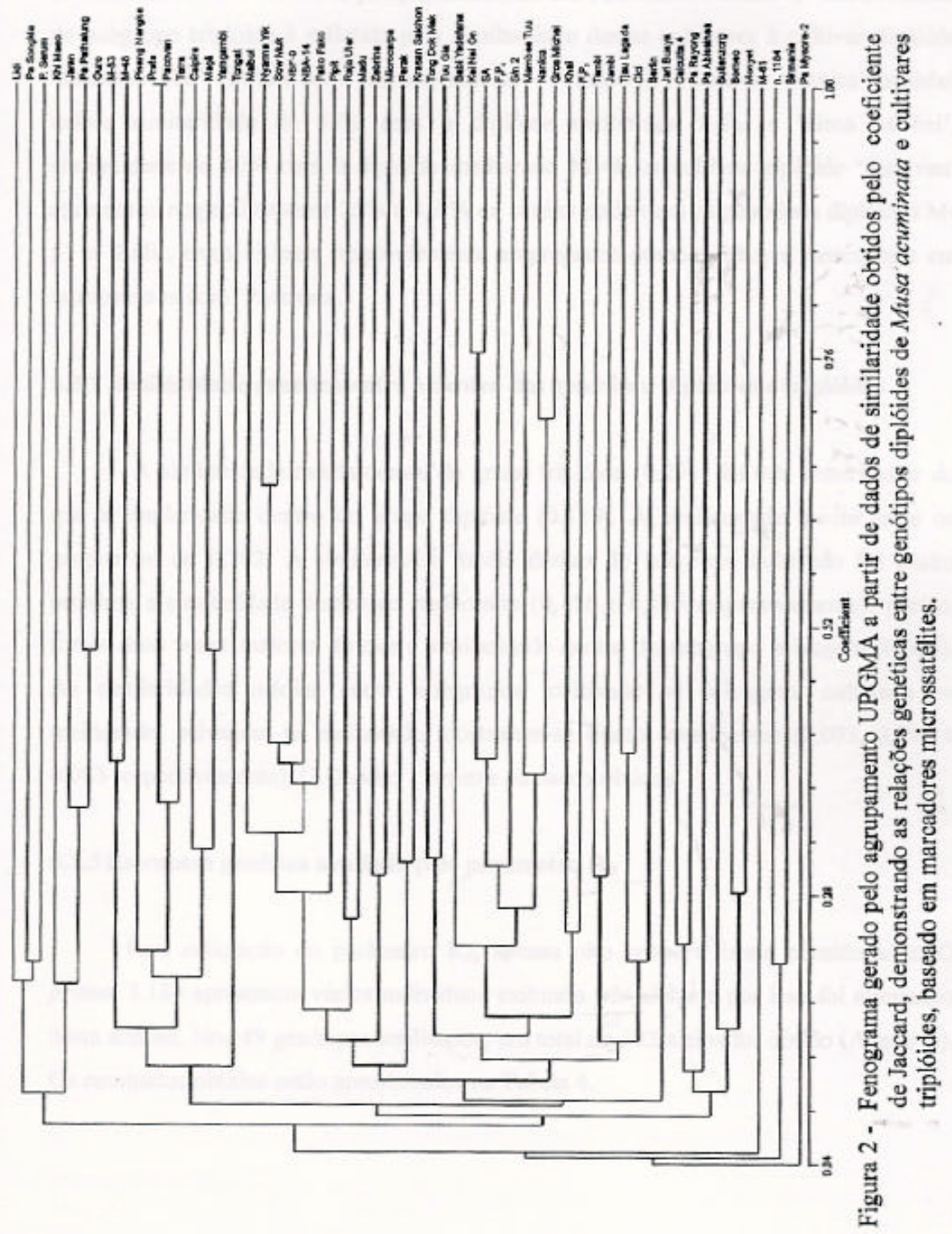


melhorados M-53 e M-48. A posição deslocada das cultivares 'Nanica' e 'Gros Michel' do subgrupo triplóide é refletida pela similaridade destas cultivares à cultivar diplóide 'Mambee Thu', (50\% e 35\% respectivamente - Anexo A). A cultivar 'Nanica' também exibiu similaridade de 44\% com o diplóide melhorado $\mathrm{F}_{3} \mathrm{P}_{4}$, e 'Gros Michel', similaridade de $40 \%$ com o diplóide melhorado M-48. A cultivar triplóide Pacovan' apresentou respectivamente $25 \%$ e 4,3\% de similaridade com os genótipos diplóides M53 e 'Lidi', estes últimos freqüentemente empregados como genitores masculinos em cruzamentos com 'Pacovan'.

\subsubsection{Similaridade genética entre e dentro dos genótipos diplóides e triplóides}

A similaridade média dentro do grupo triplóide $(0,291)$ foi três vezes maior do que a similaridade dentro do grupo diplóide $(0,110)$. A similaridade média entre os grupos foi de 0,102. A similaridade média dentro do subgrupo cultivado foi muito próxima à similaridade dentro do melhorado (0,156 e 0,140 respectivamente), porém, foram duas vezes maiores do que a similaridade dentro do subgrupo selvagem $(0,086)$. As similaridades médias entre 'subgrupos' cultivado $v s$ selvagem, cultivado $v s$ melhorado, selvagem vs melhorado mostraram-se muito semelhantes $(0,093,0,097 \mathrm{e}$ 0,083 respectivamente). O Quadro 1 resume os dados obtidos.

\subsubsection{Estrutura genética avaliada pelo parâmetro $\mathbf{R}_{\text {st }}$}

Para estimação do parâmetro $\mathrm{R}_{\mathrm{st}}$, apenas oito primers foram considerados. $\mathrm{O}$ primer 3.139 apresentou vários indivíduos exibindo três alelos e por isso foi eliminado desta análise. Nos 49 genótipos analisados, um total de 102 alelos foi obtido (Anexo B). Os resultados obtidos estão apresentados na Tabela 4. 


\begin{tabular}{|c|lcc|c|}
\cline { 2 - 4 } \multicolumn{1}{c|}{} & \multicolumn{3}{c|}{ Diplóides } & \\
\hline & $\mathrm{C}$ & $\mathrm{S}$ & $\mathrm{M}$ & $\mathrm{T}$ \\
$\mathrm{C}$ & 0,156 & 0,093 & 0,097 & 0,103 \\
$\mathrm{~S}$ & $(181)$ & $(108)$ & $(113)$ & \\
& & 0,086 & 0,083 & 0,102 \\
$\mathrm{M}$ & & $(100)$ & $(96)$ & 0,143 \\
& & & 0,140 & \\
& & & $(163)$ & 0,291 \\
\hline $\mathrm{T}$ & & 0,110 & & \\
\hline
\end{tabular}

Quadro 1 - Similaridade média entre os 58 genótipos obtida a partir da matriz de similaridade gerada pelo coeficiente de Jaccard.

Nota: $\mathrm{C}=$ cultivado; $\mathrm{S}=$ selvagem; $\mathrm{M}=$ melhorado; $\mathrm{T}=$ triplóides. Entre parênteses: valores em porcentagem, tomando a similaridade no subgrupo $\mathrm{S}(0,086)$ como 100.

Tabela 4. Estatística $R_{\text {st }}$ para os genótipos diplóides cultivados (C), selvagens (S) e melhorados (M), e respectivos intervalos de confiança (IC) a $95 \%$ de probabilidade.

\begin{tabular}{lccc}
\hline & $\mathrm{R}_{\mathrm{st}}$ & \multicolumn{2}{c}{$\mathrm{IC} 95 \%$} \\
\hline Cvs S vs M & 0,105 & 0,067 & 0,239 \\
C vs S & 0,111 & 0,056 & 0,260 \\
C vs M & 0,108 & 0,053 & 0,295 \\
S vs M & 0,112 & 0,056 & 0,318 \\
\hline
\end{tabular}

A partir destes resultados pôde-se constatar que da diversidade genética existente nos "comprimentos" dos alelos microssatélites, 10,5\% está entre os subgrupos e 89,5\% está dentro dos subgrupos. Essa diversidade alélica é de grandeza semelhante em todos os pares de grupos. 


\subsection{Discussão}

Este trabalho mostrou a utilidade dos marcadores microssatélites em investigar o nível de variabilidade genética, a distribuição desta variação e as relações genéticas existentes dentro do germoplasma de Musa. Um grande número de alelos pôde ser detectado, o que reflete a grande variabilidade genética existente, como também comprova a natureza multialélica deste tipo de marcador.

Todos os genótipos puderam ser discriminados, com exceção das cultivares 'Prata' e 'Pacovan' (mutante de 'Prata'). Tal situação era esperada, visto que dificilmente mutantes somáticos podem ser discriminados por marcadores SSR (Sanchez-Escribano et al., 1999; Testolin et al., 2000). Pelo fenograma (Figura 2) podese verificar que não foi possível obter uma perfeita separação entre os genótipos diplóides cultivados, selvagens e melhorados. Tal fato é decorrente da existência de muitos alelos comuns a esses genótipos, sendo portanto aparentados. Observa-se também a formação de um subgrupo contendo todas as cultivares triplóides de constituição genômica $\mathrm{AAB}$ ao qual se ligou a cultivar Pisang Nangka', erroneamente catalogado como AA no banco de germoplasma da Embrapa, porém com dupla classificação (AAA e AAB) pelos descritores morfológicos (Inibap, 2001). O posicionamento da cultivar 'Caipira' junto às cultivares $\mathrm{AAB}$, impede a definição da composição genômica de 'Pisang Nangka', a qual poderá ser melhor definida por meio do emprego de técnicas citogenéticas, como a hibridação in situ.

Os programas de melhoramento objetivam a produção de híbridos tetraplóides a partir do cruzamento de uma cultivar triplóide e um genótipo diplóide portador da característica de interesse (Crouch et al., 1999b). A compreensão das relações genéticas entre triplóides e diplóides promove uma melhor compreensão dos mecanismos envolvidos no processo evolutivo das bananas, que conduziu a formação das bananeiras triplóides. Assim, a partir das relações genéticas reveladas pelos marcadores moleculares, procura-se identificar os genótipos diplóides mais aparentados às cultivares triplóides, para se tentar reproduzir os clones triplóides. Dessa forma, diplóides exibindo altas similaridades aos clones triplóides podem ser submetidos a diferentes estratégias de 
melhoramento, a qual pode envolver a duplicação do genoma diplóide com colchicina, seguida ou não da hibridação com outro diplóide (Jenny et al., 1999). Neste estudo, algumas cultivares triplóides exibiram altas similaridades com genótipos diplóides. Como exemplo, pode-se destacar que 'Nanica' exibiu similaridade de $50 \%$ com a cultivar diplóide 'Mambee Thu' e 44 \% com o híbrido melhorado $\mathrm{F}_{3} \mathrm{P}_{4}$. Esta observação é extremamente valiosa para o melhoramento, visto que 'Nanica' compreende uma cultivar tipo exportação (Subgrupo Cavendish) e apresenta esterilidade feminina completa. Sugere-se portanto, que maiores apreciações sejam feitas a respeito desta relação, a fim de que novas possibilidades de melhoramento possam ser consideradas. Segundo Jenny et al. (1999) várias semelhanças morfológicas e moleculares existem entre os clones diplóides e triplóides. Sob o aspecto morfológico, vários diplóides AA assemelham-se às bananas de cozimento (plátanos), outros, o sabor e o tipo de consumo dos frutos assemelham-se aos triplóides tipo 'Maçã'. Análises RFLP conduzidas sobre os genomas citoplasmáticos e nuclear revelaram que as cultivares dos subgrupos 'Cavendish' e 'Gros Michel' possuem o mesmo perfil citoplasmático de várias cultivares AA, enquanto que alguns clones de cozimento (AAB) possuem seus genomas mitocondrial e cloroplástico idênticos à espécie Musa acuminata banksii. No entanto, algumas cultivares triplóides apresentaram origem intersubespecífica, com o genoma cloroplástico idêntico à $M$. $a$. banksii e genoma mitocondrial idêntico à $M$. $a$. zebrina (Jenny et al., 1999).

Segundo a classificação morfológica, Musa acuminata divide-se em sete subespécies: M. a. banksii, M. a. burmanica, M. a. burmanicoides, M. a. siamea, M. a. zebrina, M. a. malaccencis e M. a. microcarpa. Para estas subespécies, existe a definição de acessos derivados, os quais exibem fenótipos muito semelhantes aos holótipos mas não idênticos (Jenny et al., 1999). Pelo fenograma observa-se que os genótipos Nba 14', 'Mambee Thu' e Nyarma Yik', derivados de M. a. banksii, não foram estreitamente ralacionados. Grapin et al. (1998) avaliaram 59 genótipos diplóides de Musa acuminata e verificaram que os acessos de $M$. a. banksii apresentaram forte relação. Esta constatação também foi verificada por Jenny et al. (1999) somada a uma alta taxa de homozigose nos acessos de M. a. banksii. Diferentemente, todos os acessos 
derivados de $M$. a. banksii empregados neste estudo são cultivares, as quais mostraramse altamente heterozigóticas. Jarret et al., (1992) caracterizaram por RFLP 26 acessos representativos do gênero Musa. A análise em cluster não evidenciou uma perfeita separação das espécies $M$. a. banksii e $M$. a. malaccensis, sendo que os diplóides partenocárpicos não se agruparam de forma clara com suas respectivas subespécies progenitoras.

Os três acessos representantes de M. a. zebrina 'Buitenzorg', 'Monyet' e 'Zebrina', avaliados neste estudo, apresentaram uma relação inesperada com os acessos de M. a. microcarpa: 'Borneo' e Microcarpa'. Diferentemente, Grapin et al. (1998) verificaram estreita relação entre os três acessos de $M$. a. zebrina empregados neste estudo. É possível que tenha ocorrido um erro de identificação entre os acessos 'Zebrina' e 'Microcarpa' no banco de germoplasma.

Neste trabalho foi possível observar que alguns clones agruparam-se com base em sua origem geográfica, enquanto que em outros, nenhuma relação foi estabelecida. O mesmo foi observado por Jarret et al. (1993) na caracterização de 29 acessos diplóides de Musa acuminata, empregando primers específicos para uma região repetitiva. Segundo os mesmos autores, a impossibilidade de estabelecer uma correlação entre os genótipos analisados e sua origem geográfica pode refletir uma intervenção humana relativamente recente na dispersão destes materiais.

A natureza codominante dos marcadores microssatélites constitui uma de suas maiores vantagens, quando comparado com outros métodos baseados em PCR, pois permite fazer estimativas das relações alélicas entre os indivíduos. Para tal, é necessário que o polimorfismo revelado possibilite indentificar o genótipo de um indivíduo. No entanto, a alta proporção de alelos multiplex revelada pelos marcadores SSRs em espécies poliplóides compromete a definição das relações alélicas entre os indivíduos. Além disso, o germoplasma de Musa possui natureza genômica complexa em todos os níveis de ploidia, envolvendo muitas duplicações cromossômicas, o que resulta na perda da natureza codominante dos marcadores SSRs (Crouch et al., 1999a). Esta perda de caráter codominante tem implicações importantes na estimação das relações alélicas, as quais podem ser super ou subestimadas. É superestimada, quando por exemplo, duas 
cultivares triplóides, possuem dosagens diferentes dos mesmos alelos. Assim, considerando a primeira cultivar duplex para o primeiro alelo (i.e. $\mathrm{A}_{1} \mathrm{~A}_{1} \mathrm{~A}_{2}$ ) e a segunda, duplex para o segundo alelo (i.e. $\mathrm{A}_{1} \mathrm{~A}_{2} \mathrm{~A}_{2}$ ) ambas apresentam-se idênticas por marcadores SSRs, quando na realidade são apenas $66 \%$ similares. É subestimada se forem consideradas agora, duas cultivares tetraplóides, a primeira tetraplex para um alelo (i.e. $A_{1} A_{1} A_{1} A_{1}$ ), e a segunda, duplex para os mesmos alelos e simplex para os outros dois (i.e. $\mathrm{A}_{1} \mathrm{~A}_{1} \mathrm{~A}_{2} \mathrm{~A}_{3}$ ). Neste caso, a similaridade genética pelo coeficiente de Jaccard é de 33\%, quando na realidade é de 50\% (Provan et al. 1996).

Sabendo-se que a similaridade genética refletida por este tipo de análise possui baixo nível de correspondência com a real similaridade existente, procedimentos diferentes devem ser aplicados para a interpretação fenética dos dados microssatélites em espécies poliplóides, porém, até o momento, métodos mais apropriados não estão disponíveis.

Em genótipos diplóides, a interpretação dos dados SSRs como caracter binário também pode conduzir a uma superestimação da diversidade genética existente. Esta superestimação decorre do fato que cada alelo é interpretado de forma qualitativa como um único caráter, não levando em consideração a alta taxa mutacional destes alelos, da ordem de $10^{-3}$ a $10^{-4}$ mutações por geração (Goldstein et al., 1995). Segundo Schlötterer e Tautz (1992) os locos microssatélites estão envolvidos num processo de mutação gradativa (stepwise mutation process) no qual um alelo pode mutar em um ou dois pares de base tanto para mais como para menos. Estudos conduzidos em humanos revelaram que indivíduos mutantes diferiram de seus progenitores em apenas uma ou duas unidades de repetição (Weber e Wong, 1993).

A estatística $\mathrm{R}_{\mathrm{st}}$ (Slatkin, 1995) é uma medida de diversidade genética entre subpopulações, desenvolvida especificamente para dados microssatélite. Esta estatística considera o modelo de mutações aos saltos, no qual os alelos podem ser idênticos em estado, apenas porque a mutação agiu aumentando ou diminuindo a mobilidade eletroforética de um alelo em uma unidade (Rousset, 1996). Para estimação do parâmetro $\mathrm{R}_{\mathrm{st}}$, o genótipo de cada indivíduo é definido a partir do seu tamanho em pares de base. Apesar da existência de muitos locos duplicados nos genótipos diplóides de 
Musa, é possível, a partir da disponibilidade de um grande número de primers, escolher aqueles que amplifiquem loco único nestes genótipos, estabelecendo-se, desta forma, informações mais precisas sobre suas relações genéticas.

A natureza do processo de estimação do parâmetro $R_{\text {st }}$ permite que alguns erros de genotipagem dos marcadores microssatélites fiquem diluídos na variância da estimativa. Neste trabalho, o valor $\mathrm{R}_{\mathrm{st}}$ sob todos os locos foi de 0,105. Este valor revela a existência de muitos alelos comuns entre os subgrupos. Assim, a maior diversidade dos comprimentos dos alelos microssatélites encontra-se dentro de cada subgrupo, reduzindo a diferenciação genética entre estes subgrupos, conforme observado pelo fenograma. Estimativas similares do parâmetro $R_{\text {st }}$ têm sido encontrados em outras espécies. Gaioto (2001), obteve $\mathrm{R}_{\mathrm{st}}=0,065 \mathrm{em}$ duas populações de palmito, enquanto que Zucchi (2001) ${ }^{1}$ obteve $\mathrm{R}_{\mathrm{st}}=0,16 \mathrm{em}$ dez populações de cagaita.

\subsection{Conclusões}

A alta diversidade gênica revelada pelos marcadores microssatélites neste estudo possivelmente reflete uma alta diversidade genética dentro do germoplasma de Musa acuminata. Estes dados permitem sugerir que o material analisado é representativo da diversidade genética existente em Musa acuminata.

\footnotetext{
${ }^{1}$ Zuchi, M.I. Comunicação Pessoal, 2001.
} 


\section{CONCLUSÕES GERAIS}

As principais conclusões obtidas a partir dos resultados do presente trabalho foram:

1) A técnica de detecção do polimorfismo microssatélite empregando-se a coloração com prata mostrou-se altamente sensível, podendo ser empregada em substituição aos métodos clássicos, envolvendo a marcação radioativa ou fluorescente dos nucleotídeos;

2) O polimorfismo revelado, a estabilidade somática, bem como a consistência dos resultados obtidos com os marcadores empregados, suportam o estabelecimento de uma técnica de fingerprinting para cultivares de banana baseada nestes marcadores;

3) Os marcadores microssatélites mostraram-se eficientes na discriminação de cultivares com classificação duvidosa ('Prata Jau') e poderão ser empregados na proteção de cultivares ou híbridos patenteados;

4) As distorções na proporção dos alelos doados pelo parental triplóide em híbridos tetraplóides suportam a hipótese sobre a ocorrência de recombinação durante formação dos gametas femininos,

5) A alta proporção de alelos multiplex observada principalmente nos genótipos triplóides e tetraplóides resultou na perda do caráter co-dominante dos marcadores microssatélites, o que pode ter conduzido a uma super ou subestimação das relações genéticas entre os indivíduos,

6) O polimorfismo gerado pelos marcadores microssatélites mostraram-se úteis na revelação da variabilidade genética e na distribuição dessa variação dentro do germoplasma de Musa acuminata, 
7) Uma atenção especial deve ser dada aos genótipos diplóides que exibiram altas similaridades com as cultivares triplóides, para que novas estratégias de melhoramento possam ser consideradas,

8) Apesar do germoplasma de Musa ter exibido vários locos duplicados com os primers empregados, é possível, a partir de um grande número de primers, identificar aqueles que amplifiquem locos únicos nos indivíduos diplóides,

9) A identificação de uma série de marcadores microssatélites altamente polimórfica trará contribuições importantes no mapeamento do genoma de Musa,

10) A obtenção de primers que possam ser empregados em reações multiplex resultará numa maior otimização da análise. 
ANEXOS 
ANEXO A. Matriz de similaridade gerada pelo coeficiente de Jaccard.

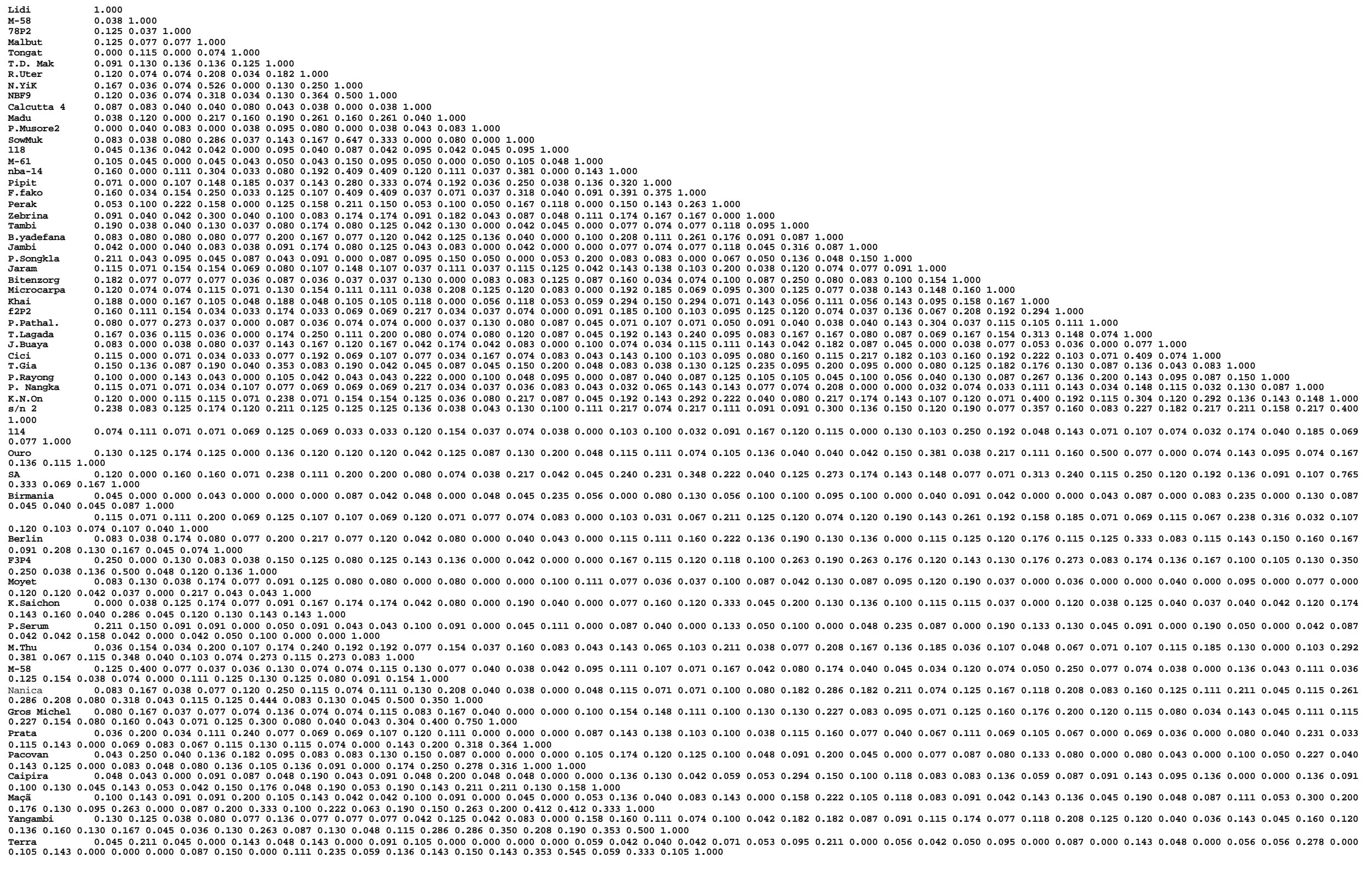


ANEXO B. Tamanho dos alelos em pares de base, para cada um dos 8 locos nos 49 genótipos de Musa acuminata.

\begin{tabular}{|c|c|c|c|c|c|c|c|c|}
\hline genótipo & Ma 1.16 & Ma 1.24 & $24 / 25$ & Ma 1.27 & Ma 1.17 & Ma 3.103 & 67.68 & Ma 1.32 \\
\hline Lidi & $146: 146$ & 171:171 & $248: 255$ & 118:118 & $126: 129$ & $126: 126$ & 110:128 & $223: 239$ \\
\hline Khi Maeo & $144: 145$ & 39:139 & $248: 248$ & $117: 117$ & $121: 129$ & $126: 132$ & 139:139 & $244: 249$ \\
\hline Malbut & $149: 152$ & $45: 145$ & $48: 269$ & $124: 124$ & $135: 135$ & $129: 130$ & $113: 113$ & $223: 239$ \\
\hline Tongat & $163: 165$ & $162: 162$ & $262: 262$ & $116: 122$ & 131:139 & $123: 130$ & $120: 120$ & $224: 224$ \\
\hline Thong Dok Mak & $144: 152$ & $135: 151$ & $248: 269$ & $116: 126$ & $115: 124$ & $126: 126$ & $120: 120$ & NA \\
\hline Raja Uter & $149: 152$ & 39:154 & $48: 251$ & $116: 126$ & $112: 124$ & $124: 129$ & 110:110 & $223: 231$ \\
\hline Niyarma Yik & $149: 152$ & $45: 160$ & $48: 269$ & $124: 124$ & $135: 135$ & $124: 131$ & 110:115 & $223: 239$ \\
\hline NBf-9 & 49:149 & $45: 160$ & $48: 260$ & $116: 124$ & $124: 124$ & $129: 131$ & & $223: 231$ \\
\hline Madu & $149: 152$ & 31:131 & $35: 262$ & & 124 & 123:129 & & $22: 223$ \\
\hline Sowmuk & $149: 152$ & $160: 160$ & $48: 269$ & $124: 124$ & $135: 135$ & $124: 131$ & 110:115 & $224: 241$ \\
\hline NBA-14 & $149: 149$ & $45: 160$ & 48:251 & $118: 124$ & 136 & $126: 129$ & 110:115 & $24: 234$ \\
\hline Pipit & $149: 153$ & $45: 160$ & $248: 262$ & $117: 122$ & $117: 139$ & 129:131 & 110:115 & $224: 244$ \\
\hline Fako-Fako & $149: 153$ & $145: 158$ & $248: 260$ & $117: 124$ & $115: 115$ & $126: 131$ & 110:115 & $224: 239$ \\
\hline Babi Yadefana & $149: 153$ & 39:139 & $251: 260$ & $126: 126$ & $124: 136$ & $126: 126$ & 114:114 & $224: 239$ \\
\hline P. Jaran & $149: 152$ & $31: 141$ & $48: 248$ & $118: 122$ & $121: 136$ & $130: 131$ & 131:131 & $236: 249$ \\
\hline Khai & $150: 150$ & $45: 145$ & 48:248 & 118:118 & 109:115 & $126: 132$ & NA & $224: 224$ \\
\hline Tjau & $50 \cdot 153$ & $39: 154$ & $48: 248$ & & & & & $1: 231$ \\
\hline Cici & & & 51 & & & & & $247: 247$ \\
\hline Jari & & & $235: 260$ & & & $124: 126$ & 114:114 & $223: 252$ \\
\hline Tuu & 52 & 51 & $48: 269$ & 129 & 19 & $126: 135$ & & $239: 239$ \\
\hline khai Na & $150: 153$ & $62: 162$ & $248: 269$ & 118:118 & 115 & $126: 131$ & $114: 130$ & $224: 247$ \\
\hline s/no. 2 & $150: 150$ & NA & $248: 255$ & $118: 126$ & $112: 124$ & $126: 130$ & $114: 123$ & $224: 239$ \\
\hline Ouro & $145 \cdot 152$ & $1: 157$ & $48: 255$ & & & 129:131 & & 249:249 \\
\hline Pa Abissinea & $152: 156$ & 62 & $48: 273$ & 27 & 36 & 130 & 11 & $223: 252$ \\
\hline SA & $149: 153$ & $62: 162$ & $248: 269$ & 118:118 & $115: 124$ & $126: 131$ & $114: 130$ & 224:244 \\
\hline Ber & & & $248: 248$ & & & & & 231:247 \\
\hline Man & 149 & & $251: 269$ & & & $130: 131$ & & $224: 231$ \\
\hline Calc & 150 & $62: 162$ & $241: 273$ & 131 & $126: 126$ & $126: 129$ & $123: 123$ & $234: 234$ \\
\hline Pa $I$ & 3 & 65 & 251 & 16 & 21 & 21 & 139:139 & 252:261 \\
\hline 1184 & $150: 152$ & $36: 151$ & $5: 277$ & 131 & 119:119 & 131 & NA & 249:249 \\
\hline Perak & $149: 152$ & $39: 139$ & NA & $117: 127$ & NA & $126: 131$ & $131: 131$ & $247: 252$ \\
\hline Zebrin & $157: 157$ & $45: 145$ & $8: 273$ & $124: 129$ & NA & $129: 129$ & & $222: 239$ \\
\hline Tambi & $149: 156$ & $54: 171$ & $248: 258$ & $120: 129$ & $124: 126$ & $123: 123$ & $128: 131$ & $241: 241$ \\
\hline Jambi & $149: 149$ & $62: 162$ & $48: 258$ & 119:120 & $112: 124$ & $135: 135$ & $147: 147$ & $247: 247$ \\
\hline & & & & & & & & NA \\
\hline Buiten & $150: 156$ & & $248: 258$ & & & $126: 130$ & NA & $234: 241$ \\
\hline Microcarpa & $152: 156$ & $165: 165$ & $248: 248$ & $118: 129$ & $136: 139$ & $129: 132$ & 110:110 & $222: 252$ \\
\hline $\mathbf{P a} \mathbf{P h}$ & & & & & & $131: 131$ & 139:139 & 249:255 \\
\hline Pa Rayong & $150: 150$ & $157: 157$ & $248: 273$ & $131: 132$ & 109:109 & $126: 126$ & NA & $252: 255$ \\
\hline Borneo & $145: 145$ & $154: 171$ & $262: 269$ & $127: 129$ & $121: 136$ & $126: 129$ & $123: 123$ & $236: 241$ \\
\hline Birm & $153: 153$ & $136: 136$ & $258: 258$ & 129:129 & 119:119 & 131:131 & $147: 147$ & $239: 264$ \\
\hline Mo & 144: & NA & $255: 255$ & 27 & 36 & $130: 135$ & $109: 113$ & $223: 223$ \\
\hline Krasan Saichon & 149:149 & 139:154 & $269: 273$ & $120: 127$ & $124: 139$ & 130:131 & NA & $241: 244$ \\
\hline
\end{tabular}


ANEXO B. Tamanho dos alelos em pares de base para cada um dos 8 locos nos 49 genótipos de Musa acuminata.

$\begin{array}{lcclccccc}\text { genótipo } & \text { Ma 1.16 } & \text { Ma 1.24 } & \mathbf{2 4 / 2 5} & \text { Ma 1.27 } & \text { Ma 1.17 } & \text { Ma 3.103 } & \mathbf{6 7 . 6 8} & \text { Ma 1.32 } \\ \text { P. Serum } & 152: 152 & \text { NA } & 206: 277 & 118: 118 & 126: 129 & 129: 132 & 128: 128 & 247: 247 \\ \text { M-53 } & 152: 163 & 141: 158 & 241: 277 & 126: 127 & 129: 129 & 123: 123 & 123: 123 & 231: 231 \\ \text { M-61 } & 153: 157 & 145: 160 & 255: 255 & 126: 126 & 128: 128 & 124: 124 & \text { NA } & 234: 234 \\ \text { F }_{2} \mathbf{P}_{2} & 156: 165 & 160: 160 & 248: 273 & 118: 127 & 115: 126 & 126: 132 & 123: 130 & 234: 244 \\ \text { F }_{\mathbf{3}} \mathbf{P}_{\mathbf{4}} & 146: 149 & 162: 162 & 248: 258 & 118: 118 & 124: 126 & 126: 126 & 114: 130 & 222: 244 \\ \text { M-48 } & 146: 156 & 160: 160 & 241: 277 & 126: 127 & 117: 129 & 126: 126 & 123: 123 & 231: 231\end{array}$

Nota: NA: não amplificou. 


\section{REFERÊNCIAS BIBLIOGRÁFICAS}

ASHKENAZI, V.; CHANI, E.; LAVI, U.; LEVY, D.; HILLEL, J.; VEILLEUX, R.E. Development of microsatellite markers in potato and their use in phylogenetic and fingerprinting analyses. Genome, v.44, p.50-62, 2001.

BASSAM, B.J.; CAETANO-ANOLLÉS, G.; GRESSHOFF, P.M. Fast and sensitive silver staining of DNA in polyacrylamide gels. Analytical Biochemistry, v.196, p.80-83, 1991.

BEIDLER, J.L.; HILLIARD, P.R.; RILL, R.L. Ultrasensitive staining of nucleic acids with silver. Analytical Biochemistry, v.126, p.374-380, 1982.

BHAT, K.V.; JARRET, R.L. Random amplified polymorphic DNA and genetic diversity in Indian Musa germplasm. Genetic Resources and Crop Evolution, v.42, p.107-118, 1995.

BLUM, H.; BEIER, H.; GROSS, H.J. Improved silver staining of plant proteins, RNA and DNA in polyacrylamide gels. Electrophoresis, v.8, p.93-99, 1987.

CARVALHO, M.T.V.; DERBYSHIRE, E.; MARTINS-CORDER, M.P.; MENDES, B.M.J.; TULMANN NETO, A. Isozyme and dissociated protein profiles of normal plants and somaclonal variants of banana obtained by in vitro culture. Acta Horticulturae, v.490, p.437-444, 1998.

CARREL, F.; FAURE, S.; DELEON, D.G.; LAGODA, P.J.L.; PERRIER, X.; BAKRY, F.; DUMONTCEL, H.T.; LANNAUD, C.; HORRY, J.P. Evaluating of the genetic diversity in diploid bananas (Musa spp). Genetics Selection Evolution, v.26, p.125-136, 1994.

CHEESMAN, J. Classification of the bananas. III. Critical notes on species. Musa paradisiaca linn. and Musa sapientum Linn. Kew Bulletin, n.2, p.145-154, 1948. 
CHRISTENSEN, M.; SUNDE, L.; BOLUND, L.; ORNTOFT, T.F. Comparison of three methods of microsatellite detection. Scandinavian Journal of Clinical and Laboratory Investigation, v.59, p.167-178, 1999.

COMINCINI, S.; LEONE, P.; REDAELLI, L.; DEGIULI, L.; ZHANG, Y.; FERRETTI, L. Characterization of bovine microsatellites by silver staining. Journal of Animal Breeding and Genetics, v.112, p.415-420, 1995.

CRESTE, S.; TULMANN-NETO, A.; FIGUEIRA, A. Detection of single sequence repeat polymorphisms in denaturing polyacrylamide sequencing gels by silver staining. Plant Molecular Biology Reporter, v.19, p.299-306, 2001.

CROUCH, H.K.; CROUCH, J.H.; JARRET, R.L.; CREGAN, P.B.; ORTIZ, R. Segregation at microsatellite loci in haploid and diploid gametes of Musa. Crop Science, v.38, p.211-217, 1998.

CROUCH, J.H.; CROUCH, H.K.; CONSTANDT, H.; VAN GYSEL, A.; BREYNE, P.; VAN MONTAGU, M.; JARRET, R.L.; ORTIZ, R. Comparison of PCR-based molecular marker analyses of Musa breeding populations. Molecular Breeding, v.5, p.233-244, 1999a.

CROUCH, J.H.; CROUCH, H.K.; TENKOUANO, A.; ORTIZ, R. VNTR-based diversity analysis of $2 \mathrm{x}$ and $4 \mathrm{x}$ full-sib Musa hybrids. Electronic Journal of Biotechnology, v.2, n.3, p.99-108, 1999b.

DAMASCO, O.P.; GRAHAM, G.C.; HENRY, R.J.; ADKINS, S.W.; SMITH, M.K.; GODWIN, I.D. Random amplified polymorphic DNA (RAPD) detection of dwarf off-types in micropropagated Cavendish (Musa spp. AAA) bananas. Plant Cell Reports, v.16, p.118-123, 1996.

DANTAS, J.L.L.; SHEPHERD, K.; SOARES FILHO, W.S. et al. Citogenética e melhoramento genético da bananeira (Musa spp.). Cruz das Almas: Embrapa, Centro Nacional de Pesquisa da Mandioca e Fruticultura, 1993. 61p (Documentos, 48) 
DANTAS, J.L.L.; SHEPHERD, K.; SILVA, S.O.; SOARES-FILHO, W.S. Classificação botânica, origem, evolução e distribuição geográfica. In: ALVES, E.J. (Ed.). A cultura da banana: aspectos técnicos, socioeconômicos e agroindustriais. Brasília: Embrapa, 1997. cap.1, p.27-34.

DEVEY, M.E.; BELL, J.C.; SMITH, D.N., NEALE, D.B.; MORAN, G.F. A genetic linkage map for Pinus radiata based on RFLP, RAPD and microsatellite markers. Theoretical and Applied Genetics, v.92, p.673-679, 1996.

DE LANGHE, E. Bananas (Musa spp.) In: FERWARDA, F.P.; WIT, F. (Ed.) Outlines of perennial crop breeding in the tropics. Wageningen: Agricultural University, 1969. p.53-78. (Miscellaneous Papers, 4)

DE LANGHE, E. Banana and plantain: the earliest fruit crops? In: INTERNATIONAL NETWORK FOR THE IMPROVEMENT OF BANANA AND PLANTAIN INIBAP. Annual report. $1995 . \quad$ p.6-8. http://www.inibap.org/publications/annualreport/focus195.pdf (dez.2001).

DE LANGHE E.; DEVREUX, M. Une sous-espèce nouvelle de Musa acuminata Colla. Bulletin du Jardin Botanique de Bruxelles, v.30, p.375-388, 1960.

D'HONT, A.; PAGET-GOY, A.; ESCOUTE, J.; CARREL, F. The interspecific genome structure of cultivated banana, Musa spp. revealed by genomic DNA in situ hybridization. Theoretical and Applied Genetics, v.100, p.177-183, 2000.

DOWLING, T.E.; MORITZ, C.; PALMER, J.D.; RIESEBERG, L.H. Nucleic Acids III: analysis of fragments and restriction sites. In: HILLIS, D.M.; MORITZ, C. MABLE, B.K. (Ed.) Molecular systematics. 2.ed. Massachusetts: Sinauer Associates, 1996. chap.8, p.249-320.

DOYLE, J.J.; DOYLE, J.L. Isolation of plant DNA from fresh tissue. Focus, v.12, p.13-15, 1990.

FAURÉ, S.; NOYER, J.L.; HORRY, J.P., BAKRY, F.; LANAUD, C.; GONZALEZ DE LEON, D. A molecular-based linkage map of diploid bananas (Musa acuminata). Theoretical and Applied Genetics, v.87, p.517-526, 1993. 
FAURÉ, S.; NOYER, J.L.; CARREEL, F.; HORRY, J.P.; BAKRY, F.; LANAUD, C. Maternal inheritance of chloroplast genome and paternal inheritance of mitochondrial genome in bananas (Musa acuminata). Current Advances in Genetics, v.25, p.265-269, 1994.

FNP Consultoria e Comércio. Agrianual: anuário da agricultura brasileira. São Paulo, 1998. p.131-138.

FNP Consultoria e Comércio. Agrianual: anuário da agricultura brasileira. São Paulo, 2001. p.194-200.

FORD-LLOYD, B.V.; HOWELL, E.; NEWBURY, H.J. An evaluation of randon amplified polymorphic DNA (RAPD) as a tool for detecting genetic instability in Musa germplasm stored in vitro. In: INTERNATIONAL SYMPOSIUM BREEDING BANANA AND PLANTAIN RESISTANCE TO DISEASES AND PESTS, Montpellier, 1992. Proceedings. Montpellier: INIBAP, 1992.

FRISON, E.A.; ORJEDA, G. SHARROCK, S.L. (Ed.) ProMusa: a global programme for Musa improvement. Montpellier: INIBAP, 1997. 64p.

GAIOTO, F.A. Inferências sobre herança quantitativa e estrutura genética em populações naturais de Euterpe edulis Mart. utilizando marcadores microssatélites. Piracicaba, 2001. 122p. Tese (Doutorado) - Escola Superior de Agricultura "Luiz de Queiroz”, Universidade de São Paulo.

GAWEL, N.J.; JARRET, R.L. Chloroplast DNA restriction fragment length polymorphisms (RFLPS) in Musa species. Theoretical and Applied Genetics, v.81, p.783-786, 1991.

GAWEL, N.J.; JARRET, R.L.; WHITTEMORE, A.P. Restriction fragment length polymorphism (RFLP)-based phylogenetic analysis of Musa. Theoretical and Applied Genetics, v.84, p.286-290, 1992.

GOLDSTEIN, D.B.; LINARES, A.R.; CAVALLI-SFORZA, L.; FELDMAN, M.W. An evaluation of genetic distances for use with microsatellite loci. Genetics, v.139, p.463-471, 1995. 
GOODMAN, S.J. R $_{\text {st }}$ Calc: a collection of computer programs for calculating estimates of genetic differentiation from microsatellite data and determining their significance. Molecular Ecology, v.6, p.881-885, 1997.

GRAPIN, A.; NOYER, J.L.; CARREEL, F.; DAMBIER, D.; BAURENS, F.C.; LANAUD, C.; LAGODA, P.J.L. Diploid Musa acuminata genetic diversity assayed with sequence-tagged microsatellite sites. Eletrophoresis, v.19, p.1374$1380,1998$.

GUILFORD, P.; PRAKASH, S.; ZHU, J.M.; RIKKERINK, E.; GARDINER, S.; BASSET, H.; FORSTER, R. Microsatellite in Malus X domestica (apple): abundance, polymorphism and cultivar identification. Theoretical and Applied Genetics, v.94, p.249-254, 1997.

HERRING, A.J.; INGLIS, N.F.; OJEH, C.K.; SNODGRASS, D.R.; MENZIES, J.D. Rapid diagnosis of rotavirus infection by direct detection of viral nucleic acid in silver-stained polyacrylamide gels. Journal of Clinical Microbiology, v.16, p.473$477,1982$.

HOWELL, E.C.; NEWBURY, H.J.; SWENNEN, R.L.; WITHERS, L.A.; FORDLLOYD, B. The use of RAPD for identifying and classifying Musa germplasm. Genome, v.37, p.328-332, 1994.

INTERNATIONAL PLANT GENETIC RESOURCES INSTITUTE - IPGRI. Descriptors for banana (Musa spp). http://198.93.227.125/descript/ banwebe.pdf (01 mar. 1999).

INTERNATIONAL NETWORK FOR THE IMPROVEMENT OF BANANA AND PLANTAIN - INIBAP. Germplasm available from INIBAP (continued). http://www.inibap.org/research/itctable2_eng.htm (dez. 2001).

JARRET, R.L.; GAWEL, N.; WHITTEMORE, A.; SHARROCK, S. RFLP-based phylogeny of Musa species in Papua New Guinea. Theoretical and Applied Genetics, v.84, p.579-584, 1992.

JARRET, R.L.; VUYLSTEKE, D.R., GAWEL, N.J.; PIMENTEL, R.B.; DUNBAR, L.J. Detecting genetic diversity in diploid bananas using PCR and primers from a highly repetitive DNA sequence. Euphytica, v.68, p.69-76, 1993. 
JEFFREYS, A.J.; WILSON, V.; THEIN, S.L. Hipervariable 'minisatellite' regions in human DNA. Nature, v.314, p.67-73, 1985.

JEFFREYS, A.J.; MACLEOD, A.; TAMAKI, K.; NEIL, D.L.; MONCKTON, D.G. Minisatellite repeat coding as a digital approach to DNA typing. Nature, v.334, p.204-209, 1991.

JENNY, C.; CARREL, F.; TOMEKPE, K.; PERRIER, X.; DUBOIS, C.; HORRY, J.P.; MONTCEL, H.T. Les bananiers. In: CENTRE DE COOPÉRATION INTERNATIONALE EN RECHERCHE AGRONOMIQUE POUR LE DÉVELOPPEMENT. Diversité génétique des plantes tropicales. Montpellier: CIRAD, 1999. p.113-129.

KAEMMER, D.; AFZA, R.; WEISING, K.; KAHL, G.; NOVAK, F.J. Oligonucleotide and amplification fingerprinting of wild species and cultivars of banana (Musa spp.) Bio/Technology, v.10, p.1030-1035, 1992.

KAEMMER, D.; FISCHER, D.; JARRET, R.L.; BAURENS, F.C.; GRAPIN, A.; DAMBIER, D.; NOYER, J.L.; LANAUD, C.; KAHL, G.; LAGODA, P.J.L. Molecular breeding in the genus Musa: a strong case for STMS marker technology. Euphytica, v.96, p.49-63, 1997.

KAMATÉ, K.; BROWN, S.; DURAND, P.; BUREAU, J.M.; DE NAY, D.; TRINH, T.H. Nuclear DNA content and base composition in 28 taxa of Musa. Genome, v.44, p.622-627, 2001.

KRESOVICH, S.; SZEWC-MCFADDEN, A.K.; BLICK, S. Abundance and characterization of simple-sequence repeats (SSRs) isolated from a size-fractionated genomic library of Brassica napus L. (rapeseed). Theoretical and Applied Genetics, v.91, p.206-211, 1995.

LAGODA, P.J.L.; DAMBIER, D.; GRAPIN, A.; BAURENS, F.C.; LANAUD, C.; NOYER, J.L. Nonradioactive sequence-tagged microsatellite site analyses: a method transferable to the tropics. Electrophoresis, v.19, p.152-157, 1998a.

LAGODA, P.J.L.; NOYER, J.L.; DABIER, D.; BAURENS, F.C.; GRAPIN, A.; LANAUD C. Sequence tagged microsatellite site (STMS) markers in the Musaceae. Molecular Ecology, v.7, p.657-666, 1998b. 
LANAUD, C.; TEZENAS DU MONTCEL, H.; JOLIVOT, M.P.; GLASZMANN, J.C.; GONZALEZ DE LEON, D. Variation of ribosomal gene spacer length among wild and cultivated banana. Heredity, v.68, p.147-156, 1992.

LITT, M.; HAUGE, X.; SHARMA, V. Shadow bands seen when typing polymorphic dinucleotide repeats: some causes and cures. BioTechniques, v.15, p.280-284, 1993.

LYSAK, M.; DOLEZELOVA, M.; DOLEZEL, J. Flow cytometric analysis of nuclear genome size in Musa spp. In: MALUSZYSKA, J. (Ed.) Plants cytogenetics. Katowice: Wydawnictwo Universytetu Slaskiego, 1998. p.178-183.

LIMA, M.L.A.; GARCIA, A.A.F.; OLIVEIRA, M.K.M.; MATSUOKA, S.; ARIZONO, H.; SOUZA-JÚNIOR, C.L.; SOUZA, A.P. Analysis of genetic similarity detected by AFLP and coefficient of parentage among genotypes of sugar cane (Saccharum spp.) Theoretical and Applied Genetics, v.103, 2001 /no prelo/

LOH, J.P.; KIEW, R.; SET, O.; GAN, L.H.; GAN, Y.Y. Amplified fragment length polymorphism fingerprinting of 16 bananas cultivars (Musa cvs.). Molecular Phylogenetics and Evolution, v.17, n.3, p.360-366, 2000.

MERRIL, C.R.; GOLDMAN, D.; SEDMAN, S.A.; EBERT M.H. Ultrasensitive stain for proteins in polyacrylamide gels shows regional variation in cerebrospinal fluid proteins. Science, v.211, p.1437-1438, 1981.

MITCHELL, S.E.; KRESOVICH, S.; JESTER, C.A.; HERNANDEZ, C.J.; SZWECMCFADDEN, A.K. Application of multiplex PCR and fluorescence-based, semiautomated allele sizing technology for genotyping plant genetic resources. Crop Science, v.37, p.617-624, 1997.

MORGANTE, M.; OLIVIERI A.M. PCR-amplified microsatellites as markers in plant genetics. The Plant Journal, v.3, p.175-182, 1993.

MORGANTE, M.; JURMAN, I.; SHI, L.; ZHU, T.; KEIM, P.; RAFALSKI, J.A. The STR 120 satellite DNA of soybean: organization, evolution and chromosomal specificity. Chromosome Research, v.5, p.363-373, 1997. 
NOVAK, F.J. Musa (banana and plantatins). In: HAMMERSCHLAG, F.A.; LITZ, R.E. (Ed.) Biotechnology of perennial fruits crops. Wellingford: CAB International, 1992. p.449-476.

ORTIZ, R.; VUYLSTEKE, D. Inheritance of black sigatoka disease resistance in plantain-banana (Musa spp.) Theoretical and Applied Genetics, v.89, p.146-152, $1994 \mathrm{a}$.

ORTIZ, R.; VUYLSTEKE, D. Inheritance of albinism in banana and plantain (Musa spp.) and its significance in breeding. HortScience, v.29, p.903-905, 1994 b.

ORTIZ, R. Musa genetics. In: GOWEN, S. (Ed.) Bananas and plantains. London: Chapman \& Hall, 1995. p.253-257.

ORTIZ, R.; VUYLSTEKE, D. Effect of the parthenocarpy gene $P_{1}$ and ploidy on fruit and bunch traits of plantain-banana hybrids. Heredity, v.75, p.460-465, 1995a.

ORTIZ, R.; VUYLSTEKE, D. Inheritance of dwarfism in plantain (Musa spp., AAB group) Plant Breeding, v.114, p.466-468, 1995 b.

ORTIZ, R.; MADSEN, S.; VUYLSTEKE, D. Classification of plantain landraces and banana cultivars using a phenotypic distance index of quantitative descriptors. Theoretical and Applied Genetics, v.96, p.904-911, 1998.

OSUJI, J.O.; HARRISON, G.; CROUCH, J.; HESLOP-HARRISON, J.S. Identification of the genome constitution of Musa L. lines (bananas, plantains and hybrids) using molecular cytogenetics. Annals of Botany, v.80, p.789-793, 1997.

PANTER, D.M.; ALLEN, F.L. Using best linear unbiased predictions to enhance breeding for yield in soybean. II. Selection of superior crosses from a limited number of yield trials. Crop Science, v.35, p.405-410, 1995.

PILLAY, M.; NWAKANMA, D.C.; TENKOUANO, A. Identification of RAPD markers linked to A and B genome sequences in Musa L. Genome, v.43, p.763$767,2000$.

POWELL, W.; MORGANTE, M.; MCDEVITT, R.; VENDRAMIN, G.G.; RAFASLKI, J.A. Polymorphic simple sequence repeat regions in chloroplast genomes: applications to population genetics of pines. Proceedings of the National Academy of Science of the USA, v.92, p.7759-7763, 1995. 
PROVAN, J.; POWELL, W.; WAUGH, R. Microsatellite analysis of relationships within cultivated potato (Solanum tuberosum) Theoretical and Applied Genetics, v.92, p.1078-1084, 1996.

RAJORA, O.P.; RAHMAN, M.H.; BUCHERT, G.P.; DANCIK, B.P. Microsatellite DNA analysis of genetic effects of harvesting in old-growth eastern white pine (Pinus strobus) in Ontario. Molecular Ecology, v.9, p.339-348, 2000.

ROHLF, F.J. NTSYSpc: numerical taxonomy and multivariate analysis system, version 2.0 user guide. New York: University of New York, Department of Ecology and Evolution State, 1992.

ROUSSET, F. Equilibrium values of measure of population subdivision for stepwise mutation process. Genetics, v.142, p.1357-1362, 1996.

SÁNCHEZ-ESCRIBANO, E.M.; MARTIN, J.P.; CARRENO, J.; CENIS, J.L. Use of sequence-tagged microsatellite site markers for characterizing table grape cultivars. Genome, v.42, p.87-93, 1999.

SANGUINETTI, C.J.; DIAS-NETO, E.; SIMPSON A.J.G. Rapid silver staining and recovery of PCR products separated on polyacrylamide gels. Biotechniques, v.17, p.915-919, 1994.

SANTOS, F.R.; PENA, S.D.J.; EPPLEN, J.T. Genetic and population study of a Ylinked tetranucleotide repeat DNA polymorphism with a simple non-isotopic technique. Human Genetics, v.90, p.655-656, 1993.

SCHLÖTTERER, C; TAUTZ, D. Slippage synthesis of simple sequence DNA. Nucleic Acids Research, v.20, p.211-215, 1992.

SHARROCK, S. Collecting the Musa gene pool in Papua New Guinea. In: GUARINO, L.; RAO, V.R.; REID, R. (Ed.) Collecting plant genetic diversity. Wallingford: CAB International, 1998. cap.33, p.647-658.

SHARROCK, S.; LUSTY, C. Nutritive value of banana. http://www.inibap.org/publications/annualreport/focus299.pdf (dez. 2001). 
SILVA, S.O.; SHEPHERD, K.; DANTAS, J.L.L.; SOUZA, A.S.; CARNEIRO, M.S. Germoplasma. In: ALVES, E.J. (Ed.) A cultura da banana: aspectos técnicos, socioeconômicos e agroindustriais. Brasília: Embrapa, 1997. cap.4, p.61-84.

SILVA, S.; MATOS, A.P.; ALVES, E.J. Melhoramento genético da bananeira. Pesquisa Agropecuária Brasileira, v.35, p.693-703, 1998.

SILVA, S.O.; ALVES, É.J.; LIMA, M.B.; SILVEIRA, J.R.S. Melhoramento genético da bananeira. In: BRUCKNER, C. H. (Ed.) Melhoramento de espécies frutíferas. Viçosa: UFV, 1999. cap.1

SIMMONDS, N.W.; SHEPHERD, K. The taxonomy and origins of the cultivated bananas. Linnean Society. Botanical Journal, v.55, p.302-312, 1955.

SIMMONDS, N.W. Los plátanos. Barcelona: Blume, 1973. 539p.

SIMMONDS, N.W. Bananas. In: SMARTT, J.; SIMMONDS, N.W. (Ed.) Evolution of crop plants. Essex: Longman, 1995. p.370-375.

SIMMONDS, N.W.; WHEATHERUP, T.C. The taxonomy and origins of cultivated bananas (Musa) New Phytologist, v.115, p.567-571, 1990.

SLATKIN, M. A measure of population subdivision based on microsatellite allele frequencies. Genetics, v.139, p.457-462, 1995.

SOMMERVILLE, L.L.; WANG, K. The ultrasensitive silver protein stain also detect nanograms of nucleic acids. Biochemical and Biophysical Research Communication, v.102, p.530-548, 1981.

STAUB, J.E.; SERQUEN, F.C.; GUPTA, M. Genetic markers, map construction, and their application in plant breeding. HortScience, v.31, p.729-740, 1996.

STOVER, R.H.; SIMMONDS, N.W. Bananas. 3.ed. New York: Longman Scientific \& Technical, 1987. 468p.

TAUTZ, D. Hypervariability of simple sequences as a general source of polymorphic markers. Nucleic Acids Research, v.17, p.6463-6471, 1989.

TESTOLIN, R.; MARRAZZO, T.; CIPRIANI, G.; QUARTA,R.; VERDE, I.; DETTORI, M.T.; PANCALDI, M.; SANSAVINI, S. Microsatellite DNA in peach (Prunus persica L. Batsch) and its use in fingerprinting and testing the genetic origin of cultivars. Genome, v.43, p.512-520, 2000. 
THOMAS, M.R.; SCOTT. N.S. Microsatellite repeats in grapevine reveal DNA polymorphisms when analysed as sequence-tagged sites (STSs). Theoretical and Applied Genetics, v.86, p.985-990, 1993.

VALDES, A.M.; SLATKIN, M.; FREIMER, N.B. Allele frequencies at microsatellite loci: the stepwise mutation model revisited. Genetics, v.133, p.737-749, 1993.

VALMAYOR, R.V.; SILAYOI, B.; JAMALUDDIN, S.H.; KUSUMO, S.; ESPINO, R.R., PASCUA, O.C. Banana classification and commercial cultivars in Southeast Asia. Los Baños: INIBAP, 1991. (PCARRD. Information Bulletin, 24) VALMAYOR, R.V.; JAMALUDDIN, S.H.; SILAYOI, B.; KUSUMO, S.; DANH, L.D.; PASCUA, O.C.; ESPINO, R.R.C. Banana cultivar names and synonyms in Southeast Asia. Los Baños: INIBAP, 2000. 24p.

VAN DE VEN, W.T.G.; MCNICOL, R.J. Microsatellites as DNA marker in Stika spruce. Theoretical and Applied Genetics, v.93, p.613-617, 1996.

VUYLSTEKE, D.; SWENNEN, R.; DELANGHE, E. Somaclonal variation in plantains (Musa spp. AAB group) derived from shoot tip culture. Fruits, v.46, p.429-439, 1991.

VUYSTEKE, D. Strategies for utilization of genetic variation in plantain improvement. Leuven, .2001. 213p. Thesis (Ph.D.) - Katholieke Universiteit Leuven.

WANG, Z.; WEBER, J.L.; ZHONG, G.; TANKSLEY, S.D. Survey of plant short tandem repeats. Theoretical and Applied Genetics, v.88, p.1-6, 1994.

WEBER, J.L.; WONG, C. Mutation of human short tandem repeats. Human Molecular Genetics, v.2, p.1123-1128, 1993.

WEISING, K.; WINTER, P.; HUTTEL,B.; KAHL, G. Microsatellite markers for molecular breeding. Journal of Crop Production, v.1, p.113-143, 1998.

YAP, I.V.; NELSON, R.J. WinBoot: a program for performing bootstrap analysis of binary data to determine the confidence limits of UPGMA-based dendrograms. Manila: International Rice Research Institute - IRRI, 1996. 22p. (Discussion paper series, 14) 